\title{
Sequence Stratigraphy: Methodology and Nomenclature
}

\author{
Octavian Catuneanu1', William E. Galloway², Christopher G. St. C. Kendall'3, \\ Andrew D. Miall ${ }^{4}$, Henry W. Posamentier ${ }^{5}$, André Strasser ${ }^{6}$, \\ and Maurice E. Tucker ${ }^{7}$
}

\begin{abstract}
The recurrence of the same types of sequence stratigraphic surface through geologic time defines cycles of change in accommodation or sediment supply, which correspond to sequences in the rock record. These cycles may be symmetrical or asymmetrical, and may or may not include all types of systems tracts that may be expected within a fully developed sequence. Depending on the scale of observation, sequences and their bounding surfaces may be ascribed to different hierarchical orders.

Stratal stacking patterns combine to define trends in geometric character that include upstepping, forestepping, backstepping and downstepping, expressing three types of shoreline shift: forced regression (forestepping and downstepping at the shoreline), normal regression (forestepping and upstepping at the shoreline) and transgression (backstepping at the shoreline). Stacking patterns that are independent of shoreline trajectories may also be defined on the basis of changes in depositional style that can be correlated regionally. All stratal stacking patterns reflect the interplay of the same two fundamental variables, namely accommodation (the space available for potential sediment accumulation) and sediment supply. Deposits defined by specific stratal stacking patterns form the basic constituents of any sequence stratigraphic unit, from sequence to systems tract and parasequence. Changes in stratal stacking patterns define the position and timing of key sequence stratigraphic surfaces.

Precisely which surfaces are selected as sequence boundaries varies as a function of which surfaces are best expressed within the context of the depositional setting and the preservation of facies relationships and stratal stacking patterns in that succession. The high degree of variability in the expression of sequence stratigraphic units and bounding surfaces in the rock record means ideally that the methodology used to analyze their depositional setting should be flexible from one sequence stratigraphic approach to another. Construction of this framework ensures the success of the method in terms of its objectives to provide a process-based understanding of the stratigraphic architecture. The purpose of this paper is to emphasize a standard but flexible methodology that remains objective.
\end{abstract}

Key words. sequence stratigraphy, stratal stacking patterns, accomodation, sediment supply, shoreline trajectories

\footnotetext{
Authors' addresses:

1 Department of Earth and Atmospheric Sciences, University of Alberta, 1-26 Earth Sciences Building, Edmonton, Alberta, T6G 2E3, Canada.

2 Institute for Geophysics, The University of Texas at Austin, Austin, Texas 78758-4445, USA.

3 Department of Geological Sciences, University of South Carolina, Columbia, South Carolina 29208, USA.

4 Department of Geology, University of Toronto, Toronto, Ontario, M5S 3B1, Canada.

5 Chevron Energy Technology Company, 1500 Lousiana Street, Houston, Texas 77382, USA.

6 Department of Geosciences, University of Fribourg, CH-1700 Fribourg, Switzerland.

7 Department of Earth Sciences, Durham University, Durham DH1 3LE, UK.
} 


\section{Part one - Concepts}

\section{Introduction}

\section{Definition of sequence stratigraphy}

Sequence stratigraphy is a methodology that provides a framework for the elements of any depositional setting, facilitating paleogeographic reconstructions and the prediction of facies and lithologies away from control points. This framework ties changes in stratal stacking patterns to the responses to varying accommodation and sediment supply through time. Stratal stacking patterns enable determination of the order in which strata were laid down, and explain the geometric relationships and the architecture of sedimentary strata. The sequence stratigraphic framework also provides the context within which to interpret the evolution of depositional systems through space and time. This analysis is improved by integration of process sedimentology with an understanding of the geometries and scales of the component depositional elements (e.g., Sprague et al. 2002).

The main tool used in sequence stratigraphic analysis is the stacking pattern of strata and the key surfaces that bound successions defined by different stratal stacking patterns. Trends in geometric character, which combine to define stratal stacking patterns, include upstepping, forestepping, backstepping, and downstepping. A sequence stratigraphic framework may consist of three different types of sequence stratigraphic unit, namely sequences, systems tracts, and parasequences. Each type of unit is defined by specific stratal stacking patterns and bounding surfaces. The definition of these units is independent of temporal and spatial scales, and of the mechanism of formation.

Concepts that are precursors to modern sequence stratigraphy arose originally as an approach to the mapping of the North American continental interior, when some generalizations about regional unconformities became apparent (e.g., Sloss et al. 1949; Sloss 1963). Subsequently, this method of stratigraphic analysis has developed into the fundamental approach for interpreting and predicting the distribution of sediment bodies. Unlike the analytical stratigraphic methods of lithostratigraphy and biostratigraphy that involve subdivisions as objectively free of interpretation as possible, sequence stratigraphy is a genetic, process-based analytical approach to stratigraphic interpretation that of necessity involves conceptual depositional models.

\section{Rationale: the need for formalization}

In spite of its popularity among geoscientists in academia, industry and government organizations, sequence stratigraphy remains a method that has no formalized definitions in stratigraphic guides or codes. This reflects

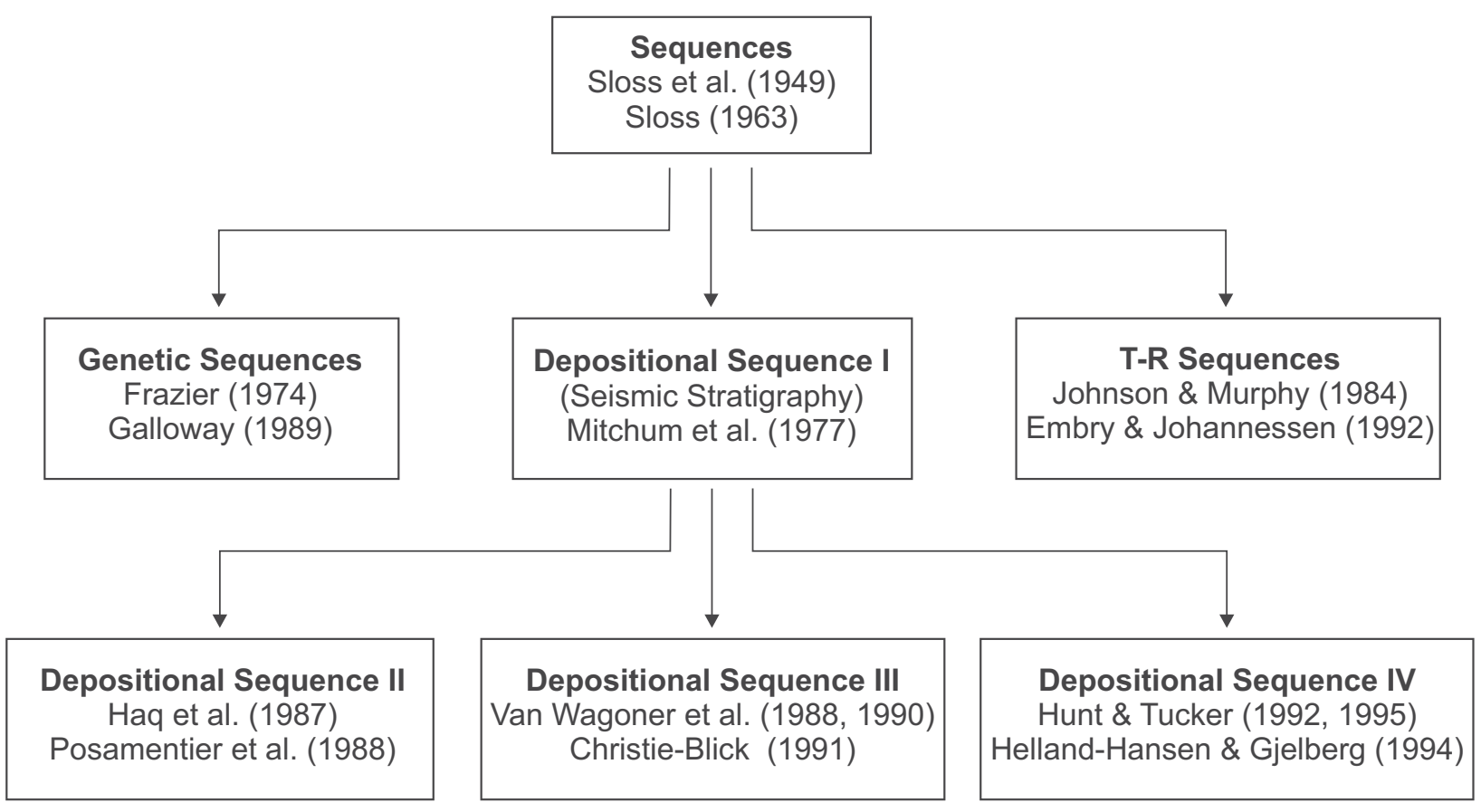

Fig. 1. Evolution of sequence stratigraphic approaches (from Catuneanu et al. 2010). 

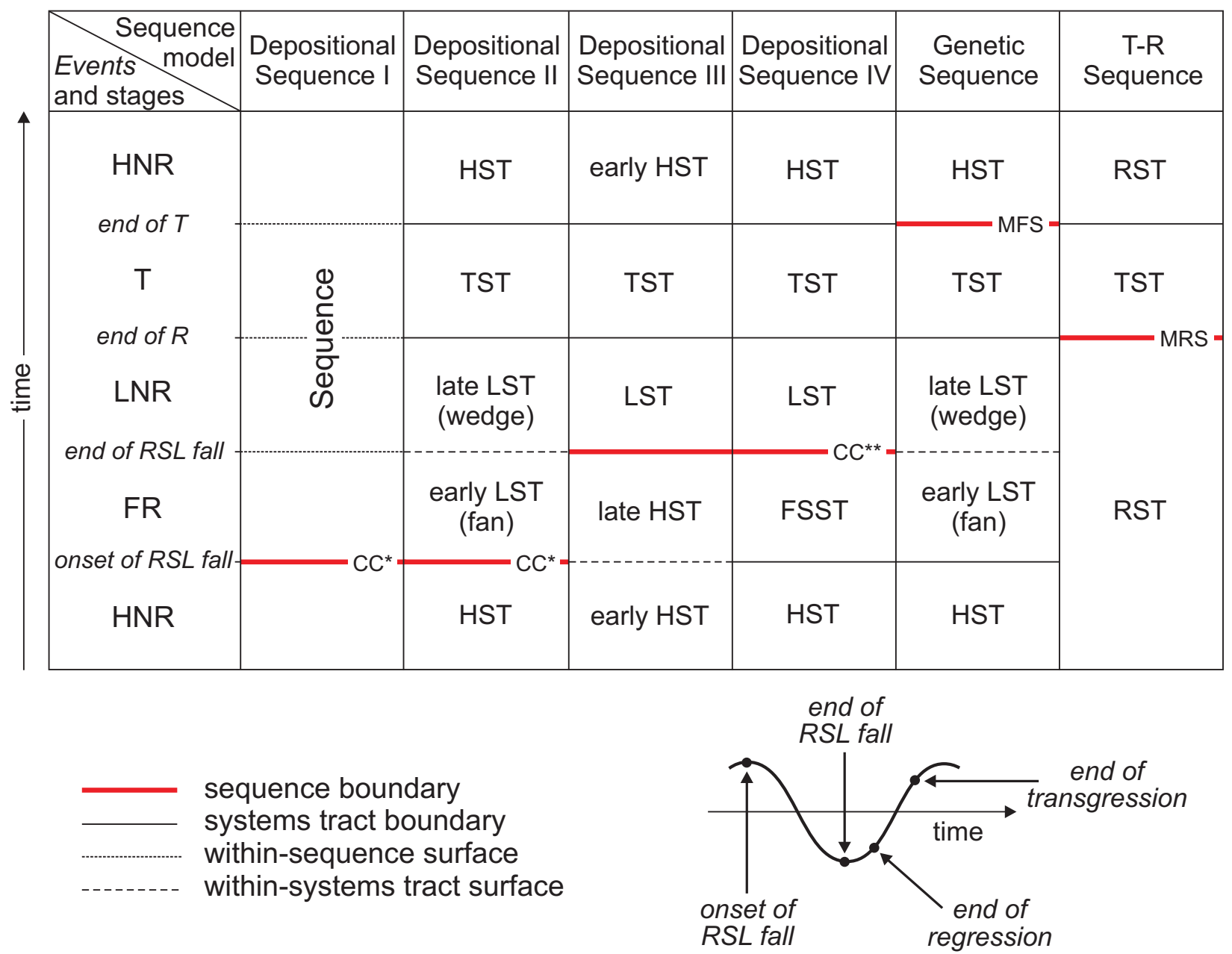

Fig. 2. Nomenclature of systems tracts, and timing of sequence boundaries for the various sequence stratigraphic approaches (modified from Catuneanu et al. 2010). Abbreviations: RSL - relative sea level; T - transgression; R - regression; FR - forced regression; LNR - lowstand normal regression; HNR - highstand normal regression; LST - lowstand systems tract; TST - transgressive systems tract; HST - highstand systems tract; FSST - falling-stage systems tract; RST - regressive systems tract; T-R - transgressive-regressive; $\mathrm{CC}^{*}$ - correlative conformity in the sense of Posamentier and Allen (1999); CC ** - correlative conformity in the sense of Hunt and Tucker (1992); MFS - maximum flooding surface; MRS maximum regressive surface. References for the proponents of the various sequence models are provided in Figure 1.

the existence of a variety of alternative approaches (Figs. 1, 2). Researchers usually choose the conceptual model that is best adapted to the depositional system they are studying, which naturally has led to a multitude of different definitions of the sequence stratigraphic units and surfaces. Such differences revolve largely around nomenclatural preferences and arguments with respect to which stratigraphic surfaces hold the greatest utility to be elevated in importance to the rank of sequence boundary. Otherwise, all approaches share a common ground that justifies the formalization of sequence stratigraphy (Catuneanu et al. 2009, 2010).

Formalization is necessary if the present state of methodological and nomenclatural confusion is to be eliminated along with the uncoordinated effort in the development of the method. Sequence stratigraphy requires the definition of a model-independent methodology that honors the various approaches but transcends their differences. A single set of terms is required so as to facilitate communication, but in no way is formalization meant to be an obstacle that limits further conceptual development or prevents certain approaches to specific situations. The definition of the common ground in sequence stratigraphy should promote flexibility with respect to the choice of approach that is best suited to a specific set of conditions as defined by tectonic setting, depositional setting, data available, and scale of observation. 


\section{Basic concepts}

\section{Accommodation}

The concept of 'accommodation' defines the space available for sediments to fill (Jervey 1988). Accommodation may be modified by the interplay between various independent controls which may operate over a wide range of temporal scales. Marine accommodation is controlled primarily by basin tectonism and global eustasy, and, over much shorter time scales, by fluctuations in the energy flux of waves and currents. Changes in marine accommodation are referred to as relative sea-level changes, when emphasis is placed on the interplay of tectonism and eustasy, or as base-level changes, when the energy flux of the depositional setting is also considered. Fluvial accommodation responds to changes in marine accommodation within the downstream portion of fluvial systems, and to changes in discharge, gradient and sediment supply that may be controlled by climate and/or source area tectonism within the upstream portion of fluvial systems. As they respond to independent controls, coastal (marine) and inland accommodation in fluvial systems may be out of phase (e.g., Blum and Tornqvist 2000).

Depositional trends of aggradation, erosion, progradation and retrogradation may be explained by changes in accommodation or by the interplay between accommodation and sediment supply. Positive accommodation promotes sediment aggradation, whereas negative accommodation results in downcutting. During stages of positive accommodation, sediment supply in excess

\section{Forced regression}

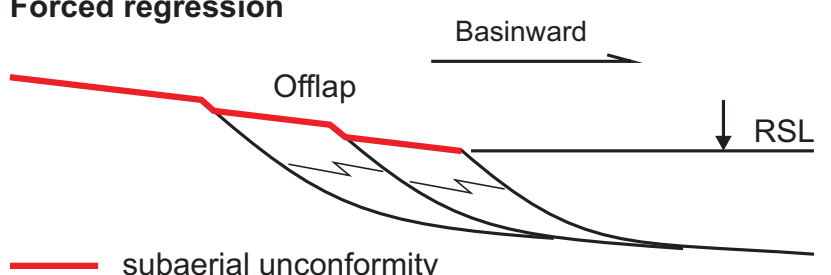

Stacking pattern: progradation with downstepping

Interpretation: progradation driven by relative sealevel fall (negative accommodation). The coastline is forced to regress, irrespective of sediment supply.

\section{Normal regression}

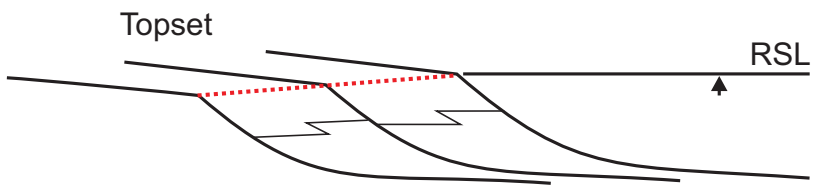

shoreline trajectory

\section{Stacking pattern: progradation with aggradation}

Interpretation: progradation driven by sediment supply. Sedimentation rates outpace the rates of relative sealevel rise (positive accommodation) at the coastline.

\section{Transgression}

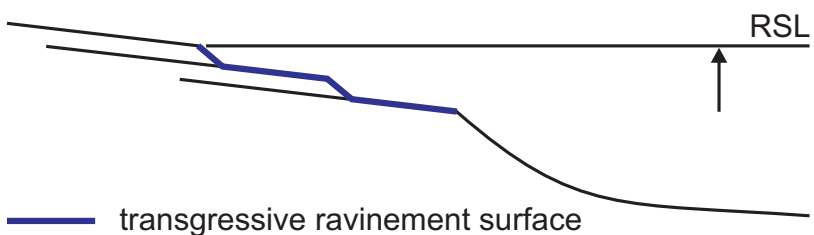

Stacking pattern: retrogradation.

Interpretation: retrogradation (backstepping) driven by relative sea-level rise. Accommodation outpaces the sedimentation rates at the coastline.

Fig. 3. Stratal stacking patterns related to shoreline trajectories (from Catuneanu et al. 2010): forced regression, normal regression, transgression. Zigzag lines indicate lateral changes of facies within individual sedimentary bodies. The diagram shows the possible types of shoreline trajectory during changes (rise or fall) in relative sea level. During a stillstand of relative sea level (not shown), the shoreline may undergo sediment-driven progradation (normal regression, where the topset is replaced by toplap), erosional transgression, or no movement at all. However, due to the complexity of independent variables that interplay to control relative sea-level change, it is unlikely to maintain stillstand conditions for any extended period of time. Abbreviation: RSL - relative sea level. 


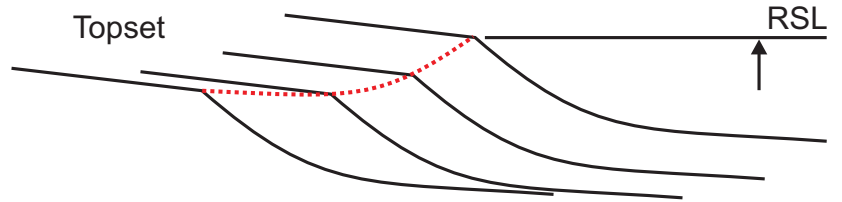

shoreline trajectory (concave up)
The rates of progradation decrease with time, the rates of aggradation increase with time.

Highstand normal regression (decelerating RSL rise)

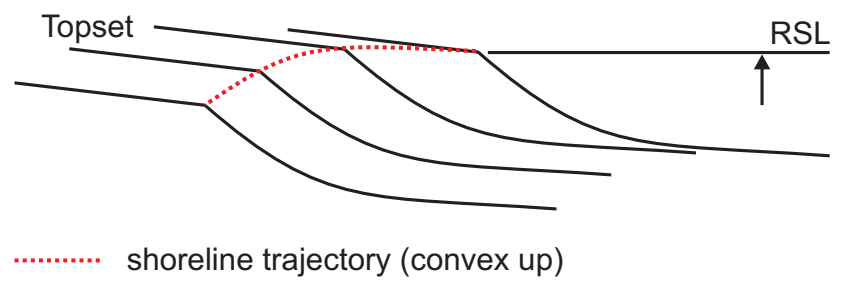

The rates of progradation increase with time, the rates of aggradation decrease with time.

Fig. 4. Stratal stacking patterns of 'lowstand' and 'highstand' normal regressions (modified from Catuneanu 2006). In both cases progradation is driven by sediment supply (overfilled accommodation at the shoreline). Lowstand normal regressions record a change in depositional trends from dominantly progradational to dominantly aggradational (concave up shoreline trajectory). In contrast, highstand normal regressions record a change from aggradation to progradation (convex up shoreline trajectory). Abbreviation: RSL - relative sea level.

of available accommodation results in progradation, whereas underfilled accommodation results in retrogradation. During stages of negative accommodation, processes of subaerial exposure and erosion are typically accompanied by progradation in the basinward parts of the depositional profile.

\section{Stratal stacking patterns}

Stratal stacking patterns may be defined either in relation to or independently of shoreline trajectories. Criteria involved in the definition of stratal stacking patterns include geometries and facies relationships that arose from the interplay of available accommodation and sediment supply at syn-depositional time.

Shoreline-related stacking patterns are defined by combinations of depositional trends that can be tied to specific types of shoreline trajectory: forced regression (forestepping and downstepping at the shoreline, interpreted as the result of negative accommodation); normal regression (forestepping and upstepping at the shoreline, interpreted as the result of positive and overfilled accommodation); and transgression (backstepping at the shoreline, interpreted as the result of posi- tive and underfilled accommodation) (Fig.3). In the case of stratigraphic cycles that include a stage of forced regression as well as a stage of transgression, normal regressions can occur during both lowstands and highstands of relative sea level and, consequently, the products may be classified as 'lowstand' and 'highstand' deposits (Fig.4). Forced regressions, normal regressions and transgressions can be observed in modern depositional settings (Fig.5), as well as in outcrop (Fig. 6) and subsurface (Figs. 7, 8). In addition to regressive or transgressive shorelines, stable shorelines may also develop where accommodation and sediment supply are in balance. However, as accommodation and sediment supply are controlled independently by different mechanisms, stable shorelines are unlikely to be maintained for any significant periods of time. The importance of shoreline trajectories, whether or not within a sequence stratigraphic context, was reiterated by Helland-Hansen and Hampson (2009).

Shoreline-independent stacking patterns may develop in areas remote from coeval shorelines where sedimentation processes are unaffected by shoreline shifts. Such stratal stacking patterns may be defined based on changes in depositional style that can be correlated re- 

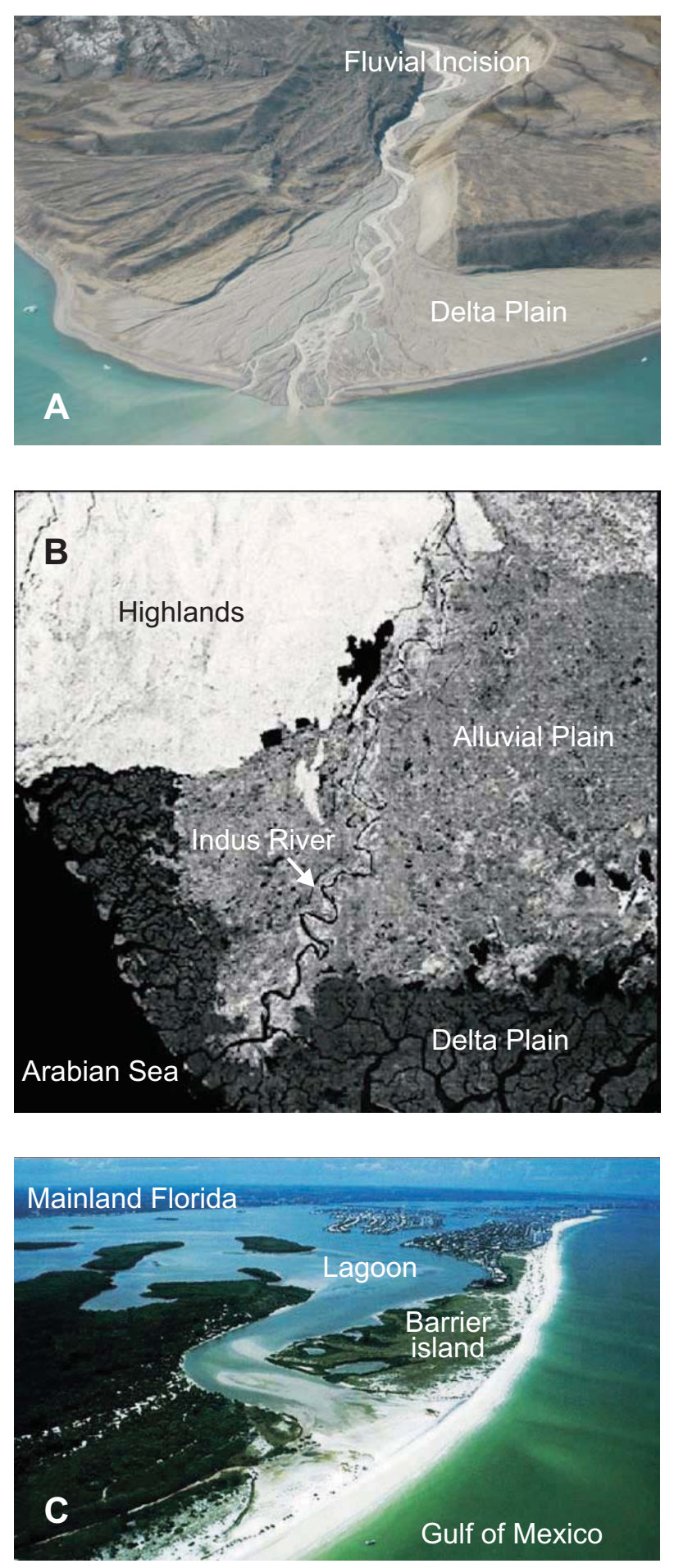

Fig. 5. Types of shoreline trajectory: present-day environment. A - forced regression (Svalbard; photograph courtesy of Jean-Loup Rubino); B - normal regression (Indus delta); $\mathrm{C}$ - transgression (Florida). See Figure 3 for stratal stacking patterns associated with these types of shoreline trajectory.
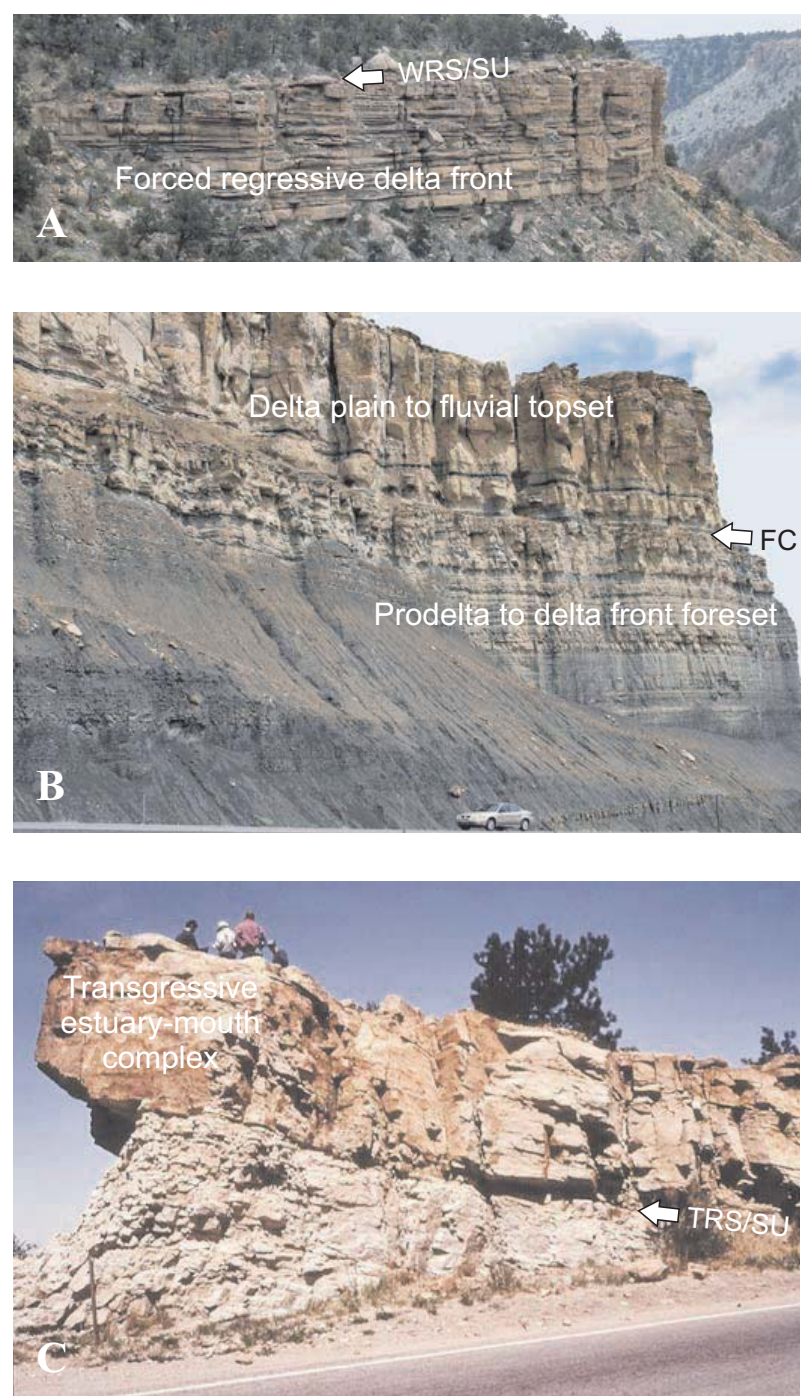

Fig. 6. Types of shoreline trajectory: outcrop examples. A - forced regression (Panther Tongue, Upper Cretaceous, Utah); B - normal regression (Ferron delta, Upper Cretaceous, Utah); C - transgression (Muddy Formation, Upper Cretaceous, Colorado). Abbreviations: WRS - wave-ravinement surface; FC - facies contact; SU - subaerial unconformity; TRS - tidal-ravinement surface. 

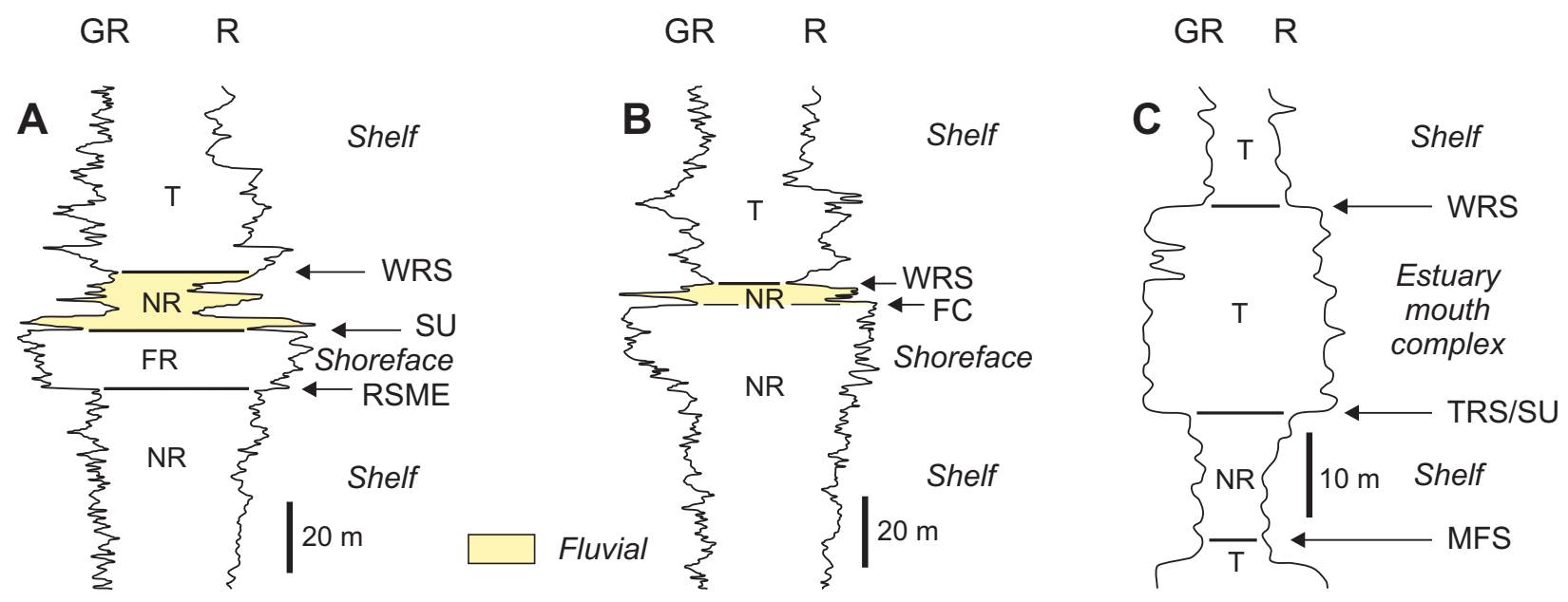

Fig. 7. Types of shoreline trajectory: well log examples. A - forced regression (sharp-based shoreface; Cardium Formation, Upper Cretaceous, Alberta); B - normal regression (gradationally based shoreface; Cardium Formation, Upper Cretaceous, Alberta); C - transgression (Colorado Group, Lower Cretaceous, Alberta). Abbreviations: GR - gamma ray log; R - resistivity log; FR - forced regressive; NR - normal regressive; T - transgressive; WRS - wave-ravinement surface; SU - subaerial unconformity; RSME - regressive surface of marine erosion; FC - facies contact; TRS - tidal-ravinement surface; MFS - maximum flooding surface.

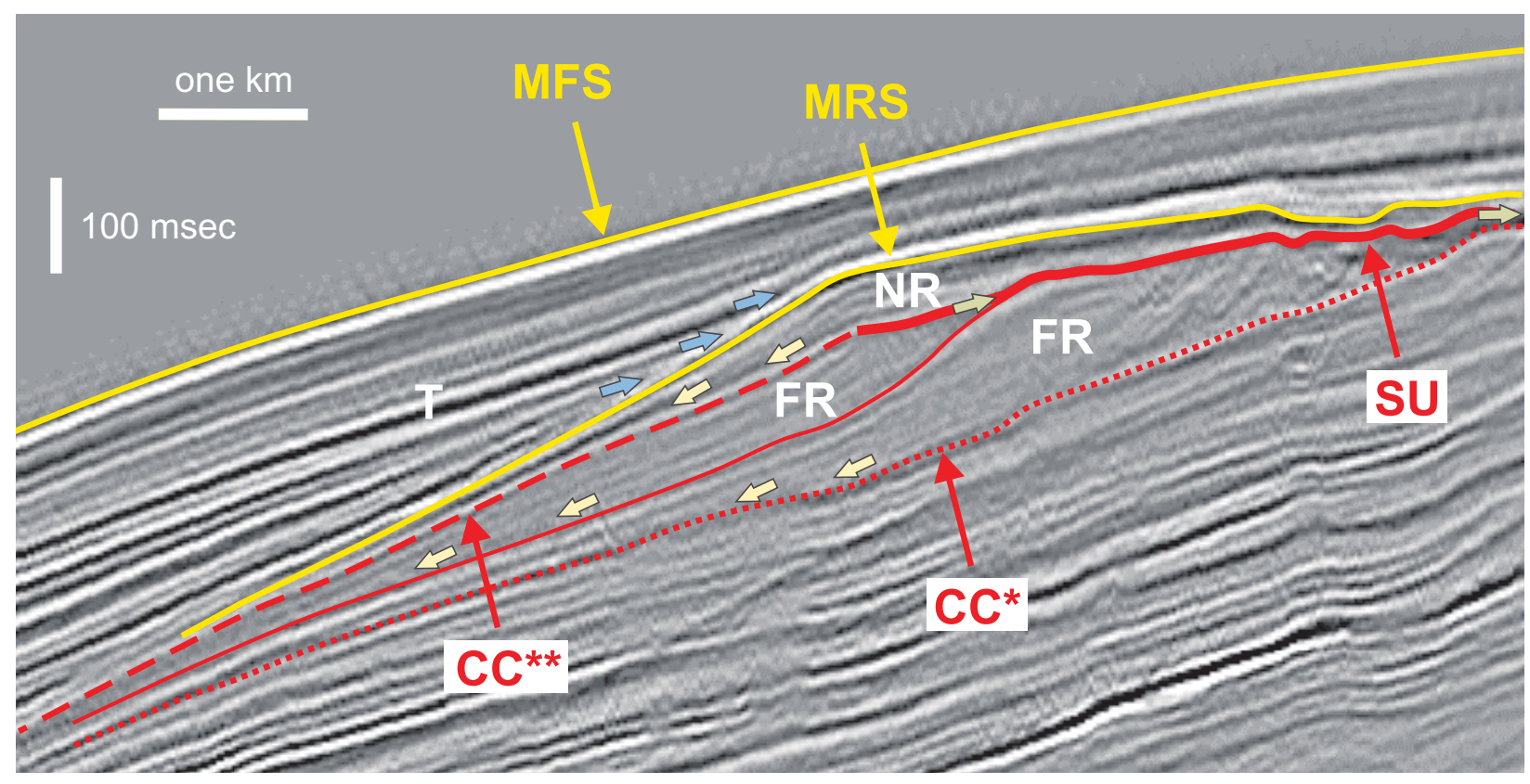

Fig. 8. Types of shoreline trajectory: seismic example (Plio-Pleistocene to Holocene, Gulf of Mexico; modified from Posamentier and Kolla 2003). Stratal terminations: green arrows - offlap; yellow arrows - downlap; blue arrows - onlap. Abbreviations: FR - forced regression; NR - normal regression; T - transgression; SU - subaerial unconformity; CC* - correlative conformity in the sense of Posamentier and Allen (1999) (= basal surface of forced regression); CC** - correlative conformity in the sense of Hunt and Tucker (1992); MRS - maximum regressive surface; MFS - maximum flooding surface. 

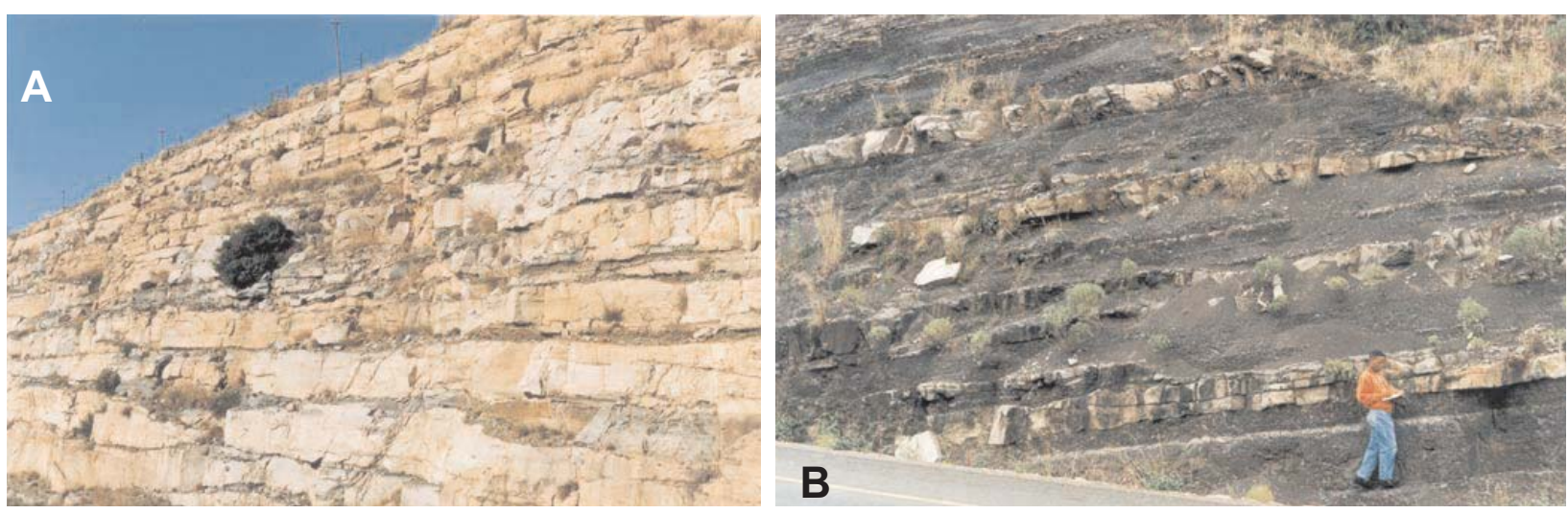

Fig. 9. Stratal stacking patterns in upstream-controlled fluvial systems. A - channel-dominated succession (low-accommodation setting: Katberg Formation, Early Triassic, Karoo Basin); B - overbank-dominated succession (high-accommodation setting: Burgersdorp Formation, Early-Middle Triassic, Karoo Basin).

gionally. Distinct depositional styles are characterized by specific types or combinations of depositional elements. In upstream-controlled fluvial settings, styles may be defined by the degree of amalgamation of channel deposits, which may reflect syn-depositional conditions of available fluvial accommodation (i.e., low- versus high-accommodation settings; e.g., Shanley and McCabe 1994; Boyd et al. 2000; Figs. 9, 10). In deep-water settings, depositional styles may be defined by the degree of channel confinement, which may reflect changes in accommodation on the shelf and/or variations in sediment supply in the staging area (e.g., Posamentier and Kolla 2003; Catuneanu et al. 2009; Figs. 11, 12). Some of these deep-water stacking patterns may be genetically related to shoreline trajectories, but there are also cases where offshore sub-basin tectonism may generate stacking patterns in a manner that is independent of changes in accommodation at the shoreline (e.g., Fiduk et al. 1999). The pattern of submarine fan sedimentation is also strongly dependent on the width of the continental shelf, the configuration of the continental margin, and their influence on sediment supply to the deep-water setting (e.g., Steel and Olsen 2002; Porebski and Steel 2006).

Fig. 10. Stratal stacking patterns of a fully fluvial succession in an overfilled foreland basin (Miocene, Assam Basin, India; from Catuneanu et al. 2009; well logs courtesy of the Oil and Natural Gas Corporation, India). The fluvial succession consists of depositional sequences bounded by subaerial unconformities, which may be subdivided into low- and high-accommodation systems tracts based on changes in depositional style that can be correlated regionally.

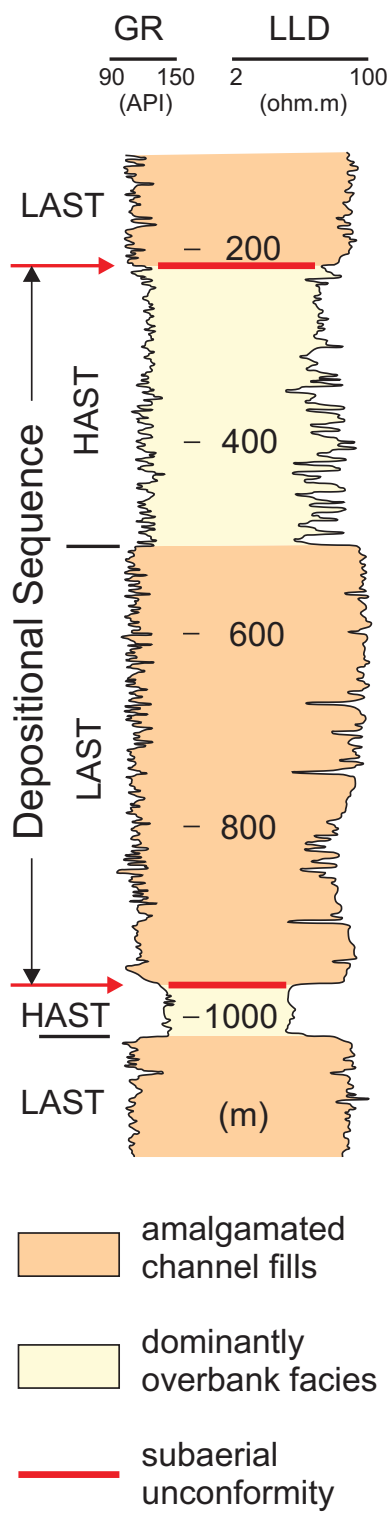



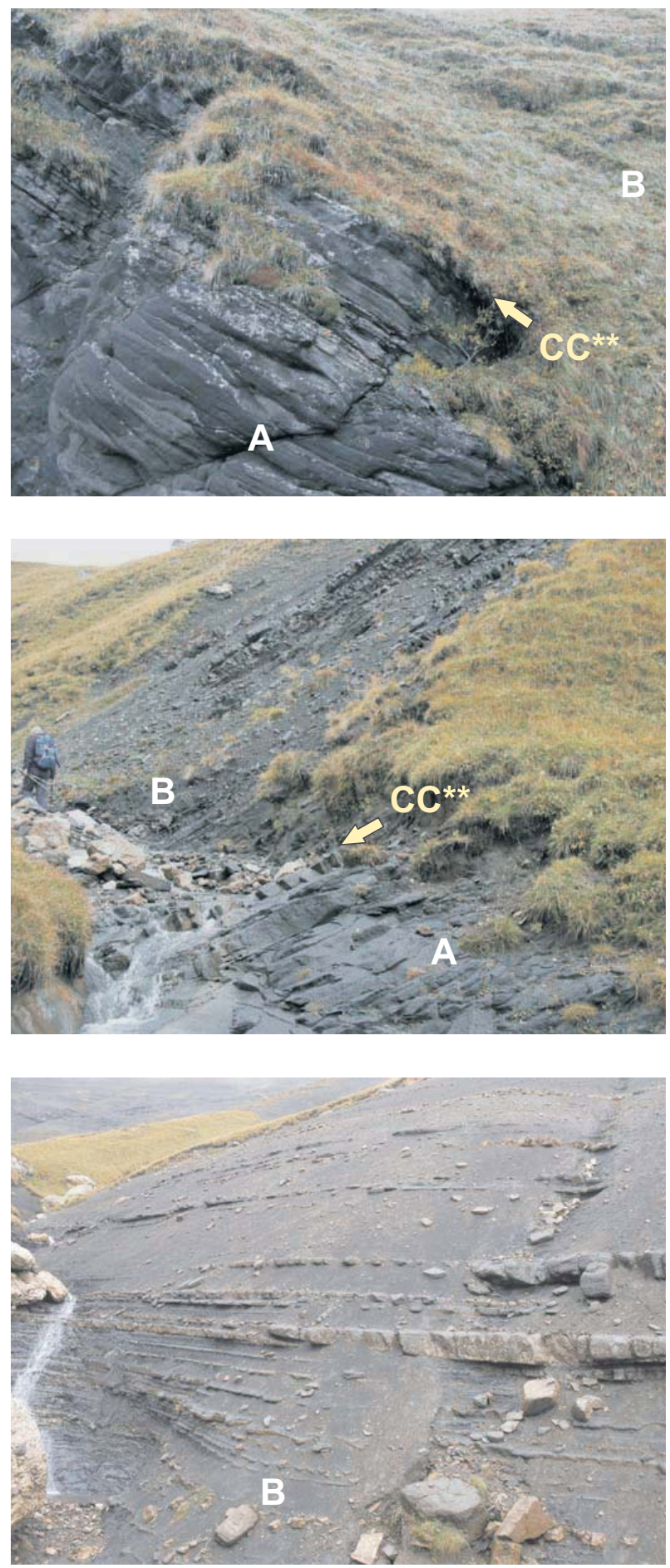

Fig. 11. Stratal stacking patterns in a deep-water setting (Triassic, The Dolomites, Italian Alps). A - splay-dominated succession of weakly confined and amalgamated channel deposits; B - overbank deposits of a leveed channel-dominated succession; $\mathrm{CC}^{* *}$ - correlative conformity sensu Hunt and Tucker (1992), marking the change from siliciclastic sediment (relative sea-level fall: carbonate factory switched off) to carbonate sediment (relative sea-level rise: carbonate factory switched on).
On carbonate platforms and ramps, sediment supply is to a large part controlled by the ecology of the carbonate-producing organisms, the contribution of nodirectly biogenic particles such as lime mud and ooids, and by currents and waves that distribute the sediment. The stacking patterns are defined by deepening-up, aggrading, and shallowing-up facies trends that may correlate with the shoreline shifts or develop independently (e.g., give-up, keep-up, catch-up situations of Kendall and Schlager 1981).

Whether or not their origin can be linked to shoreline trajectories, all types of stratal stacking patterns reflect the interplay of the same two fundamental variables, namely accommodation and sediment supply. Deposits defined by specific stratal stacking patterns form the basic constituents of any sequence stratigraphic unit, from sequence to systems tract and parasequence. Sequences, systems tracts, and parasequences may include both shoreline-related and shoreline-independent deposits and associated stacking patterns.

\section{Allogenic versus autogenic controls}

The sequence stratigraphic framework records the response to both allogenic and autogenic controls on sedimentation. Allogenic processes are external to the sedimentary unit, and typically record the effects of eustatic fluctuations, tectonism, and climate change. These processes represent the main control on accommodation.

Within individual depositional environments, autogenic processes of self organization towards the most energy-efficient state of equilibrium may generate stratigraphic signatures similar to those produced by allogenic mechanisms. Such processes may include channel avulsion, delta lobe switching without changes in the rates of sediment supply or accommodation, the generation of stepped surfaces during transgression, and the generation of multiple incisions during constant rates of negative accommodation (Muto and Steel 2001a, b, 2004).

Autogenic mechanisms may modulate the internal architecture of facies successions and depositional elements within the larger scale allogenic-controlled frameworks. The relevance of allogenic controls to the sequence stratigraphic architecture increases with the vertical and/or lateral scale of observation, whereas the importance of autogenic processes becomes more evident at smaller scales of observation. Sequences and systems tracts are commonly attributed to allogenic controls, whereas parasequences may be generated by either allogenic or autogenic mechanisms. 


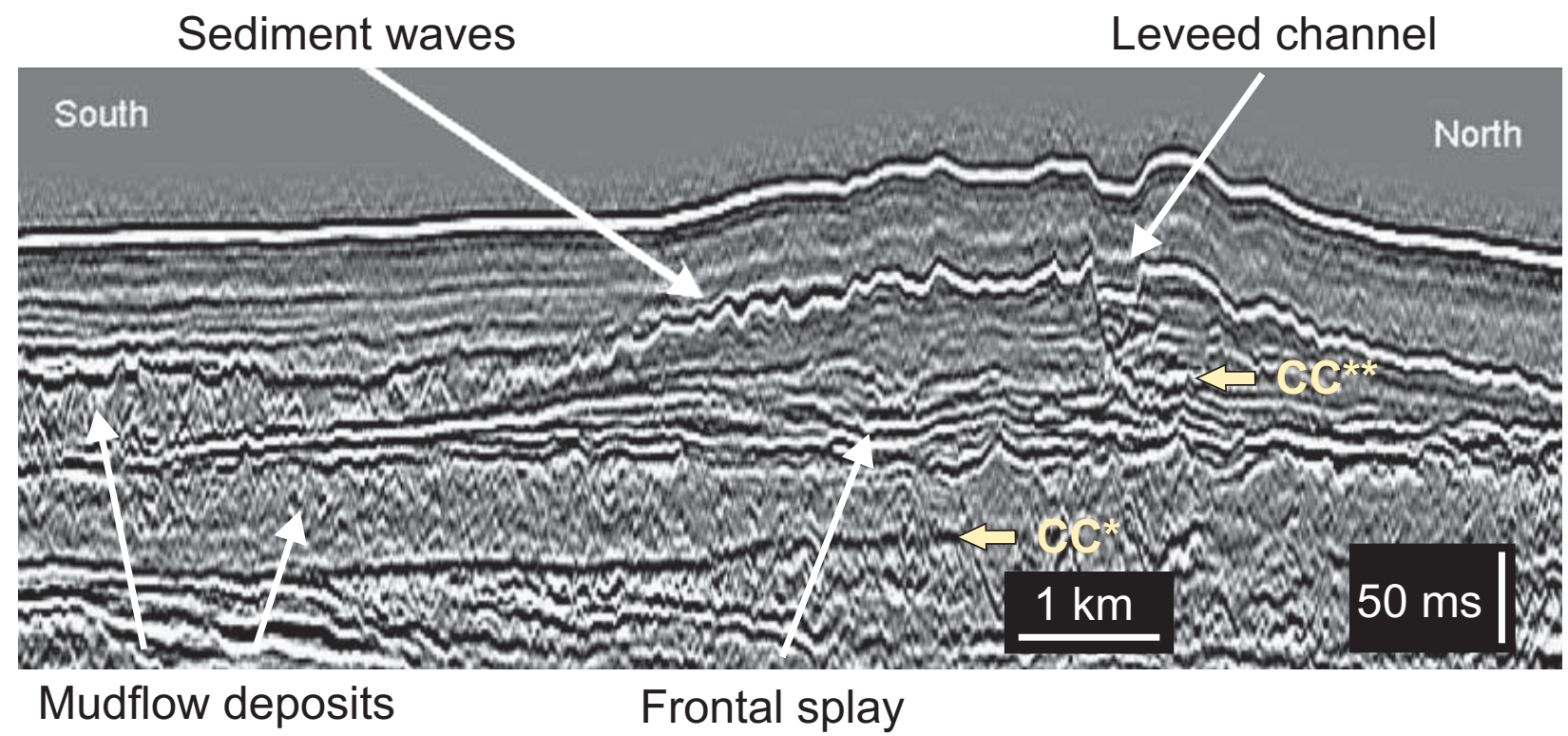

Fig. 12. Stratal stacking patterns in a deep-water setting (Plio-Pleistocene to Holocene, Gulf of Mexico; from Posamentier and Kolla 2003). CC* - correlative conformity sensu Posamentier and Allen (1999); CC** - correlative conformity sensu Hunt and Tucker (1992).

\section{Sequence stratigraphic units: Sequences}

\section{Definition}

A 'sequence' was originally defined as an unconformity-bounded stratigraphic unit (Sloss et al., 1949; Sloss 1963). The concept of sequence was subsequently revised to include "a relatively conformable succession of genetically related strata bounded by unconformities or their correlative conformities" (Mitchum 1977).

The continued development of the sequence stratigraphic paradigm in the 1980s and 1990s resulted in a diversification of approaches and the definition of several types of sequence (Figs. 1, 2): depositional sequences, bounded by subaerial unconformities and their marine correlative conformities (e.g., Vail 1987; Posamentier et al. 1988; Van Wagoner et al. 1988, 1990; Vail et al. 1991; Hunt and Tucker 1992); genetic stratigraphic sequences, bounded by maximum flooding surfaces (Galloway 1989); and transgressiveregressive (T-R) sequences, also referred to as T-R cycles, bounded by maximum regressive surfaces (Johnson and Murphy 1984; Johnson et al. 1985). The T-R sequence was subsequently redefined by Embry and Johannessen (1992) as a unit bounded by composite surfaces that include the subaerial unconformity and the marine portion of the maximum regressive surface.
The existence of several types of sequence requires a definition that is broad enough to accommodate all choices of approach. Every type of sequence may include unconformities within the sequence (Fig.2): depositional sequences and transgressive-regressive (T-R) sequences can include marine surfaces of nondeposition or erosion that can form during times of maximum shoreline transgression (i. e., unconformable maximum flooding surfaces); genetic stratigraphic sequences can contain surfaces that record stages of subaerial hiatus and erosion (i.e., subaerial unconformities). The potential presence of unconformities within a sequence indicates that the succession of strata comprising a sequence cannot always be described as 'relatively conformable' or 'genetically related'. For this reason, the concept of sequence was redefined as "a succession of strata deposited during a full cycle of change in accommodation or sediment supply" (Catuneanu et al. 2009). This definition is generic, model-independent, and embraces all types of sequence that may develop at any spatial or temporal scale.

The specification that a sequence corresponds to a full stratigraphic cycle is required to separate a sequence from component systems tracts. All existing sequence stratigraphic schemes (Figs. 1,2) incorporate a full cycle of change in accommodation or sediment supply in the definition of a sequence, because the beginning and the end of one cycle is marked by the same 
type of 'event': the onset of relative sea-level fall; the end of relative sea-level fall; the end of regression; or the end of transgression (Fig. 2). In contrast, the boundaries of any systems tract correspond to different 'events' of the relative sea-level cycle (Fig. 2).

\section{Types of sequence}

\section{Depositional sequences}

A depositional sequence forms during a full cycle of change in accommodation, which involves both an increase (positive) and decrease (negative) in the space available for sediments to fill. The formation of depositional sequence boundaries requires periods of negative accommodation. The dependency of depositional sequences on negative accommodation (whether in continental or marine settings), in addition to the nature of bounding surfaces, separates depositional sequences from other types of sequence stratigraphic unit, the formation of which may not require negative accommodation (i.e., parasequences, genetic stratigraphic sequences, T-R sequences in the sense of Johnson and Murphy (1984), and systems tracts that form during positive accommodation).

\section{Genetic stratigraphic sequences}

The formation of genetic stratigraphic sequences depends on the development of maximum flooding surfaces, which form during times of positive accommodation. A genetic stratigraphic sequence may form during a full cycle of change in accommodation, as in the case of a depositional sequence, but it may also form during periods of positive accommodation in response to fluctuations in the rates of accommodation creation and/or sediment supply. Consequently, a genetic stratigraphic sequence may or may not include an internal subaerial unconformity, depending on whether or not the corresponding cycle includes a stage of negative accommodation. Maximum flooding surfaces may include unconformable portions expressed as "hiatal surfaces preserved as marine unconformities" (Galloway 1989). Such unconformities may develop on the shelf and slope because of sediment starvation, shelf-edge instability and erosion during transgression. Where present, unconformable maximum flooding surfaces are included within but do not constitute the bounding surfaces defining depositional sequences and T-R sequences.

\section{Transgressive-regressive (T-R) sequences}

The original T-R sequence of Johnson and Murphy (1984) depends on the development of maximum re- gressive surfaces, which form during times of positive accommodation. As in the case of genetic stratigraphic sequences, this type of sequence may form during a full cycle of change in accommodation, but it may also form during periods of positive accommodation as a result of fluctuations in the rates of accommodation and/or sediment supply. By contrast, the T-R sequence of Embry and Johannessen (1992) is dependent on negative accommodation, as it requires a subaerial unconformity at the sequence boundary. As the maximum regressive surface is younger than the subaerial unconformity, the marine portion of the maximum regressive surface may or may not meet with the basinward termination of the subaerial unconformity (Embry and Johannessen 1992). The temporal and spatial offset between the two portions of the sequence boundary is increasingly evident at larger scales of observation (Catuneanu et al. 2009).

\section{Sequence stratigraphic units: Systems tracts}

\section{Definition}

A systems tract is "a linkage of contemporaneous depositional systems, forming the subdivision of a sequence" (Brown and Fisher 1977). The definition of a systems tract is independent of spatial and temporal scales. The internal architecture of a systems tract may vary greatly with the scale of observation, from a succession of facies (e.g., in the case of high-frequency sequences driven by orbital forcing) to a parasequence set or a set of higher frequency sequences.

A systems tract consists of a relatively conformable succession of genetically related strata bounded by conformable or unconformable sequence stratigraphic surfaces. As discussed by Catuneanu et al. (2009), the original definition of a sequence provided by Mitchum (1977) is more applicable to the concept of systems tracts than it is to the concept of sequence. This is because sequences may include internal unconformities, whereas such unconformities, where present, are always placed at the boundary between systems tracts. This discussion considers sequences, systems tracts and bounding surfaces that develop at the same hierarchical level: discontinuities of a higher frequency (i.e., lower hierarchical rank) can occur within a sequence or systems tract without violating the above definitions.

Systems tracts are interpreted on the basis of stratal stacking patterns, position within the sequence, and 
types of bounding surface (Van Wagoner et al. 1987, 1988, 1990; Posamentier et al. 1988; Van Wagoner 1995; Posamentier and Allen 1999). Systems tracts may be either shoreline-related, where their origin can be linked to particular types of shoreline trajectory, or shoreline-independent, where a genetic link to coeval shorelines cannot be determined.

\section{Shoreline-related systems tracts}

Shoreline-related systems tracts consist of correlatable depositional systems that are genetically related to specific types of shoreline trajectory (i.e., forced regression, normal regression, transgression). These systems tracts may be observed at different scales, and are defined by distinct stratal stacking patterns (Figs. 3, 5-8).

The systems tract nomenclature applied to forced regressive deposits includes 'early lowstand', 'late highstand', 'forced-regressive wedge', and 'falling-stage'. The systems tract nomenclature applied to lowstand normal regressive deposits includes 'late lowstand' and 'lowstand', whereas highstand normal regressive deposits are designated as 'highstand' or 'early highstand' systems tracts. In all sequence stratigraphic schemes, the transgressive deposits comprise the transgressive systems tract (Fig. 2).

Shoreline-related systems tracts are commonly interpreted to form during specific phases of the relative sea-level cycle (Posamentier et al. 1988; Hunt and Tucker 1992; Posamentier and Allen 1999; Catuneanu 2006; Catuneanu et al. 2009; Fig.2). Five of these systems tracts are presented below.

\section{Falling-Stage Systems Tract (FSST)}

The FSST includes all the regressive deposits that accumulate after the onset of a relative sea-level fall and before the start of the next relative sea-level rise. The FSST is the product of a forced regression. The FSST lies directly on the sequence boundary sensu Posamentier and Allen (1999) and is capped by the overlying Lowstand Systems Tract (LST) sediments. However, Hunt and Tucker (1992) placed the sequence boundary above the FSST, since in their view the boundary here marked the termination of one cycle of deposition and the start of another. A variety of parasequence stacking patterns can be produced, with 'attached' or 'detached' architecture, depending on the gradient of the depositional profile, the rate of sediment supply, and the rate of relative sea-level fall (Posamentier and Morris 2000). The characteristics of the FSST were set out by Hunt and Tucker (1992), Nummedal (1992) and Ains- worth (1994). The terminology applied to this systems tract varied from 'forced regressive wedge' (Hunt and Tucker 1992) to 'falling sea-level' (Nummedal 1992) and 'falling-stage' (Ainsworth 1994). The simpler 'falling-stage' has been generally adopted by more recent work (e.g., Plint and Nummedal 2000; Catuneanu 2006). This systems tract has also been termed the Early Lowstand Systems Tract (Posamentier et al. 1988; Posamentier and Allen 1999).

The fall in relative sea level is evidenced by the erosion of the subaerially exposed sediment surface updip of the coastline at the end of forced regression, and the formation of a diachronous subaerial unconformity that caps the Highstand Systems Tract (HST). The subaerial unconformity may be onlapped by fluvial deposits that belong to the lowstand or the transgressive systems tracts. The subaerial unconformity may also be reworked by a time-transgressive marine ravinement surface overlain by a sediment lag.

\section{Lowstand Systems Tract (LST)}

The LST includes deposits that accumulate after the onset of relative sea-level rise, during normal regression, on top of the FSST and the corresponding updip subaerial unconformity. Stacking patterns exhibit forestepping, aggrading clinoforms that (in siliciclastic systems) thicken downdip, and a topset of fluvial, coastal plain and/or delta plain deposits. LST sediments often fill or partially infill incised valleys that were cut into the HST, and other earlier deposits, during forced regression. This systems tract has also been termed the Late Lowstand Systems Tract (Posamentier et al. 1988; Posamentier and Allen 1999) or the Lowstand Prograding Wedge Systems Tract (Hunt and Tucker 1992).

In earlier papers the 'Shelf-margin Systems Tract' was recognized as the lowermost systems tract associated with a 'type 2' sequence boundary (Posamentier et al. 1988). With the abandonment of the distinction between types 1 and 2 sequence boundaries, this term is now redundant (Posamentier and Allen 1999; Catuneanu 2006); these deposits are now considered to be part of the LST.

\section{Transgressive Systems Tract (TST)}

The TST comprises the deposits that accumulated from the onset of transgression until the time of maximum transgression of the coast, just prior to the renewed regression of the HST. The TST lies directly on the maximum regressive surface formed at the end of regression (also termed a 'transgressive surface') and 
is overlain by the 'maximum flooding surface' (MFS) formed when marine sediments reach their most landward position. Stacking patterns exhibit backstepping, onlapping, retrogradational clinoforms that (in siliciclastic systems) thicken landward. In cases where there is a high sediment supply the parasequences may be aggradational.

\section{Highstand Systems Tract (HST)}

The HST includes the progradational deposits that form when sediment accumulation rates exceed the rate of increase in accommodation during the late stages of relative sea-level rise (Fig.2). The HST lies directly on the MFS formed when marine sediments reached their most landward position. This systems tract is capped by the subaerial unconformity and its correlative conformity sensu Posamentier and Allen (1999). Stacking patterns exhibit prograding and aggrading clinoforms that commonly thin downdip, capped by a topset of fluvial, coastal plain and/or delta plain deposits.

\section{Regressive System Tract (RST)}

The RST lies above a TST and is overlain by the initial transgressive surface of the overlying TST. The complete sequence is known as a Transgressive-Regressive (T-R) Sequence (Johnson and Murphy 1984; Embry and Johannessen 1992). The sediments of this systems tract include the HST, FSST and LST systems tracts defined above.

There are cases where the data available are insufficient to differentiate between HST, FSST an HST systems tracts. In such cases the usage of the Regressive Systems Tract is justified. However, where permitted by data, the differentiation between the three types of regressive deposits (highstand, falling-stage, lowstand) is recommended because they refer to different stratal stacking patterns; are characterized by different sediment dispersal patterns within the basin; and consequently are associated with different petroleum plays. The last aspect relates to one of the most significant applications of sequence stratigraphy, which is to increase the resolution of stratigraphic frameworks that can optimize petroleum exploration and production development.

\section{Shoreline-independent systems tracts}

Shoreline-independent systems tracts are stratigraphic units that form the subdivisions of sequences in areas where sedimentation processes are unrelated to shore- line shifts. These systems tracts are defined by specific stratal stacking patterns that can be recognized and correlated regionally, without reference to shoreline trajectories (Figs. 9-12). In upstream-controlled fluvial settings, fluvial accommodation may change independently of changes in accommodation at the nearest shoreline and create sequences and component low- and high-accommodation systems tracts (e.g., Shanley and McCabe 1994; Boyd et al. 2000). Shoreline-independent systems tracts may also be mapped in deep-water settings controlled by sub-basin tectonism (e.g., Fiduk et al. 1999), but no nomenclature has been proposed for these situations. The timing of shorelineindependent sequences and systems tracts is commonly offset relative to that of shoreline-controlled sequence stratigraphic units and bounding surfaces (e.g., Blum and Tornqvist 2000).

\section{Sequence stratigraphic units: Parasequences}

\section{Definition}

A parasequence in its original definition (Van Wagoner et al. 1988, 1990) is an upward-shallowing succession of facies bounded by marine flooding surfaces. A marine flooding surface is a lithological discontinuity across which there is an abrupt shift of facies that commonly indicates an abrupt increase in water depth.

The concept was originally defined, and is commonly applied, within the context of siliciclastic coastal to shallow-water settings, where parasequences correspond to individual prograding sediment bodies (Fig. 13). In carbonate settings, a parasequence corresponds to a succession of facies commonly containing a lag deposit or thin deepening interval followed by a thicker shallowing-upward part, as for example in peritidal cycles (Fig. 14).

In contrast to sequences and systems tracts, which may potentially be mapped across an entire sedimentary basin from fluvial into the deep-water setting, parasequences are geographically restricted to the coastal to shallow-water areas where marine flooding surfaces may form (Posamentier and Allen 1999). In the case of carbonate settings, peritidal cycles can in some cases be correlated into slope and basinal facies (e.g., Chen and Tucker 2003). For this reason, it has been proposed that 'parasequence' be expanded to include all regional meter-scale cycles, whether or not they are bounded by flooding surfaces (Spence and 
Fig. 13. Upstepping parasequences (Late Permian Waterford Formation, Ecca Group, Karoo Basin). The parasequence boundaries are marked by flooding surfaces. Each parasequence consists of normal regressive and transgressive deposits. Abbreviations: FS - flooding surface; c-u coarsening-upward trend.
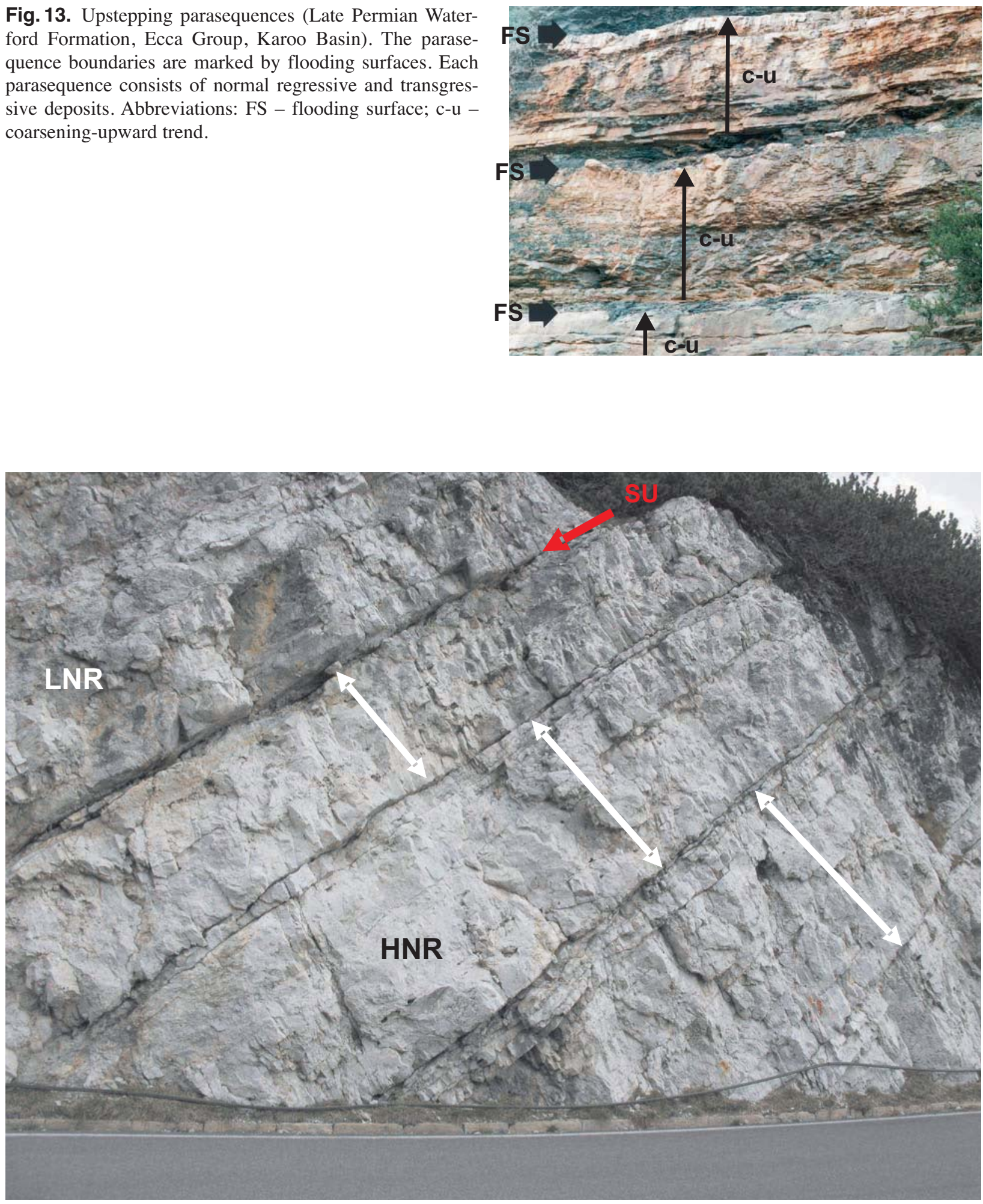

Fig. 14. Peritidal cycles in a platform top setting (Triassic, The Dolomites, Italy). Note the trend of upwards decrease in the thickness of peritidal cycles, which is typical of highstand topsets. This trend is caused by the gradual decrease in the rates of creation of accommodation during highstand normal regression (see Fig. 4 for comparison). The highstand deposits are overlain unconformably by the lowstand topset, which displays a more pronounced continental influence (e.g., red mudstones, calcareous paleosols with caliches, calcareous sandstones, vadose pisoliths, teepee structures; P. Gianolla, pers. comm.). Abbreviations: SU - subaerial unconformity; HNR - highstand normal regression; LNR - lowstand normal regression. 
Tucker 2007; Tucker and Garland 2010). However, following the principle that a sequence stratigraphic unit is defined by specific bounding surfaces, most practitioners favor restricting the concept of parasequence to a unit bounded by marine flooding surfaces, in agreement with the original definition of Van Wagoner et al. (1988, 1990).

\section{Scale and stacking patterns}

Parasequences are commonly nested within larger scale (higher rank) sequences and systems tracts. However, scale is not sufficient to differentiate parasequences from sequences. For example, high-frequency sequences controlled by orbital forcing may develop at scales comparable to, or even smaller than, those of many parasequences (e.g., Strasser et al. 1999; Fielding et al. 2008; Tucker et al. 2009). As such, even cycles as thin as a meter can sometimes be referred to as sequences and be described and interpreted in terms of sequence stratigraphic surfaces and systems tracts (e.g., Posamentier et al. 1992a; Strasser et al. 1999; Tucker et al. 2009). We recommend the use of the sequence stratigraphic methodology to the analysis of any small, meter-scale cycles, as long as they display depositional trends that afford the recognition of systems tracts and diagnostic bounding surfaces.

Parasequences consist of normal regressive, transgressive and forced regressive types of deposit, and display various stacking patterns. Parasequences may be stacked in an upstepping succession, in which case they consist of normal regressive and transgressive deposits that accumulate during a period of positive accommodation in response to variations in the rates of accommodation and/or sediment supply (Fig.13). Upstepping parasequences may either be forestepping (Fig. 15) or backstepping (Fig. 16). Parasequences may also be stacked in a downstepping succession, in which case they consist primarily of forced regressive deposits that accumulate during a period of overall negative accommodation (Fig. 17). However, negative accommodation does not occur during the time of formation of the parasequence boundary. The pattern of stacking of parasequences defines longer term normal regressions (Fig. 15), forced regressions (Fig. 17) or transgressions (Fig. 16), which correspond to shoreline-related systems tracts of higher hierarchical rank (Fig. 3).

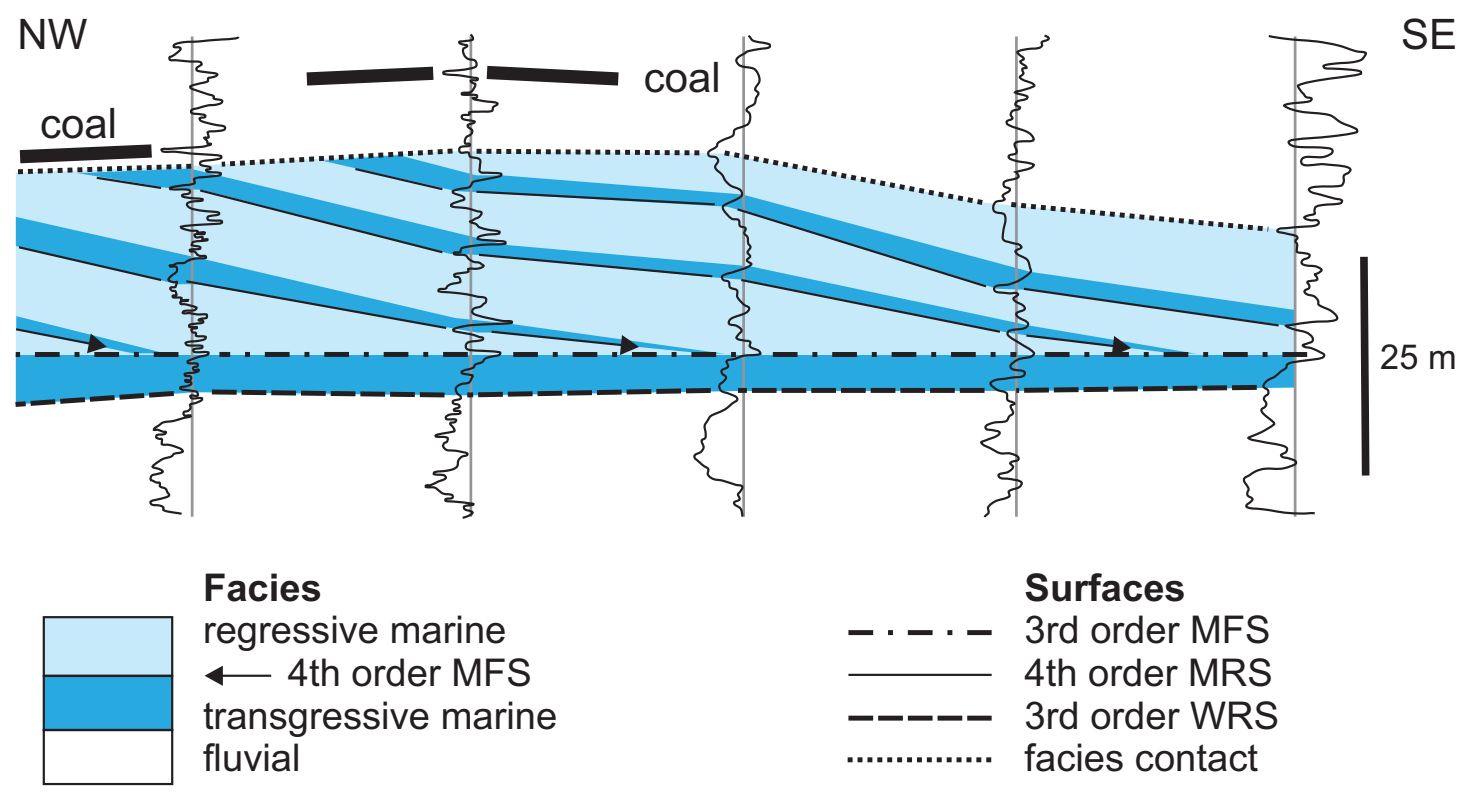

Fig. 15. Dip-oriented cross-section through the marine facies of Bearpaw Formation, based on gamma-ray well logs (Upper Cretaceous, Alberta; modified from Catuneanu 2006). The section is approximately $30 \mathrm{~km}$ long. The internal architecture of the marine unit shows upstepping and prograding lobes (parasequences), which downlap the main maximum flooding surface of the Bearpaw seaway. Each prograding lobe consists of normal regressive and transgressive deposits. The pattern of stacking of parasequences defines a long-term normal regression. Abbreviations: MFS - maximum flooding surface; MRS - maximum regressive surface; WRS - wave ravinement surface. 


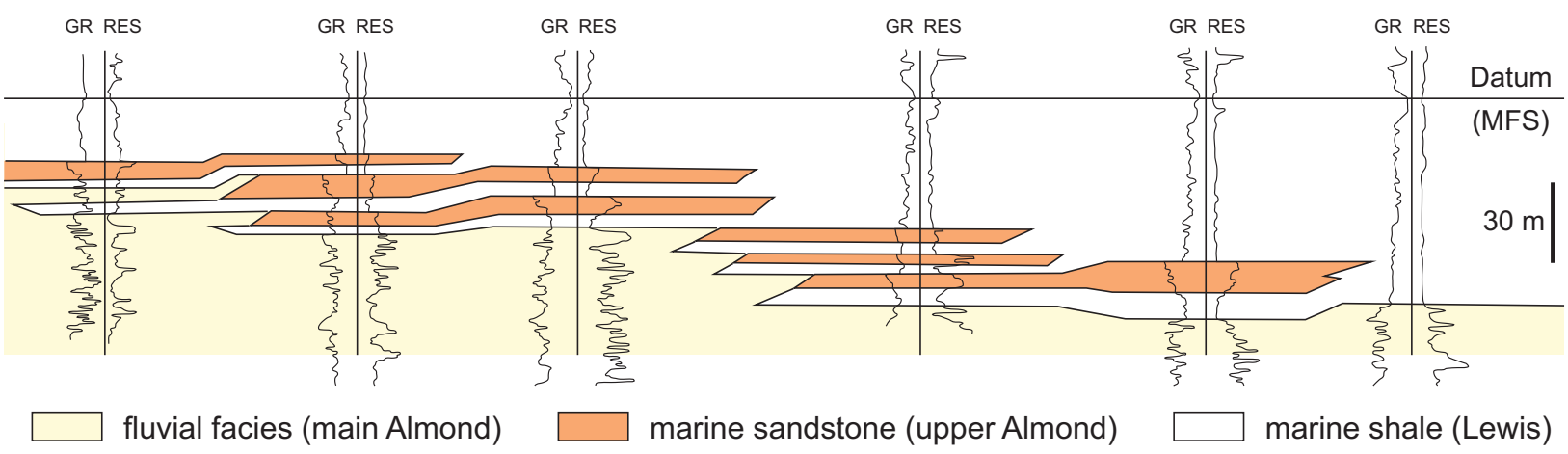

Fig. 16. Regional well-log cross-section of the Almond Formation in the Washakie Basin, Wyoming. The backstepping stacking pattern of parasequences records the overall transgression of the Western Interior Seaway during the Campanian. Each individual parasequence consists of normal regressive and transgressive deposits. The cross-section is approximately $65 \mathrm{~km}$ long. Well logs shown: gamma ray (GR) and resistivity (RES). Modified from Weimer (1966), Martinsen and Christensen (1992) and C. Bartberger (pers. comm.).

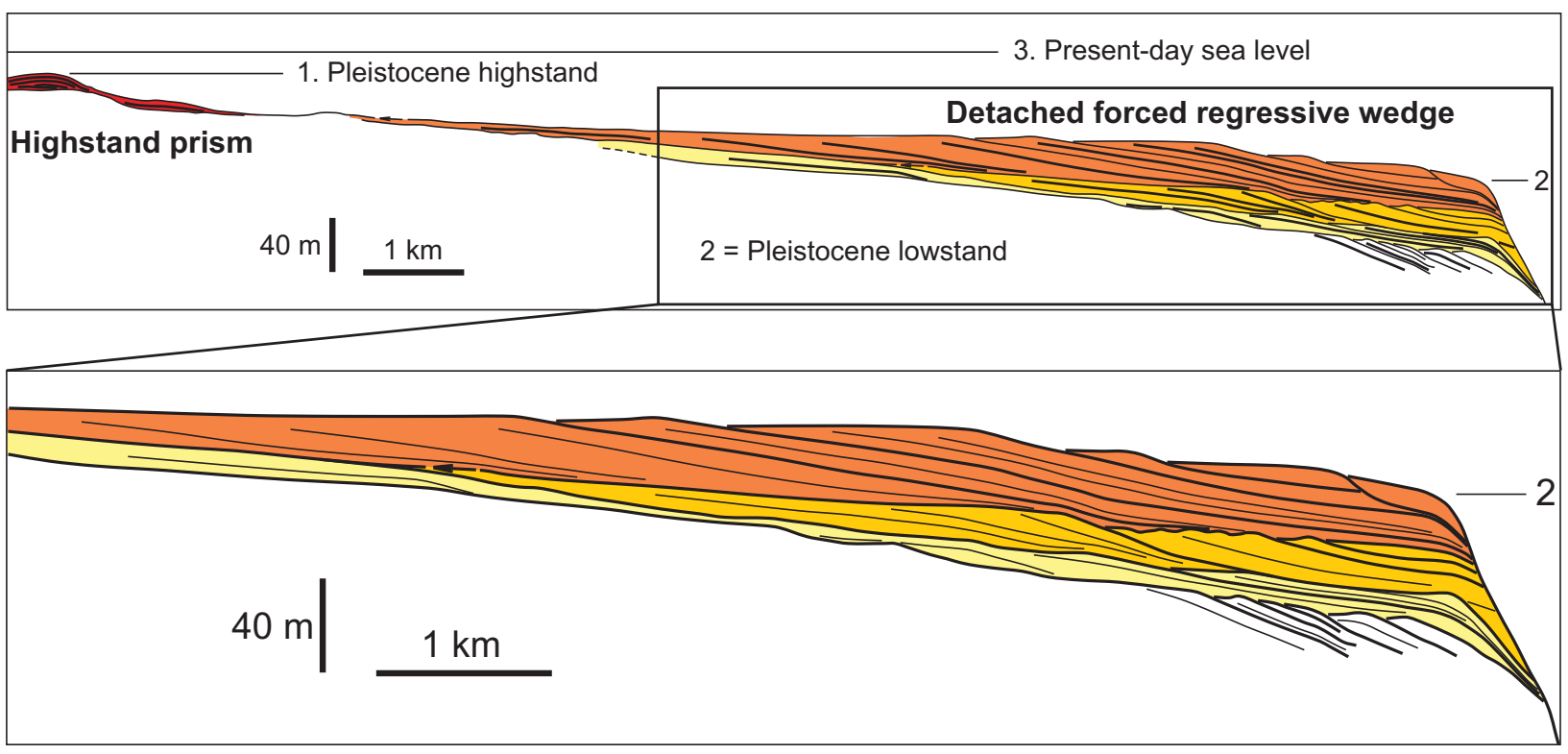

Fig. 17. Cross-section through the Pleistocene deposits of the Rhône shelf (offshore southeastern France), based on a regional seismic line. The three unconformity-bounded depositional sequences correspond to high-frequency glacial-interglacial cycles. Each sequence consists primarily of forced regressive deposits, which show a lateral stacking of downstepping parasequences. Modified from Posamentier et al. (1992b).

\section{Sequence stratigraphic surfaces}

\section{Definition}

Sequence stratigraphic surfaces mark changes in stratal stacking pattern. They are surfaces that can serve, at least in part, as systems tract boundaries.

Sequence stratigraphic surfaces may correspond to 'conceptual' horizons (i.e., without a lithologic con- trast) or physical surfaces, depending on their outcrop expression (e.g., Carter et al. 1998). Unconformable sequence stratigraphic surfaces typically have a physical expression. Any conformable sequence stratigraphic surface may be a 'conceptual' horizon or an observable surface with physical attributes, depending on local conditions of deposition or preservation.

A set of seven sequence stratigraphic surfaces, including two types of correlative conformities, is in 
widespread use. Criteria for mapping each type of sequence stratigraphic surface are summarized in Catuneanu (2006).

\section{Subaerial unconformity}

The subaerial unconformity (Sloss et al. 1949) is an unconformity that forms under subaerial conditions as a result of fluvial erosion or bypass, pedogenesis, wind degradation, or dissolution and karstification. Alternative terms include: 'lowstand unconformity' (Schlager 1992), 'regressive surface of fluvial erosion' (Plint and Nummedal 2000), and 'fluvial entrenchment/incision surface’ (Galloway 2004).

Subaerial unconformities may form during forced regression, within the downstream-controlled portion of fluvial systems (e.g., Posamentier et al. 1988); during transgression accompanied by coastal erosion (e. g., Leckie 1994); during periods of negative fluvial accommodation within the upstream-controlled portion of fluvial systems (e.g., Blum 1994); or during relative sea-level fall exposing carbonate platforms and reefs to karstification.

\section{Correlative conformities}

The correlative conformity in the sense of Posamentier et al. (1988) is a marine stratigraphic surface that marks the change in stratal stacking patterns from highstand normal regression to forced regression. It is the paleo-seafloor at the onset of forced regression. An alternative term is 'basal surface of forced regression' (Hunt and Tucker 1992).

The correlative conformity in the sense of Hunt and Tucker (1992) is a marine stratigraphic surface that marks the change in stratal stacking patterns from forced regression to lowstand normal regression. It therefore records the paleo-seafloor at the end of forced regression.

\section{Maximum flooding surface}

The maximum flooding surface (Frazier 1974; Posamentier et al. 1988; Van Wagoner et al. 1988; Galloway 1989) is a stratigraphic surface that marks a change in stratal stacking patterns from transgression to highstand normal regression. It is the paleo-seafloor at the end of transgression, and its correlative surface within the nonmarine setting. Alternative terms include: 'final transgressive surface' (Nummedal et al. 1993), 'surface of maximum transgression' (Helland-
Hansen and Gjelberg 1994), and 'maximum transgressive surface' (Helland-Hansen and Martinsen 1996). Sometimes the switch in depositional trend from retrogradation to progradation is marked by a zone of (commonly condensed) deep-water facies rather than a unique surface and this can lend itself to ambiguity in the placing of this surface in the rock succession (Carter et al. 1998). The maximum flooding surface is often expressed as a downlap surface in seismic stratigraphic terms, as it is typically downlapped by the overlying highstand clinoforms which record progradation.

\section{Maximum regressive surface}

The maximum regressive surface (Helland-Hansen and Martinsen 1996) is a stratigraphic surface that marks a change in stratal stacking patterns from lowstand normal regression to transgression. It is the paleo-seafloor at the end of lowstand normal regression, and its correlative surface within the nonmarine setting. Alternative terms include: 'transgressive surface' (Posamentier and Vail 1988), 'top of lowstand surface' (Vail et al. 1991), 'initial transgressive surface' (Nummedal et al. 1993), 'surface of maximum regression' (HellandHansen and Gjelberg 1994; Mellere and Steel 1995), 'conformable transgressive surface' (Embry 1995), and 'maximum progradation surface' (Emery and Myers 1996). The term 'maximum regressive surface' is recommended where emphasis is placed on the end of regression, and the term 'transgressive surface' is recommended where emphasis is placed on the onset of transgression.

\section{Transgressive ravinement surfaces}

The transgressive ravinement surfaces (Nummedal and Swift 1987) are erosional surfaces that form by means of wave scouring (i.e., wave-ravinement surfaces; Swift 1975) or tidal scouring (i.e., tidal-ravinement surfaces; Allen and Posamentier 1993) during transgression in coastal to shallow-water environments. Both types of transgressive ravinement surfaces are diachronous, younging towards the basin margin (Nummedal and Swift 1987). Their basinward termination merges into the maximum regressive surface; their landward termination merges into the maximum flooding surface. An alternative term for either type of transgressive ravinement surface is the 'transgressive surface of erosion' (Posamentier and Vail 1988). 


\section{Regressive surface of marine erosion}

The regressive surface of marine erosion (Plint 1988) is an erosional surface that forms typically by means of wave scouring during forced regression in wavedominated shallow-water settings due to the lowering of the wave base relative to the seafloor. However, this scour may also form under conditions of high-energy normal regression, where the shoreline trajectory is horizontal (i.e., progradation during a stillstand of relative sea level) or rising at a low angle (i.e., progradation during low rates of relative sea-level rise; Helland-Hansen and Martinsen 1996). The regressive surface of marine erosion is diachronous, younging basinward with the rate of shoreline regression. Alternative terms include: 'regressive ravinement surface' (Galloway 2001), and 'regressive wave ravinement' (Galloway 2004).

\section{Hierarchy in sequence stratigraphy}

The concept of hierarchy refers to the classification of sequences based on their relative scale and stratigraphic significance (Fig. 18).

Sequence-forming processes have natural periodicities. This led to the definition of hierarchy of sequences based on the duration of cycles (e.g., Vail et al. 1977, 1991; Van Wagoner et al. 1990; Mitchum and

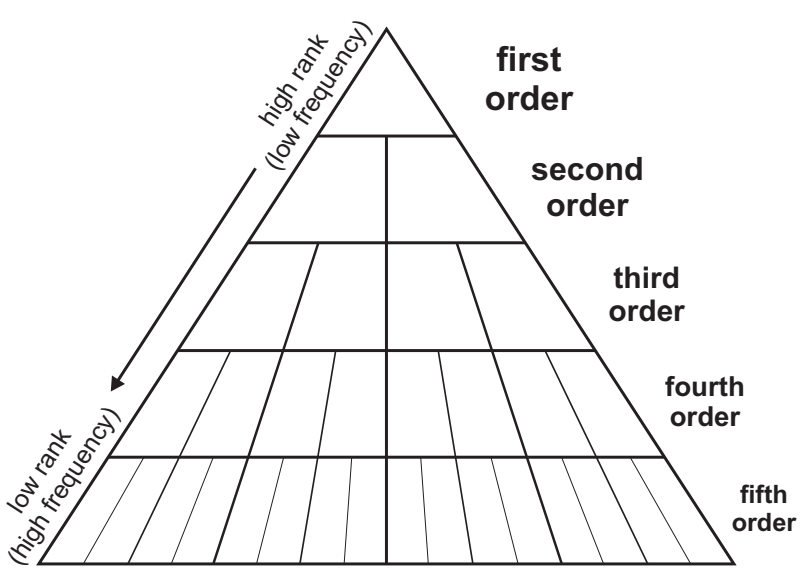

Fig. 18. Diagrammatic representation of the concept of hierarchy. The use of 'low' versus 'high' orders is inconsistent: some refer to first-order cycles as high order, making reference to the high position of those cycles within the hierarchy pyramid; others refer to first-order cycles as low order, making reference to the numbers attributed to each order. For this reason, we recommend the less ambiguous terms of 'high rank' versus 'low rank'.
Van Wagoner 1991). However, the rates and periodicity of specific processes changed over geologic time, and the time spans of different process-related cycles overlap (Miall 2010). These facts raise questions with respect to the utility of a hierarchical system that is based on the duration of stratigraphic cycles (e.g., Carter et al. 1991; Drummond and Wilkinson 1996; Schlager 2010).

The temporal and spatial scales of sequences do not define mutually exclusive ranges (Carter et al. 1991). The quantitative study of the duration and thickness of stratigraphic sequences made by Drummond and Wilkinson (1996) confirmed that the discrimination of stratigraphic hierarchies and their rank designation represent rather arbitrary subdivisions of an uninterrupted stratigraphic continuum. Schlager (2004) proposed that at least at time scales of $10^{3}-10^{6} \mathrm{yr}$, sequences and systems tracts are scale-invariant fractal features, even though different hierarchical orders may involve different levels of stratigraphic complexity. The scale-independent, fractal-like nature of stratigraphic cycles has also been demonstrated by means of laboratory experiments and modelling (e.g., Martin et al. 2009).

These conclusions question whether a universal and reproducible system of hierarchy exists at all in the stratigraphic rock record, and seem particularly true for tectonically generated sequences. However, Milankovitch-band cycles may give discrete modes in the frequency distribution of sequence durations, albeit with slight change over geologic time, if they are not overprinted by other sequence-forming mechanisms that may operate within similar temporal scales. If it can be demonstrated that the hierarchy in the stacking of sequences was induced by orbital cycles, then the potential for the creation of a high-resolution time scale is presented (e.g., D'Argenio et al. 1997; Strasser et al. 2006).

In the absence of precise geochronological control, it is recommended to refer to sequences in a relative sense, such as lower versus higher frequency, or lower versus higher rank, and interpret their relative stratigraphic significance based on criteria that can be observed in the rock record. Such criteria may include the geographic extent of unconformities, the magnitude of downstepping associated with offlap, the depth of fluvial-incised valleys, or the magnitude of facies change across sequence stratigraphic surfaces (e.g., Embry 1995; Catuneanu 2006). The applicability of these field criteria may vary with the case study, so any approach to hierarchy that is independent of the duration 
1. Model-independent methodology: (feasible to formalize)

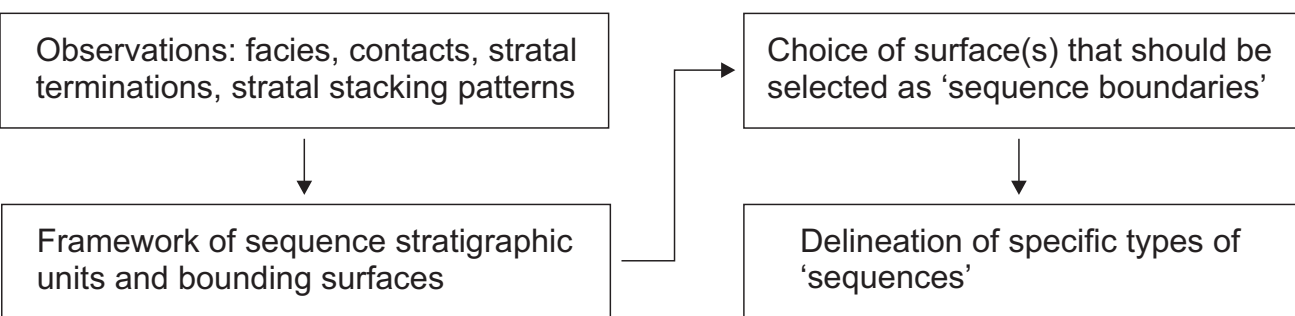

2. Model-dependent choices:

(not feasible to formalize)

'sequences' of cycles may be basin specific. This approach provides an empirical solution to a problem for which there is no universally applicable and accepted methodology for the definition of a hierarchy.

\section{Model-independent methodology}

The sequence stratigraphic approach relies on the observation of stratal stacking patterns and the key surfaces that bound successions defined by different stacking patterns. Construction of this framework ensures the success of the method in terms of its objectives to provide a process-based understanding of the stratigraphic architecture. This defines a model-independent methodology that honors all existing models but transcends their differences. Beyond the model-independent workflow, the interpreter may make modeldependent choices with respect to the selection of surfaces that should be elevated to the rank of sequence boundary (Fig. 19).

The surfaces that are selected as sequence boundaries vary from one sequence stratigraphic approach to another. In practice, the selection is typically a function of which surfaces are best expressed within the context of each situation, depending upon tectonic setting, depositional setting, types of available data and the scale of observation. The high degree of variability in the expression of sequence stratigraphic units and bounding surfaces requires the adoption of a methodology that is sufficiently flexible to accommodate the wide range of possible scenarios.

\section{Part two - Case studies}

\section{Nonmarine settings}

\section{Introduction}

Rivers are affected by controls directed from both upstream and downstream directions (Fig. 20). Sedimentation at any given time takes place within a 'buffer zone' that encompasses the maximum ability of the river to aggrade its floodplain (the upper limit of the buffer zone) and to scour the deepest part of its channel system (the lower limit), under prevailing conditions (Holbrook et al. 2006). The downstream end of this buffer zone is fixed by the presence of a 'buttress', which represents sedimentary base level. In the case of coastal rivers this is sea level. Channel-scale finingupward cycles (Fig. 21) represent sedimentation within the buffer zone. Sheet-scale and regional-scale cycles represent long-term shifts in the buffer zone.

Downstream controls include changes in sea level (in the case of a coastal river) or, in the case of an inland river within an entirely nonmarine basin, changes in elevation of the ridge over which the river flows to leave the basin. Changes in sea level affect only the lower few tens of kilometers of the system (Blum and Törnqvist 2000). Upstream controls include tectonism and climate change. Tectonic uplift may or may not counter the effect of the erosional lowering of the source area. Climate change affects discharge, sediment yield and seasonality. Upstream and downstream controls are typically unrelated and may be out of phase, and it is therefore not to be expected that the sequence boundaries and systems tracts of a nonmarine 


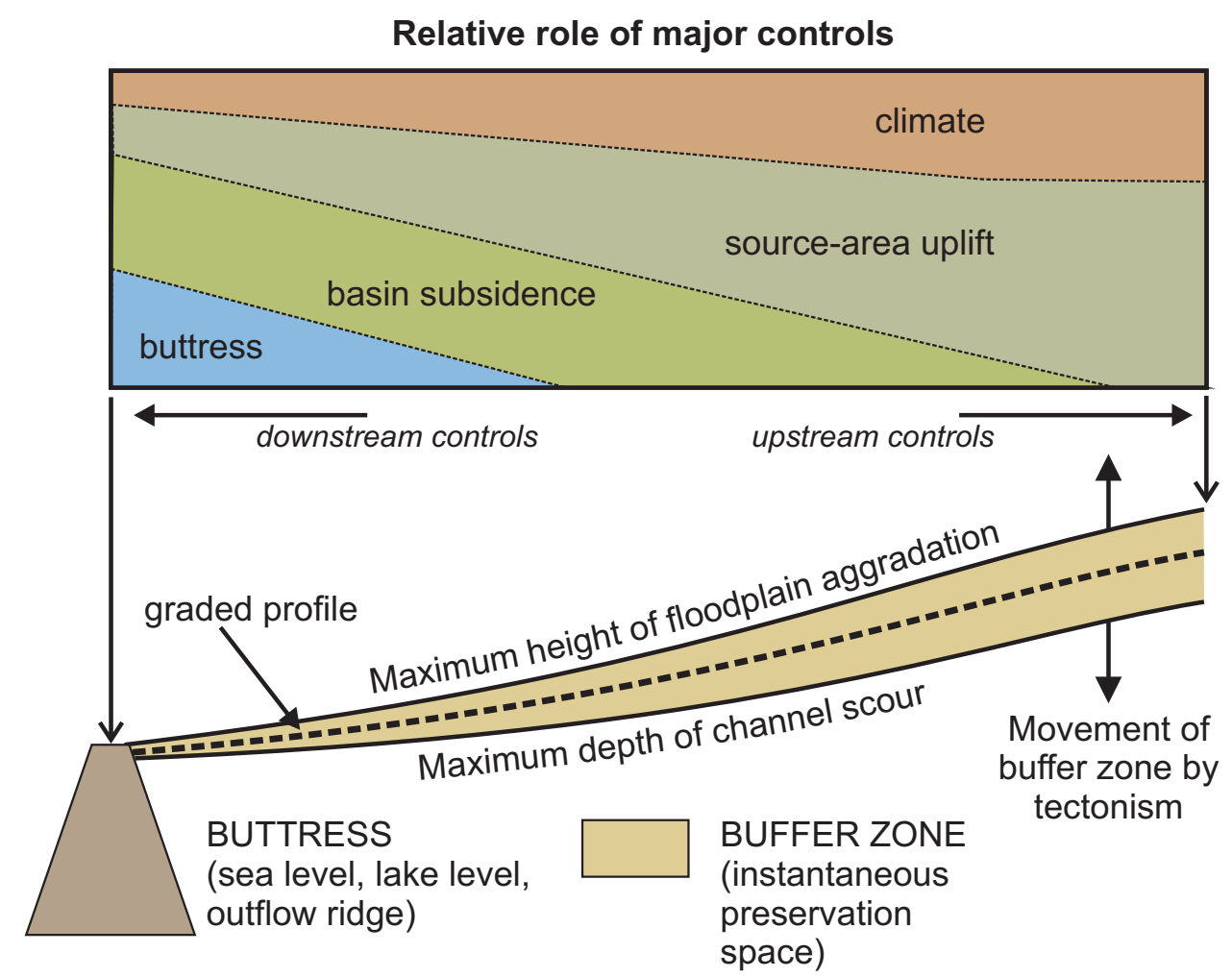

Fig. 20. The controls on accommodation in nonmarine environments. The concepts of the buttress and the buffer are adapted from Holbrook et al. (2006). The relative roles of the major controls on sedimentation were suggested by Shanley and McCabe (1994).

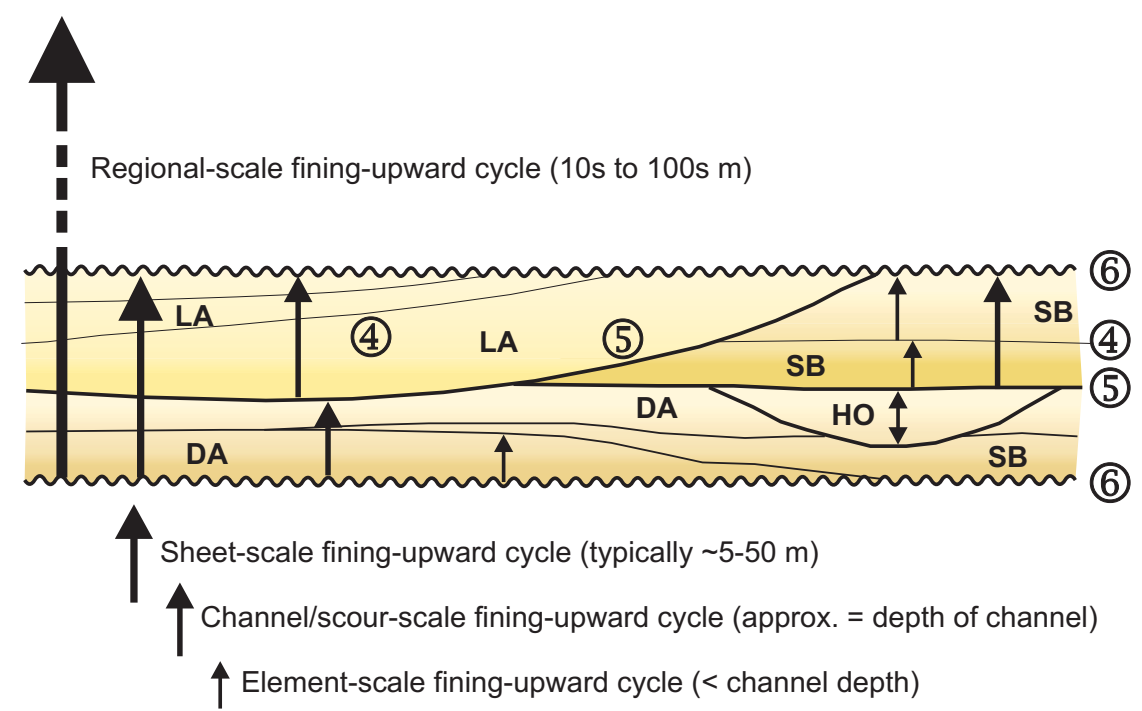

Fig. 21. Types of cycle in fluvial deposits. Cycle thickness is the first clue regarding the origin of the cycle, but is not definitive, given the wide range of scales of fluvial channels and depositional systems. Sheet-scale and regional-scale cycles may be capable of regional subsurface correlation based on well-log or seismic data, but the smaller-scale cycles have lateral extents of only a few tens to hundreds of metres, and may therefore not be traceable from well to well. Numbers refer to the classification of nonmarine bounding surfaces by Miall (1996): $4=$ surface bounding major bar deposit, $5=$ channel-scour surface, $6=$ regional stratigraphic surface, including sequence boundary. Two-letter architectural-element codes include LA = lateral-accretion deposit, $\mathrm{DA}=$ downstream-accretion deposit, $\mathrm{SB}=$ sand bedform element, $\mathrm{HO}=$ hollow element. 
system may be readily correlated to those of contemporaneous marine systems.

A rise in sea level elevates the downstream end of the buffer zone, creating new accommodation. This may cause transgression and flooding of a river, turning it into an estuary. With a high sediment load, however, a rise in sea level may be accompanied by an increase in aggradation. A lowering of sea level usually leads to a simple extension of the fluvial profile out across a gently dipping continental shelf, with little effect on inland reaches of the river, except possibly a change in channel style (Miall 1991; Schumm 1993). In the case of a narrow shelf, or where extreme sea-level fall takes place, lowering of the river mouth causes incision and the development, over time, of a broad coastal valley.

Many basins are bounded by tectonically active source areas. Episodic uplift of the source area results in a rejuvenation of river systems, and uplift of the buffer zone, and may also be accompanied by an increase in the calibre and quantity of the sediment load of the river. The ancient record contains many examples of fluvial profiles that coarsen upward over thicknesses of tens of metres as a result of a progressive increase in stream power and sediment load accompanying tectonic uplift (Miall 1996). Cyclic deposits of this type have been termed 'tectonic cyclothems' by Blair and Bilodeau (1988). Cessation of tectonic activity results in gradual erosional reduction of source-area relief and reduction in the quantity and calibre of the sediment load, yielding regional-scale fining upward cycles.

Cyclic successions are ubiquitous in fluvial deposits. Their presence reflects the fact that the fluvial environment is characterized by processes that tend to reproduce the same depositional results repeatedly. These repeated processes occur over a wide range of physical scales and time scales, but many are characterized by an initial pulse of high fluvial transport energy, which may be recorded as an erosion surface, followed by deposition of increasingly fine-grained sediment, with associated hydrodynamic sedimentary structures that decrease in scale (e.g., dune cross-bedding that becomes smaller in amplitude and passes upward into ripple cross-lamination). Successions that show an upward decrease in grain size, so called 'fining-upward cycles' are therefore common, and are commonly identified by 'bell-shaped' or 'blocky' wireline-log profiles (Fig. 21).

The basic relationship between base-level change and the cycle of aggradation and sedimentation in fluvial systems was first explored by Allen (1974). Modern sequence models have been proposed by Wright and Marriott (1993) and Shanley and McCabe (1994). Figure 22 is based on these studies. The paragraphs below discuss the development of the sedimentary facies and surfaces illustrated in this diagram, commencing with the basal sequence boundary.

\section{Forced regression}

Rivers in humid regions typically are characterized by an increase in discharge and a decrease in the caliber of the sediment load in a downstream direction. The work required to balance these changes leads to the development of a smooth longitudinal profile, termed a 'graded profile', which decreases in slope toward base level (the 'buttress' in Fig. 20). Valleys several kilometres wide and tens of metres deep may develop during a fall in base level. Pauses in this fall (e.g., periods of stable sea level) may allow the valley to widen, and the evidence of such episodes may be preserved in the form of terrace remnants along the valley walls. A widespread erosion surface develops across the coastal plain. On the interfluves (the elevated areas between major river valleys) the rate of erosion may be slow, allowing for the development of widespread soils. In arid to semi-arid settings, calcrete is commonly developed at such surfaces.

In nonmarine systems, the subaerial unconformity developed during forced regression is commonly taken as the sequence boundary. This surface represents the final position of the erosion surface immediately prior to the commencement of a new phase of base-level rise. The deep scour that occurs at the base of major rivers may cause this to form a prominent surface within a fluvial succession (Best and Ashworth 1997). The surface may cut down into a different facies succession, such as the transgressive or highstand shallow-marine or deltaic deposits of the preceding cycle, and the surface itself may be marked by a coarse lag deposit or evidence of extensive pedogenesis. However, in many systems deep scour is not in evidence. Miall and Arush (2001a) suggested the term 'cryptic sequence boundary' for the erosion surfaces that develop on low-relief alluvial plains where, in outcrop, the subaerial unconformity appears identical to any other channel-scour surface. Such cryptic sequence boundaries in fluvial successions might be identified by sudden changes in detrital composition, major shifts in fluvial dispersal directions, and evidence of early cementation in the deposits immediately below the subaerial unconformity, all of which are indications of the extended period of time represented by this surface, during which the fluvial system continued to evolve. 


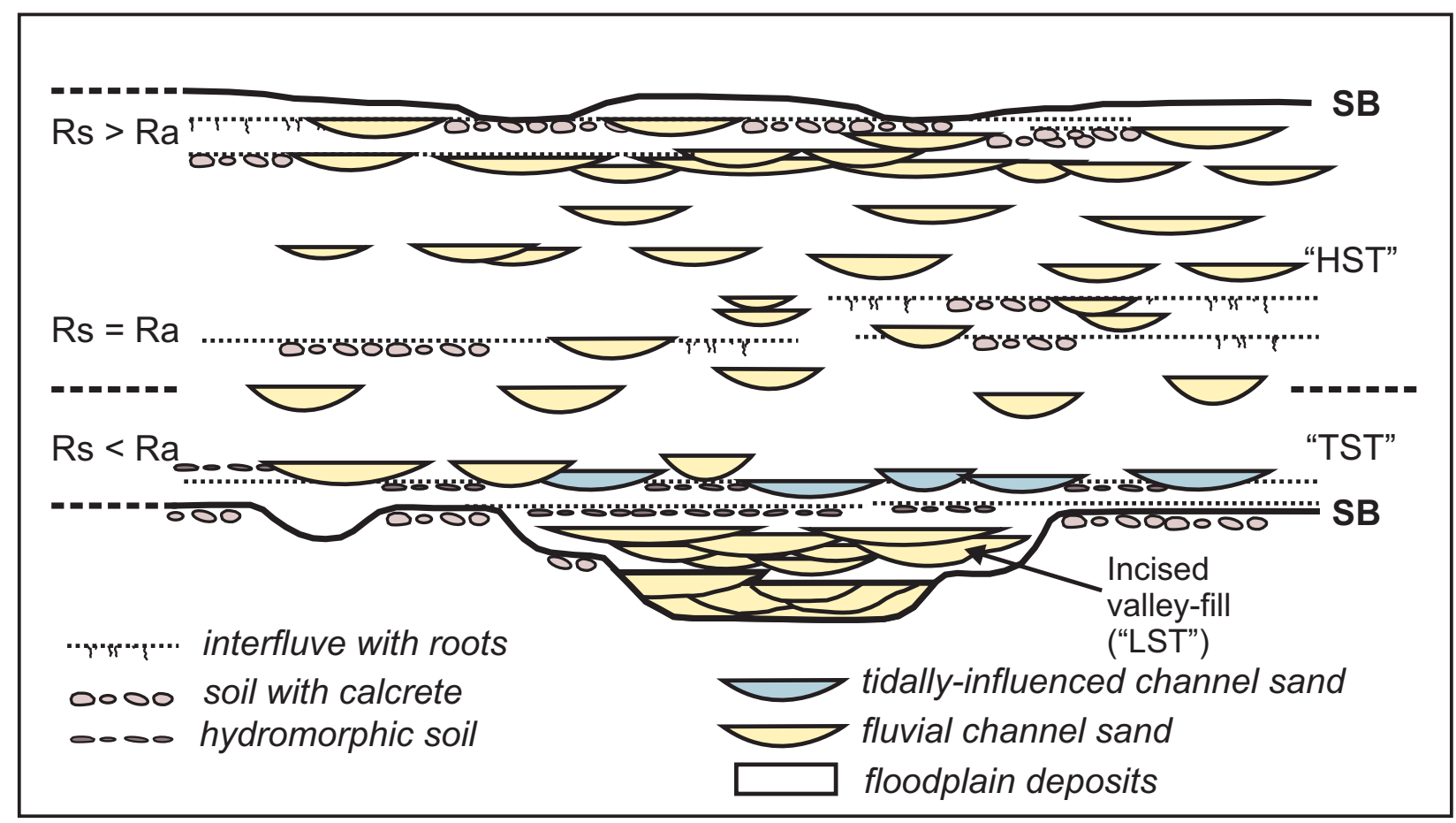

Fig. 22. Sequence model for nonmarine systems (adapted from Wright and Marriott 1993). Rs = rate of sedimentation, $\mathrm{Ra}=$ rate of accommodation generation. Conventional systems-tract acronyms are shown in quotes, because it may be questioned whether it is appropriate to use a terminology based on sea-level change for depositional systems that have no connection to the sea. For falling-stage and lowstand deposits, Currie (1997) suggested the term 'degradational systems tract', for transgressive deposits, 'transitional systems tract', and for highstand deposits, 'aggradational systems tract'. These terms provide analogous ideas regarding changes in accommodation and sediment supply and their consequences for depositional style.

\section{Lowstand normal regression}

Arise in base level generates increased accommodation and aggradation is likely to occur in the lower course of the river. The fill of an incised valley may commence with a complex of amalgamated channel-fill deposits, regardless of the fluvial style, reflecting an extended phase of channel reworking during a period when little new accommodation is being added to the fluvial profile. The rate of accommodation generation typically is less than the rate of sediment supply. Bar-top and floodplain deposits have a low probability of preservation during this phase. A sheet-scale topset with a 'blocky' vertical profile may be the result (Kerr et al. 1999).

The maximum regressive surface is typically placed at the contact between the amalgamated channel fills of the lowstand topset (low-accommodation conditions) and the overlying floodplain-dominated transgressive fluvial deposits (high-accommodation conditions; Kerr et al. 1999). Basinward, the maximum regressive surface may be traced along the base of the oldest central estuary facies. Upstream, the maximum regressive surface may onlap the subaerial unconformity.

\section{Transgression}

In the case of rivers draining into the sea, as the rates of base-level rise increase following the initial stage of creation of new accommodation, incised valleys become estuaries, with a range of depositional conditions ranging from fully marine at the mouth to fully nonmarine at the inland end of the estuary (Dalrymple et al. 1994). There will be a decrease in slope of the lower course of the river, leading to a reduction in competency and, consequently, in the grain size of the sediment transported and deposited. The rate of accommodation generation typically is greater than the rate of sediment supply. Rapid generation of accommodation may be reflected by high sedimentation rates, and provides ideal conditions for floodplain accumulation.

The limit of transgression is reached during the period when the rate of accommodation generation by rise in base level no longer outpaces the sedimentation rate at the shoreline. In predominantly nonmarine fluvial systems this may be indicated by the appearance of marine influence in otherwise typical fluvial deposits (Fig. 22). Marine ichnofacies may be present, 
and tidal influence may occur in the form of tidal bedding, reversing cross-bedding, sigmoidal bedding, and inclined heterolithic strata (Thomas et al. 1987). The widespread marine shales that commonly mark the maximum flooding surface in the marine realm may extend landward into the previously purely nonmarine succession. The thickest and most laterally extensive coals typically occur during this phase of the base-level cycle (Bohacs and Suter 1997). Channel complexes may be encased in thick floodplain fines and exhibit little lateral interconnectedness. Soils are likely to be immature. Hydromorphic soils, commonly characterized by siderites, are also typical of this phase of sedimentation (Wright and Marriott 1993).

\section{Highstand normal regression}

At the end of the phase of base-level rise, the rate of accommodation generation slows, leading to a reduction in the ability of fluvial systems to aggrade. Channel complexes become more laterally interconnected, developing broad sandstone sheets and, at the same time, channel scour reduces the preservation potential of floodplain deposits, resulting in increased sand- stone/shale ratios relative to the underlying systems tract. Soils have more time to develop and become more mature. Those that develop on interfluves, well away from areas of active fluvial erosion, may survive to become the subaerial unconformity during the next phase of base-level fall.

\section{Case study: The Castlegate Sandstone (Upper Cretaceous), Book Cliffs, Utah}

The Castlegate Sandstone is part of the clastic wedge derived from the growing Cordilleran orogen, which prograded eastward into the Western Interior Seaway between the Late Jurassic and the Eocene (Miall et al. 2008). It is particularly well exposed in the Book Cliffs of central Utah, between Price and Green River (Figs. 23, 24).

There are two scales of sequences in this succession, long-term sequences, such as that comprising the Castlegate Sandstone, with durations of about $5 \mathrm{Myr}$ (sequences 1 to 3 of Fig. 23; Olsen et al. 1995), and high-frequency sequences in the Neslen Formation (not shown in Fig.23), each representing less than

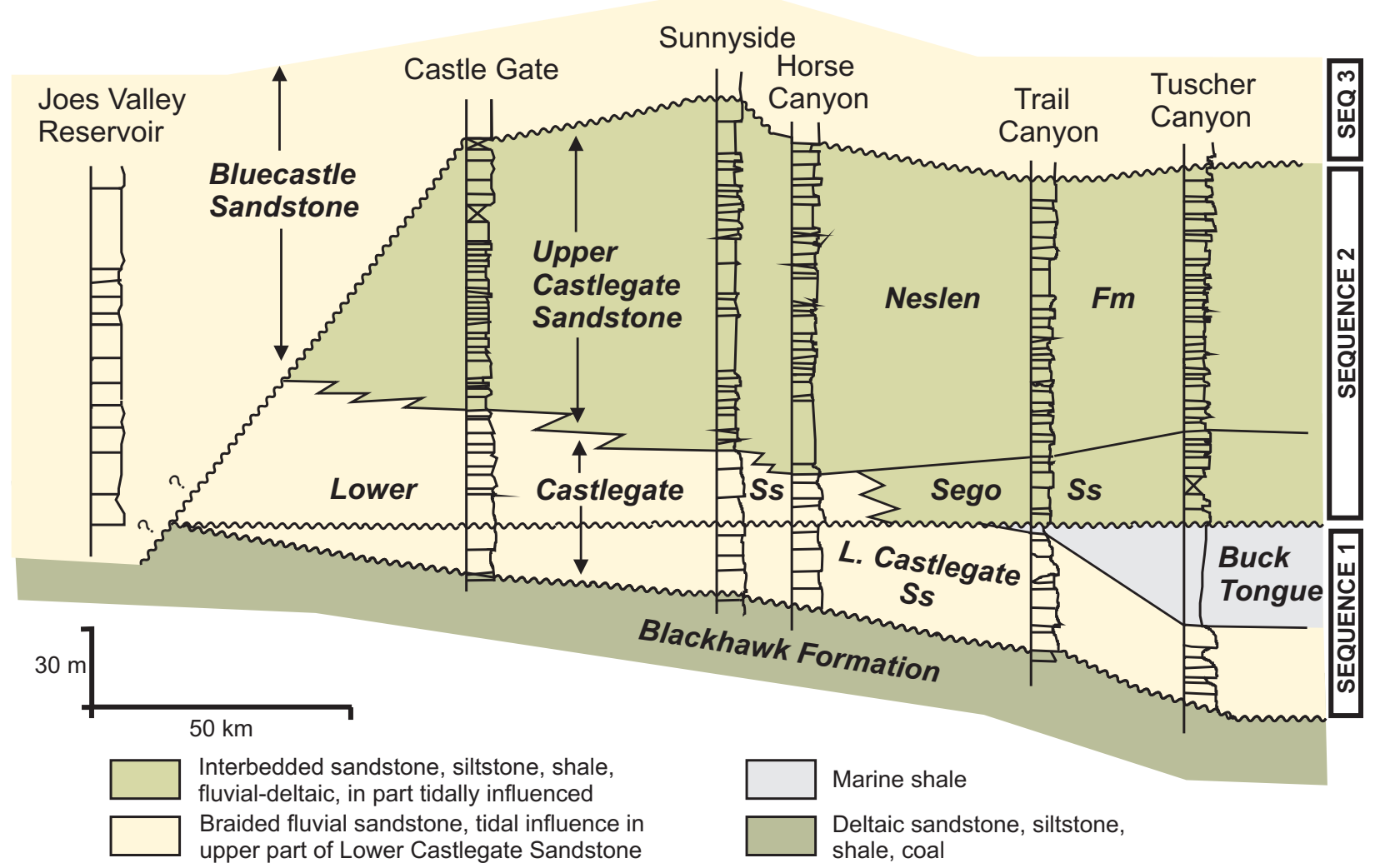

Fig. 23. Stratigraphy of the Castlegate Sandstone. From Miall and Arush (2001b), as modified from Olsen et al. (1995) and Yoshida et al. (1996). 


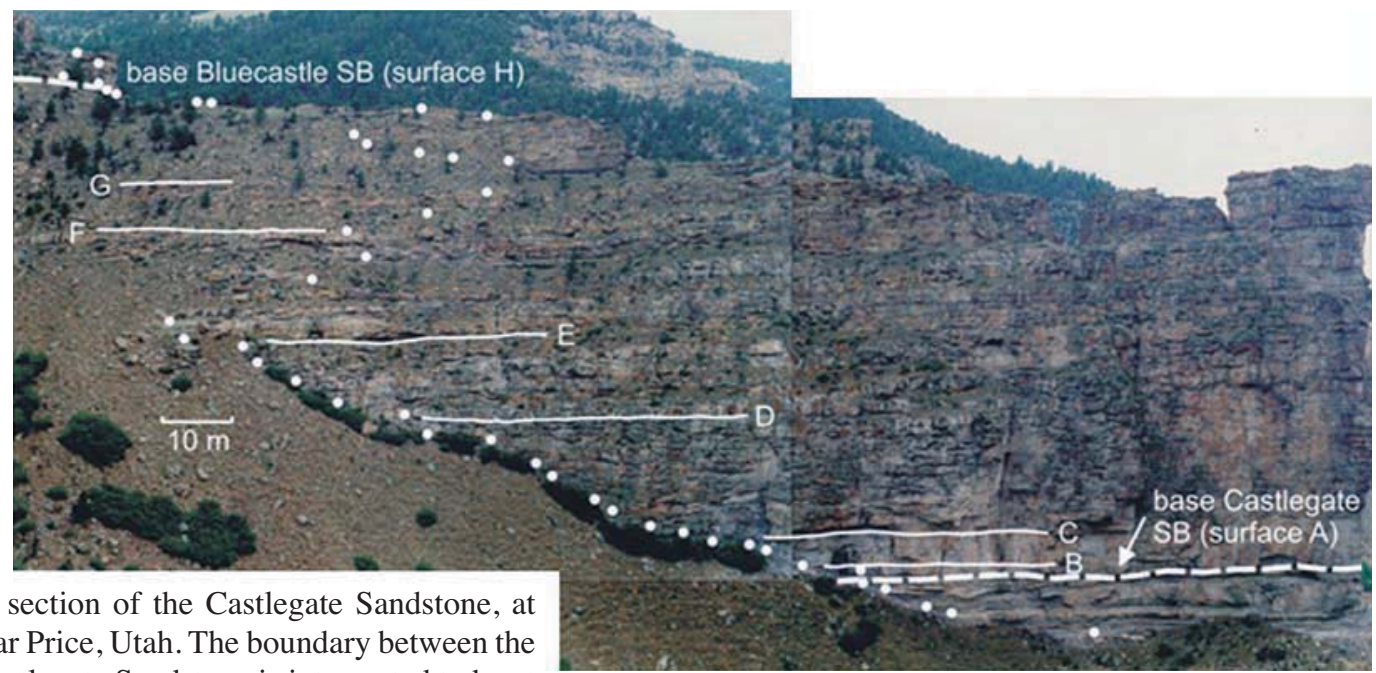

Fig. 24. The type section of the Castlegate Sandstone, at the Castle Gate, near Price, Utah. The boundary between the upper and lower Castlegate Sandstone is interpreted to be at surface D (Miall and Arush 2001b).

1 Myr. Willis (2000) and Yoshida (2000) demonstrated the unconformable truncation of the Buck Tongue, a unit of marine shale extending westward from the centre of the Western Interior Basin in Colorado. The Buck Tongue represents approximately a million years of sedimentation. Its westward truncation implies the presence of a significant unconformity within the updip portion of the Lower Castlegate Sandstone. $\mathrm{Nu}-$ merous erosion surfaces are present within the braided sheet sandstones that comprise most of the Castlegate Sandstone, but most of these are channel scour surfaces (bounding surface type 5 of Fig. 21). Miall and Arush (2001b) correlated the unconformity with surface D at the type section of the Castlegate Sandstone (Fig.24) on petrographic grounds.

Surface D is a good example of a cryptic sequence boundary which, although representing several million years of missing time, is indistinguishable in outcrop
Fig. 25.

The sequence boundary at the base of the Castlegate Sandstone, At the Castle Gate type section.

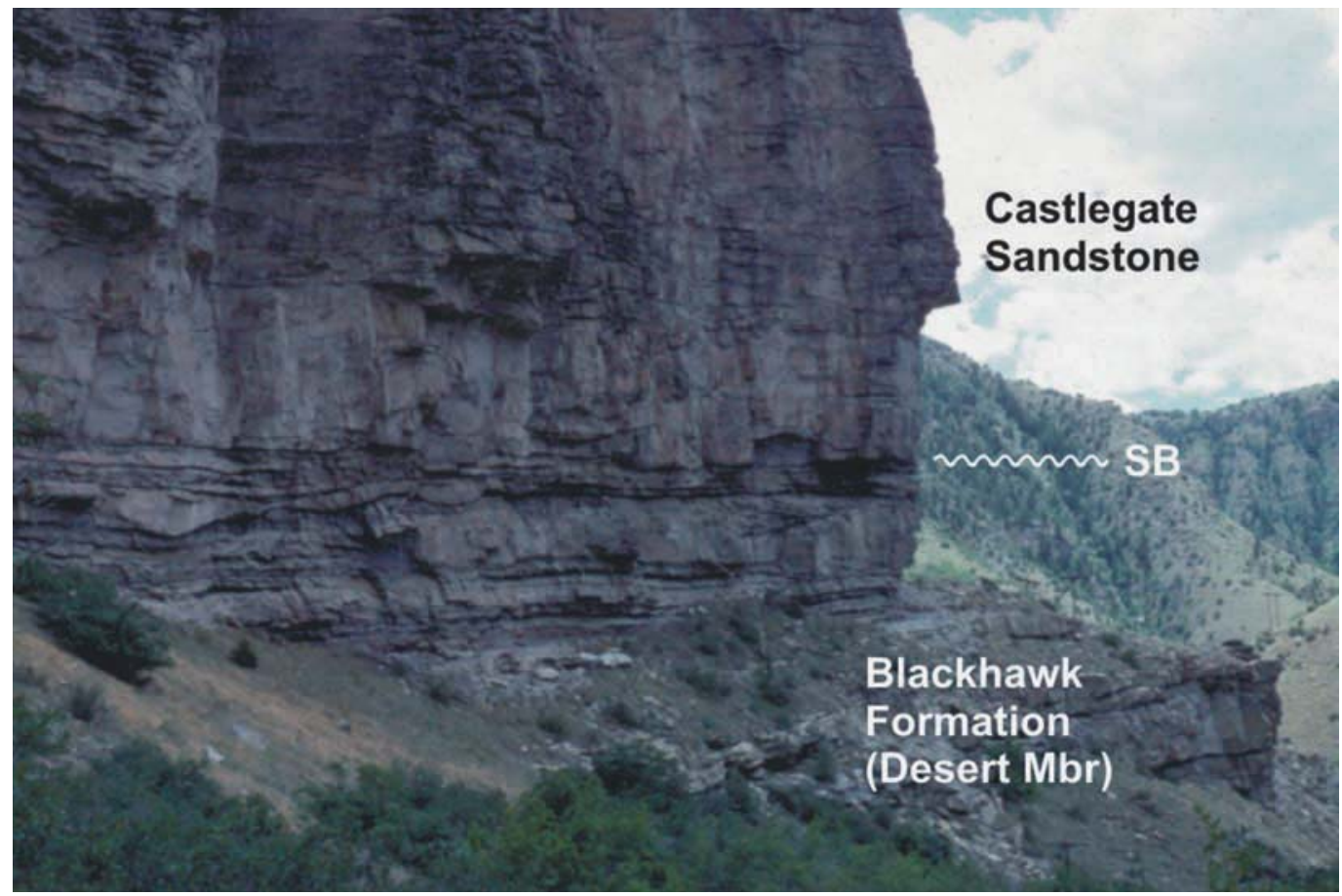




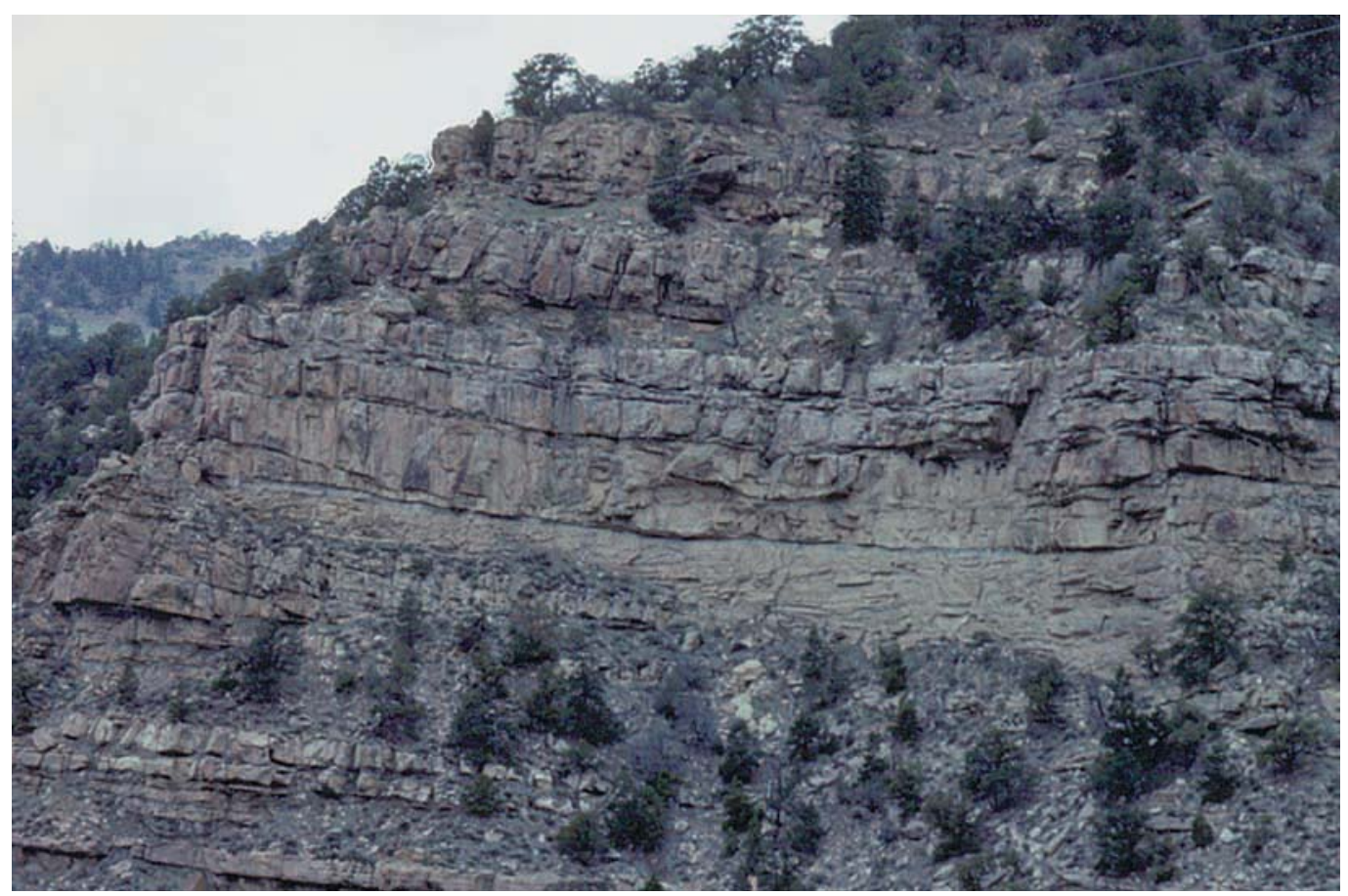

Fig. 26. Outcrop of the Castlegate Sandstone $10 \mathrm{~km}$ east of the type section. Recessive-weathering beds just below the centre of the field of view consist of interbedded sandstones and shales displaying inclined heterolithic stratification, interpreted as indicating tidal influence. The beds above and below are typical braided sheet sandstones.

from other channel scour surfaces. The type of deep scour hollows that Best and Ashworth (1997) suggested would characterize many nonmarine sequence boundaries is not present in this system. The Castlegate rivers probably combed continuously across the alluvial plain, resulting in a widespread erosion surface that can be traced down-dip for more than $150 \mathrm{~km}$.

The base of the Castlegate Sandstone (lower right corner of the type section: Fig. 24, and in a closer view in Fig. 25) is marked by a distinct change in facies from the coal-bearing, heterolithic, meandering-stream deposits of the underlying Blackhawk Formation to the coarser-grained, braided sheet sandstones of the Castlegate. The sequence boundary is clearly a surface of erosion, with erosional relief of a few centimeters, followed by a lag deposit of wood fragments, and scattered dinosaur bone fragments.

Olsen et al. (1995) and Yoshida (2000) showed that the Upper Castlegate Sandstone contains abundant evidence of tidal influence, in the form of tidal bedding and inclined heterolithic stratification (Thomas et al. 1987) (Fig. 26). This part of the succession therefore corresponds to the TST of Shanley and McCabe (1994) or 'transitional systems tract' of Currie (1997).

\section{Coastal and shallow-water siliciclastic settings}

\section{Introduction}

Sequence stratigraphy is arguably easiest to apply in coastal to shallow-water siliciclastic settings, where the relationship between stratal stacking patterns and shoreline trajectories is most evident (Fig. 3). All sequence stratigraphic surfaces and systems tracts may form in these settings, although they may not necessarily occur together within the same stratigraphic section.

\section{Forced regression}

The deposits of forced regression (i.e., the FSST) display a stacking pattern characterized by forestepping and downstepping at the shoreline, interpreted as the result of relative sea-level fall (Figs. 3, 27). Criteria for the recognition of forced regressive deposits include: separation (detachment) between successive paleocoastlines; presence of sharp-based shoreface/delta front deposits; presence of progressively shallower clinoforms in a distal direction; occurrence of long-distance regression; absence of fluvial and coastal plain/ 

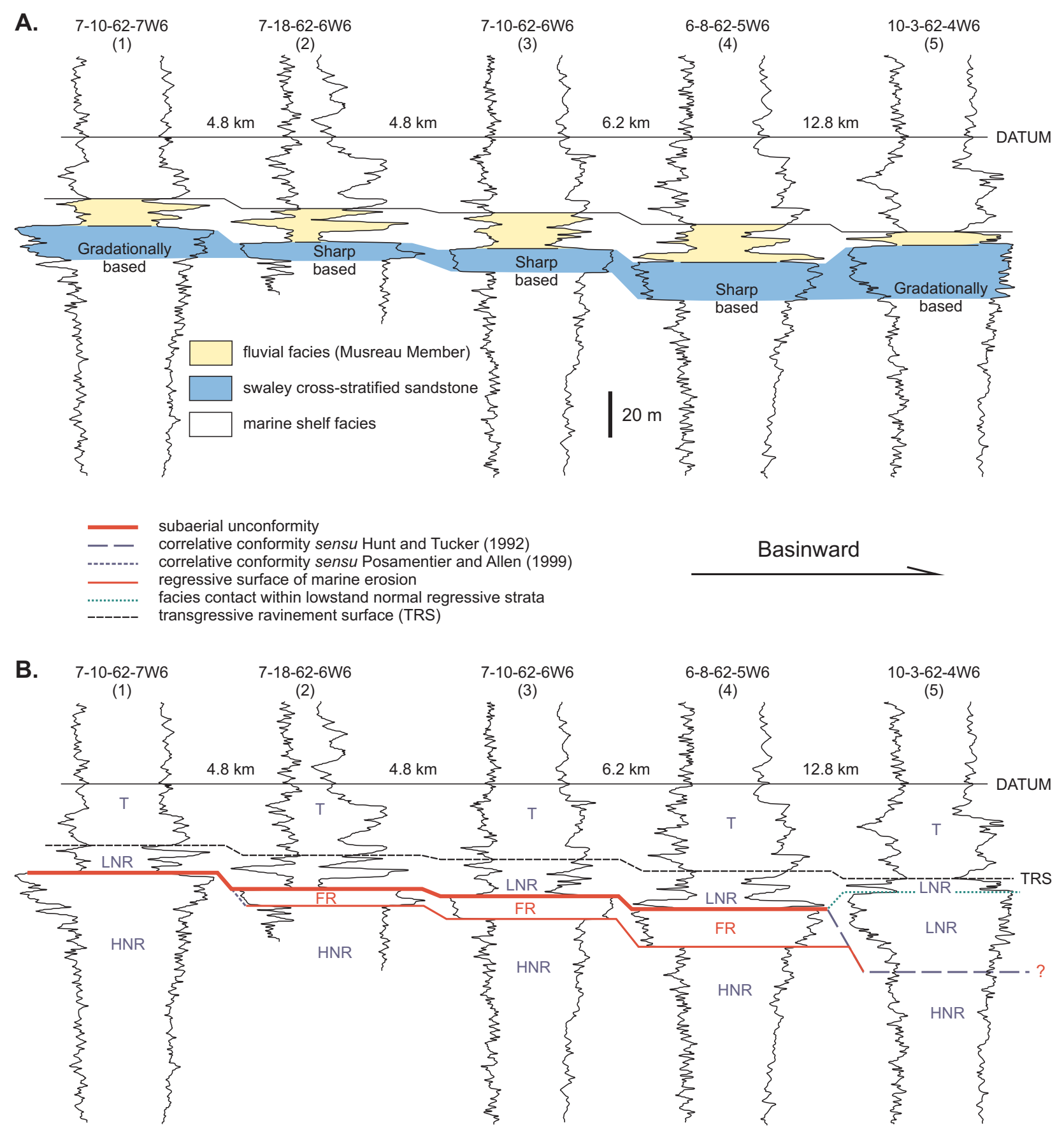

Fig. 27. Sequence stratigraphic interpretation of the swaley cross-stratified sandstone of the Kakwa Member (Cardium Formation), and adjacent units (from Catuneanu et al. 2010; modified after Plint 1988). The datum is represented by a flooding surface within the Muskiki marine shale. A. Sedimentary facies. B. Sequence stratigraphic interpretation. The interpretation is based on the following observations: 1 . the shoreface displays coarsening-upward trends in all five wells; 2 . the shoreface is gradationally based in wells (1) and (5), and it is sharp-based in wells (2), (3) and (4); 3. the top of the shoreface downsteps from well (1) to well (4), and upsteps from well (4) to well (5); 4. the sharp-based shoreface thins out toward the basin margin; and 5. the shoreface is overlain by nonmarine facies in all five wells. The gradationally-based shoreface indicates normal regression (highstand to the left; lowstand to the right), whereas sharp-based shoreface is diagnostic for forced regression. These criteria afford the separation of normal from forced regressive deposits in the absence of seismic data. FR - forced regressive; HNR - highstand normal regressive; LNR - lowstand normal regressive; T - transgressive. 
delta plain topsets at the top of forced regressive foresets; truncation of forced regressive foresets by a seaward-dipping unconformity; increase in average sediment grain size in forced regressive foresets in a basinward direction; and presence of 'foreshortened' stratigraphic successions (Posamentier and Morris 2000).

Forced regressive deposits typically build the dominant systems tract of sequences that form on continental shelves during periods of profound icehouse climatic and eustatic forcing (Fig. 17). This is because glacioeustatic changes in sea level are strongly asymmetrical, with brief stages of fast sea-level rise and prolonged stages of slower sea-level fall (Bard et al. 1990). At the same time, both the magnitudes and the rates of sea-level change are higher in an icehouse world as compared to a greenhouse regime. Sequences of an icehouse affinity are typically less than $50 \mathrm{~m}$ thick and often organized in stacks of several in succession, suggesting a relation to orbital forcing (e.g., Naish et al. 2001; Fielding et al. 2008; Fig. 17). Examples of such icehouse sequences have been documented in studies of Neogene continental margin successions around Antarctica (Bartek et al. 1991, 1997; Fielding et al. 2001; Naish et al.2001), from Plio-Pleistocene successions in New Zealand (Naish and Kamp 1997; Saul et al. 1999), the Miocene Chesapeake Group of eastern USA (Kidwell 1997), the Miocene of western Chile and Ecuador (Di Celma and Cantalamessa 2007; Cantalamessa et al. 2007), and from Lower Permian strata in the Sydney Basin of eastern Australia (Fielding et al. 2006).

\section{Normal regression}

The deposits of normal regression display a stacking pattern characterized by forestepping and upstepping at the shoreline, interpreted as the result of positive and overfilled accommodation. Normal regressions are driven by sediment supply and occur during relative sea-level rise, either before or after transgressions; the two types of normal regression are designated as 'lowstand' (i.e., the LST) and 'highstand' (i.e., the HST) respectively. Shoreline trajectories are different during lowstand versus highstand normal regressions (Fig. 4), reflecting accelerating or decelerating rates of creation of accommodation (e.g., fig. 19 in Catuneanu et al. 2009). During normal regressions, fluvial and coastal plain/delta plain topsets aggrade and prograde at the top of shallow-water foresets (Figs. 6-8 and 27).

\section{Transgression}

The deposits of transgression (i.e., the TST) display a stacking pattern characterized by backstepping at the shoreline, interpreted as the result of positive and underfilled accommodation. During transgression, most riverborne sediment is trapped within rapidly aggrading and backstepping fluvial and coastal systems, while the shallow marine environment is often starved of sediment (Loutit et al. 1988; Van Wagoner et al. 1990). The decrease of sediment supply to the marine environment during transgression may result in the formation of subaqueous unconformities, expressed as 'hiatal surfaces' in the rock record (Galloway 1989). Such unconformities may be accompanied by the formation of hardgrounds or firmgrounds marked by substrate-controlled ichnofacies (e.g., Pemberton and MacEachern 1995). Transgressive deposits are recognizable on seismic sections where condensed sections and/or marine or coastal onlap are observed (Fig. 8), but also in outcrop or well-log data sets (Figs. 6, 7, 15, 16).

\section{Case study: The Yegua Formation (Eocene), Gulf of Mexico}

The Yegua Formation records a significant terrigenous clastic depositional episode along the entire northern and northwestern continental margin of the Gulf of Mexico Basin (Galloway et al. 2011). The episode is recorded by a sand-bearing genetic stratigraphic sequence bounded by maximum-flooding surfaces within the regional marine Crockett (Texas) and Cook Mountain (Louisiana) Shales and the Moody's Branch Marl (Fig.28). The depositional episode extended from about 38 to 36.1 Ma (Paleo-Data 2009) within late Middle to Late Eocene Standard Foraminiferal Zone P15. The Yegua section reflects, in stratal stacking pattern and consequent log response, a typical Gulf Coast Cenozoic succession of progradational and aggradational facies, capped by relatively thin back-stepping/transgressive deposits (Fig. 28) (Frazier 1974). Sedimentation rates were high; the northern Gulf of Mexico depocentre contains 0.5 to $>1 \mathrm{~km}$ of sediment deposited within about 2 years. This is one of the highest rates of sediment accumulation recorded in the Gulf Cenozoic section (Galloway et al. 2011). The Yegua coastal plain prograded onto a deep, foundered continental shelf/ramp that was constructed by progradation of the Early Eocene Upper Wilcox sequence. Regional studies (Edwards 1991; Meckel and Galloway 1996; Galloway et al. 2000) delineate a large, fluvial-dominated delta system that constructed the upper Texas coastal plain depocentre.

Fang (2000), in a sub-regional study area lying in the southeast Texas depocenter, recognized 15 physical 
Fig. 28. Representative electrical $\log$ of fully developed mid-dip Yegua genetic sequence. Log markers divide the sequence into 14 genetic packages. Interpreted origin of each log marker is shown in the right column. Modified from Fang (2000).

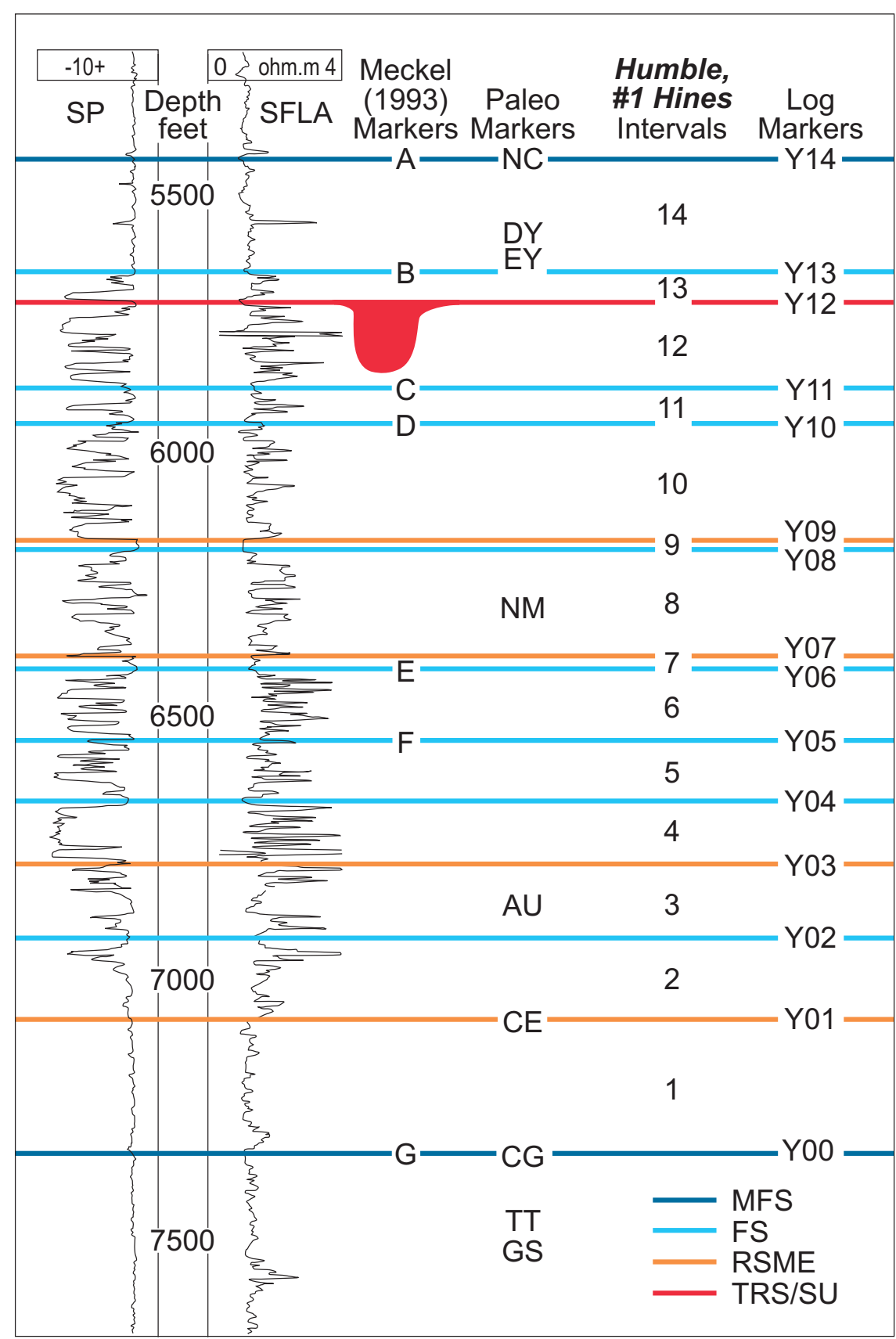

stratigraphic markers, labeled Y00-Y14, that could be correlated within the study area (Fig. 28). Markers Y00 and Y14 are the maximum-flooding surfaces that bound the Yegua genetic stratigraphic (Fig. 28). Graphic correlation displays chronostratigraphic terraces, recording condensation, non-deposition, and/or mild erosion, at each of these horizons (Fang 2000). These constitute two of only three demonstrable chronostratigraphic discontinuities (excluding fault and slump planes) found within the Yegua interval. Most of the markers, including Y02, Y04, Y05, Y06, Y08, Y10,
Y11, and Y13, are flooding surfaces bounding parasequences and parasequence sets that range from several metres to around a hundred metres in thickness. Y01 corresponds to the Last Appearance Datum (LAD) of benthic foraminifer Ceratobulimina eximia and is the traditional base of the Yegua Formation. It is characterized by the appearance of the first sand or siltstone interval, which is commonly sharp-based in updip and outcrop sections. It is interpreted as a possible regressive surface of marine erosion. Surfaces Y00 through Y03 coalescence into a condensed section downdip 

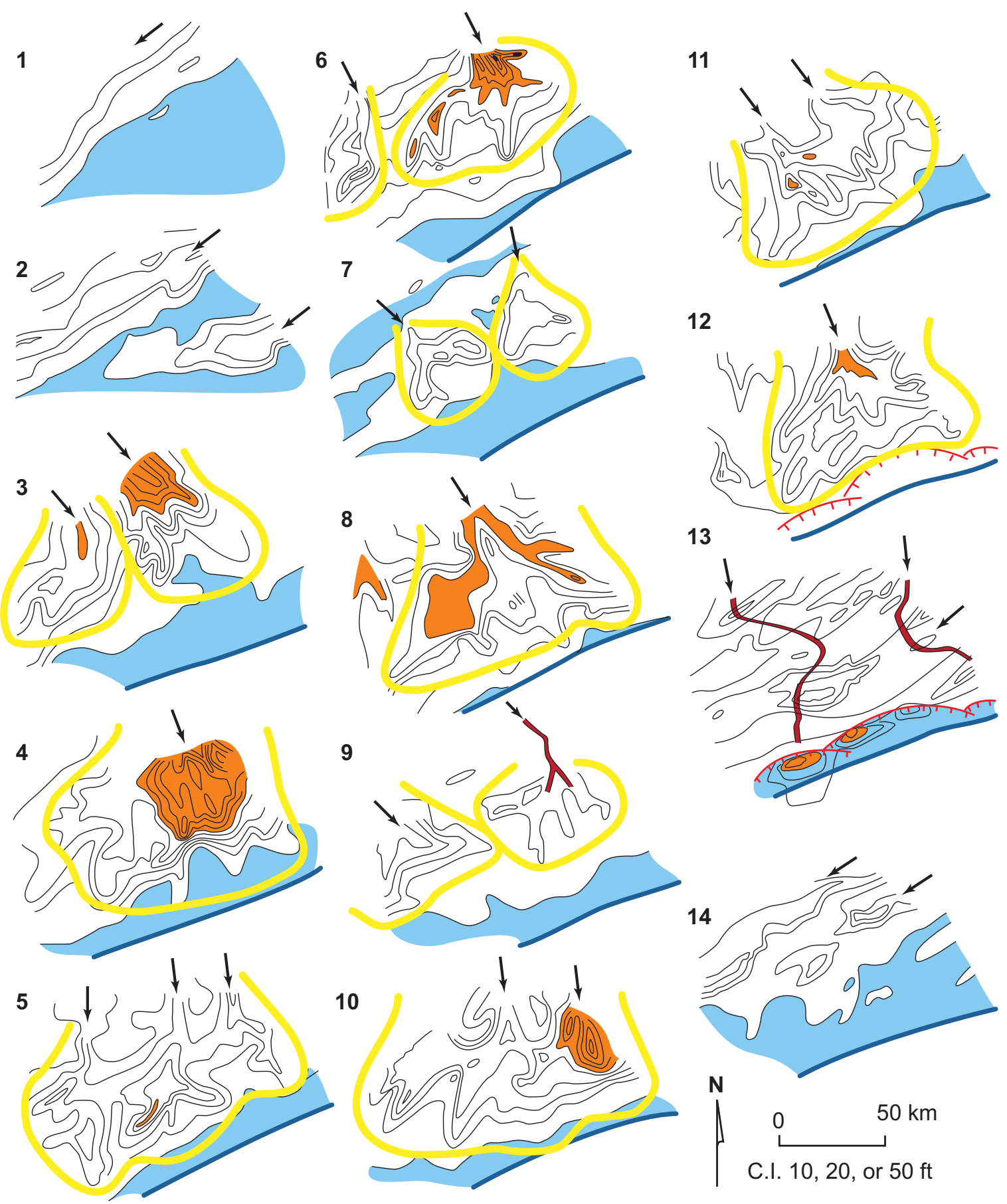

EXPLANATION

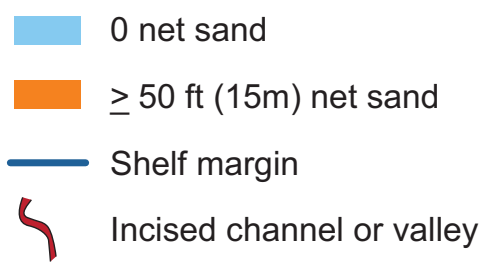

TT Slump

$\downarrow$ Sand input axis

Delta lobe outline

Fig. 29. Net sand isopach maps for each of the 14 Yegua genetic packages showing interpreted delta lobes, inferred fluvial input axes, and shelf edge position. Note contour interval varies from map to map. Compiled from Fang (2000). 
toward the paleo-shelf edge. Three offlapping parasequence sets compose the basal Yegua regression onto the Y00 maximum-flooding surface. This succession records normal regression within the highstand systems tract. The regressive succession culminates in marker Y04, which records a mildly erosional event up dip, where it is overlain by sharp-based sand bodies of distributary and fluvial channel fills. Down dip, the basal Yegua sand body lies above the marker, which is interpreted to be a possible regressive surface of marine erosion. Two aggradational parasequence sets, bounded by flooding surfaces Y04, Y05, and Y06, form the bulk of the remaining lower Yegua succession and record a resumption of normal regression. Marker Y06 records a prominent and regionally correlative surface of transgression of the Yegua coastal plain. A third possible chronostratigraphic break as demonstrated by graphical correlation lies at or near Y06.

Y07 evidences rejuvenation of Yegua sediment supply and coastal regression. The overlying sand facies display either blocky, upward-fining or sharp-based, serrate log patterns; the shaley interval between flooding surface Y06 and Y07 is typically replaced updip by thick, upward-fining sand bodies. Consequently, the interval between Y06 and Y07 pinches out. Biofacies show abrupt shoaling across Y07, which is interpreted to be a well-developed regressive surface of marine erosion. Neither widespread subaerial exposure nor valley incision is demonstrated by the data. Regression was, however, forced by relative sea-level fall. Y08 records a marine flooding surface and increase in water depth within what is the thickest shale tongue in the Yegua Formation. Y09 records a second forced regression with prominent biofacies shoaling and widespread presence of sharp-based sand bodies above the shaley interval. Y10 and Y11 are both flooding surfaces, associated with neritic faunas, widespread thin shale beds, and inter-regional markers.

Marker Y12 is unique. Abrupt shoaling occurs across the demonstrably erosional surface. Thick, upward-fining sand bodies cut several tens of metres from this surface into underlying strata. These highly erosional channels or small valleys extend across the muddy shelf to the paleo-shelf edge. In most mid- and up-dip wells, the marker is capped by a thin, laterally continuous, sharp-based sand unit. The surface is interpreted to be a combined subaerial unconformity and superimposed transgressive ravinement surface. Marker Y13 is a regionally correlative marine flooding surface that caps Yegua sand bodies in mid- and down-dip sections. It is chronostratigraphically significant, demark- ing the LAD of Eponides yeguaensis. The LAD of Discorbis yeguaensis occurs just above the surface. Overlying marker Y14, characterized by the LAD of Nonionella cockfieldensis, is the regional maximumflooding surface that caps the Yegua episode.

The upper Yegua, extending from Y06 to Y13, records a robust phase of normal depositional regression, punctuated by at least three forced regressive events, followed by backstepping transgression, and terminated by flooding and sediment starvation across the northern GOM continental margin. At the level of chronostratigraphic resolution possible, both the upper and lower bounding maximum flooding surfaces are documented disconformities that can be accurately dated. In contrast, internal forced regressive surfaces and the fluvial erosion surface do not create measurable temporal discontinuities (Fang 2000).

The 15 marker surfaces provide a high-resolution stratigraphic framework of 14 genetic units for mapping and interpreting the depositional history of the Yegua. Given the ca. 2 Myr duration of the episode, each records on the order of 125,000 years. Figure 29 shows mapped sand distribution in the 14 defined intervals. Mid to deep shelfal shale-dominated intervals 1 and 2 display thin, linear sand bodies that extend NE-SW along depositional strike. The next ten intervals display digitate sand patterns that record a succession of stacked delta lobes that repeatedly prograded from NW to SE across the study area, showing ongoing lateral shifts in sand input axes, lobes, and depocentres. Interval 13 , bounded below by the composite subaerial unconformity and transgressive ravinement surface, is distinct. Two narrow valleys extend across the shelf and connect downdip to locally thick (up to $50 \mathrm{~m}$ ), pod-shaped, paleo-shelf edge sand successions. These are small, growth-faulted shelf-edge deltas and their upper slope turbidite aprons were deposited during the temporary lowstand and comprise the lowstand systems tract. Above the transgressive ravinement surface, neritic shales contain thin, strikeelongate, transgressive shelf sands. Interval 14, the last gasp of back-stepping deposition, is shale dominated, but contains strike-elongate belts and pods of inner shelf, shoreface, and strandplain sand.

The composite record of the Yegua episode can be summarized as (1) initial muddy shelf and shore-zone progradation, (2) and extended period of repeated delta lobe progradations (sometimes normal, sometimes forced), abandonment, and transgression, (3) a terminal pulse of lowering base level resulting in deep fluvial channel incision across about $50 \mathrm{~km}$ of exposed 
shallow shelf accompanied by accumulation of small shelf margin delta lobes, and (4) terminal backstepping transgression. The northern Gulf margin was a broad sediment-starved continental shelf both before and after Yegua deposition.

\section{Deep-water siliciclastic settings}

\section{Introduction}

Acquisition of 3D volumes of seismic data compensates for the difficulty of observing deep-water processes and products in modern environments (e.g., Posamentier and Walker 2006; Weimer and Slatt 2007). Most depositional elements that form in the deep-water setting develop over km-size scales in plan view, which is why few outcrop-based studies can replace or rival the imaging generated by the high-resolution 3D seismic data. This, together with the lack of accessibility of the deep-water present-day environment, renders the seismic data a unique role into the understanding of the deep-water setting, arguably more important than in the case of any other depositional setting.

The application of sequence stratigraphy to the deep-water setting is challenging because: (1) there is potential for physical disconnection between the deepwater portion of sequences and their fluvial to shallowwater equivalents, commonly as a result of nondeposition or sediment instability and erosion in the shelf edge to upper slope areas; (2) the time control to correlate the deep-water and the shallow-water portions of sequences is typically inadequate; (3) deposition in the deep-water setting is controlled primarily by gravity flows and mass transport processes, which may result in lateral rather than vertical stacking of depositional elements and systems tracts; and (4) the evidence of relative sea-level change is only indirect in the deepwater setting. In spite of these challenges, significant progress has been made in the definition of sequence stratigraphic models that describe the relationship between the cyclic change in the type of deep-water depositional elements and the corresponding changes in accommodation and shoreline trajectories on the shelf (e.g., Posamentier and Kolla 2003; Catuneanu 2006; Fig. 30).

The cyclic nature of siliciclastic deposition in deep water has been emphasized in numerous case studies and syntheses (e.g., Weimer 1991; Winker and Booth 2000; Posamentier and Kolla 2003; van der Merwe et al. 2010). A cycle of sedimentation in the deep water starts with the activation of shelf-edge repositories during relative sea-level fall, when a decrease in accommodation on the shelf results in an increase in sediment supply to the deep-water environment. The cycle ends with the gradual deactivation of the shelfedge staging areas during relative sea-level rise, when renewed accommodation on the shelf is able to trap the majority of terrigenous sediment within fluvial to shallow-water systems.

Changes in accommodation on the shelf, as well as in the location of the coastline, control both the volume and the grain size of the riverborne sediment delivered to the deep-water setting. Sediment supply may also be modified by climate and tectonism in the source areas, the size and the energy of the rivers that bring sediment to the coastline, as well as by the width of the continental shelf. In the case of narrow shelves, sediment supply to the deep-water environment may be higher during all stages of the relative sea-level cycle; however, the general trends are maintained in the sense that the lowest volume and the finest sediment will still accumulate during times of highest accommodation on the shelf, whereas the largest volume and the coarsest sediment will still be delivered during times of lowest accommodation on the shelf.

Typically, three sequence stratigraphic surfaces are mappable regionally within the deep-water setting: the two types of correlative conformity and the maximum flooding surface (Posamentier and Kolla 2003; Catuneanu 2006; Figs. 31, 32). These surfaces relate to important phases in the evolution of the deep-water system. The correlative conformity of Posamentier and Allen (1999) marks the onset of high sediment supply to the deep basin, which typically starts with mud-dominated gravity flow and mass transport deposits. The correlative conformity of Hunt and Tucker (1992) corresponds to the top of the coarsest sediment in the deep-water basin, which typically forms the best petroleum reservoirs. The maximum flooding surface marks the timing of the minimum sediment delivery to the deep basin, and it is typically placed at the heart of regionally extensive condensed sections.

A deep-water sequence includes the equivalents of forced regressive, lowstand normal regressive, transgressive and highstand normal regressive deposits on the shelf (Fig.30). The following are generalized trends that describe a cycle of deep-water sedimentation. Departures from this model may occur as a function of shelf width, sediment supply, and patterns of sediment transport (e.g., Porebski and Steel 2006; Covault et al. 2007). 
Fig. 30. Dominant types of gravity-flow deposits that form the submarine fan complex in a deep-water setting (modified from Posamentier and Kolla 2003; Catuneanu 2006).

(1) mudflow deposits; (2) highdensity turbidites and/or grainflow deposits; (3) low-density turbidites. The relative contribution of hemipelagic sediment to the rock record is inversely proportional to the volume of terrigenous sediment delivered to the deep-water setting. Abbreviations: RSL - relative sea level; HNR - highstand normal regressive deposits; FR - forced regressive deposits; LNR - lowstand normal regressive deposits; $\mathrm{T}$ - transgressive deposits; CC $^{*}$ - correlative conformity sensu Posamentier and Allen (1999); CC ${ }^{* *}$ - correlative conformity sensu Hunt and Tucker (1992); MRS - maximum regressive surface; MFS maximum flooding surface.

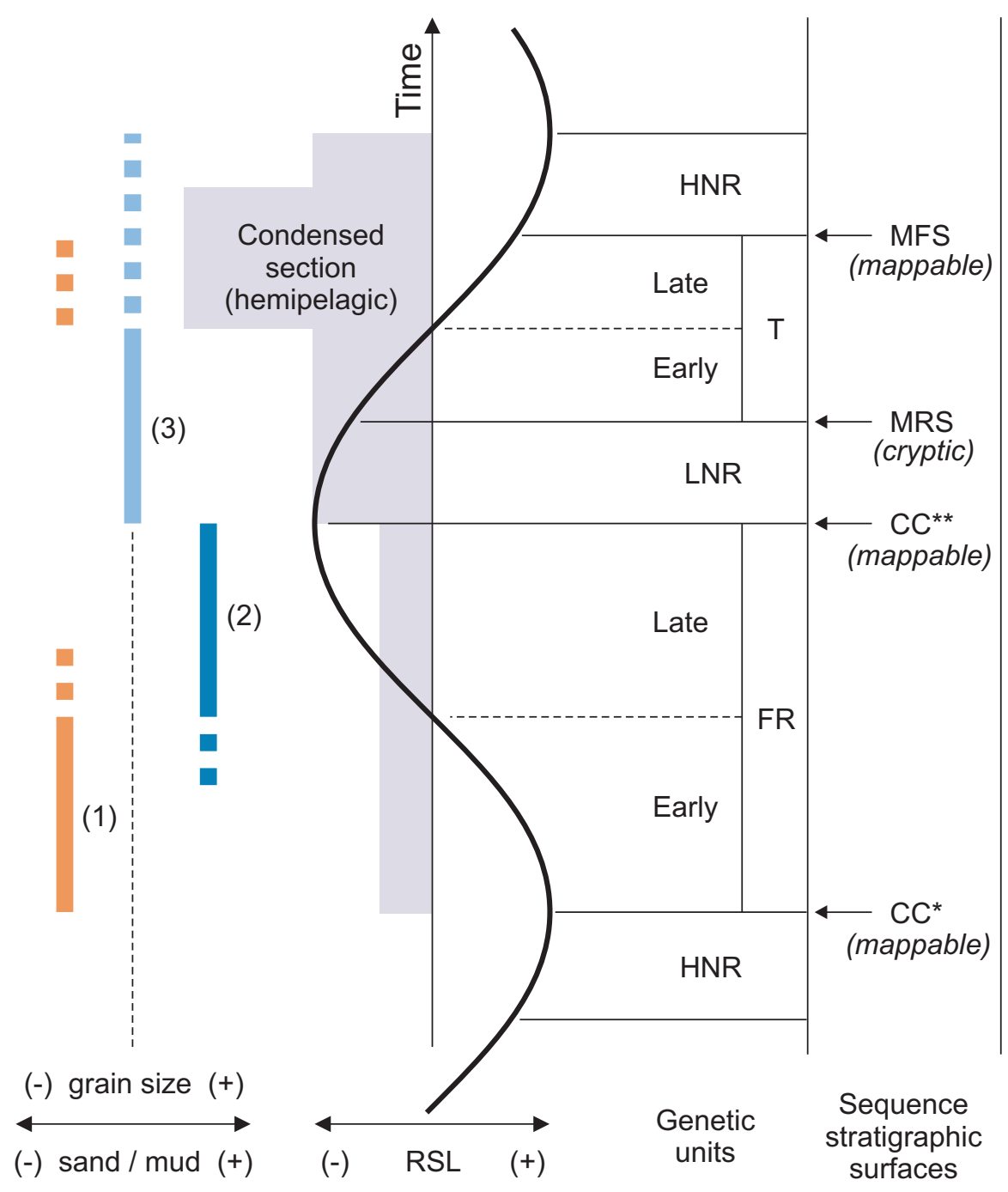

of relative fall, preventing the delivery of riverborne sediment beyond the shelf edge. As forced regression continues and coastlines prograde closer to the shelf edge, sand becomes available in the staging areas, giving rise to high-density turbidites during late stages of relative sea-level fall. The depositional elements of these high-density turbidites are dominated by extensive frontal splays on the basin floor, which may be connected to aggrading feeder channels on the continental slope. Besides episodic turbidity currents, catastrophic collapse of shelf-edge deltas during stages of late forced regression may also give rise to sandy debris flows that consist of large accumulations of massive sand.

\section{Lowstand normal regression}

The onset of relative sea-level rise marks a decrease in the volume, as well as the grain size, of the riverborne 


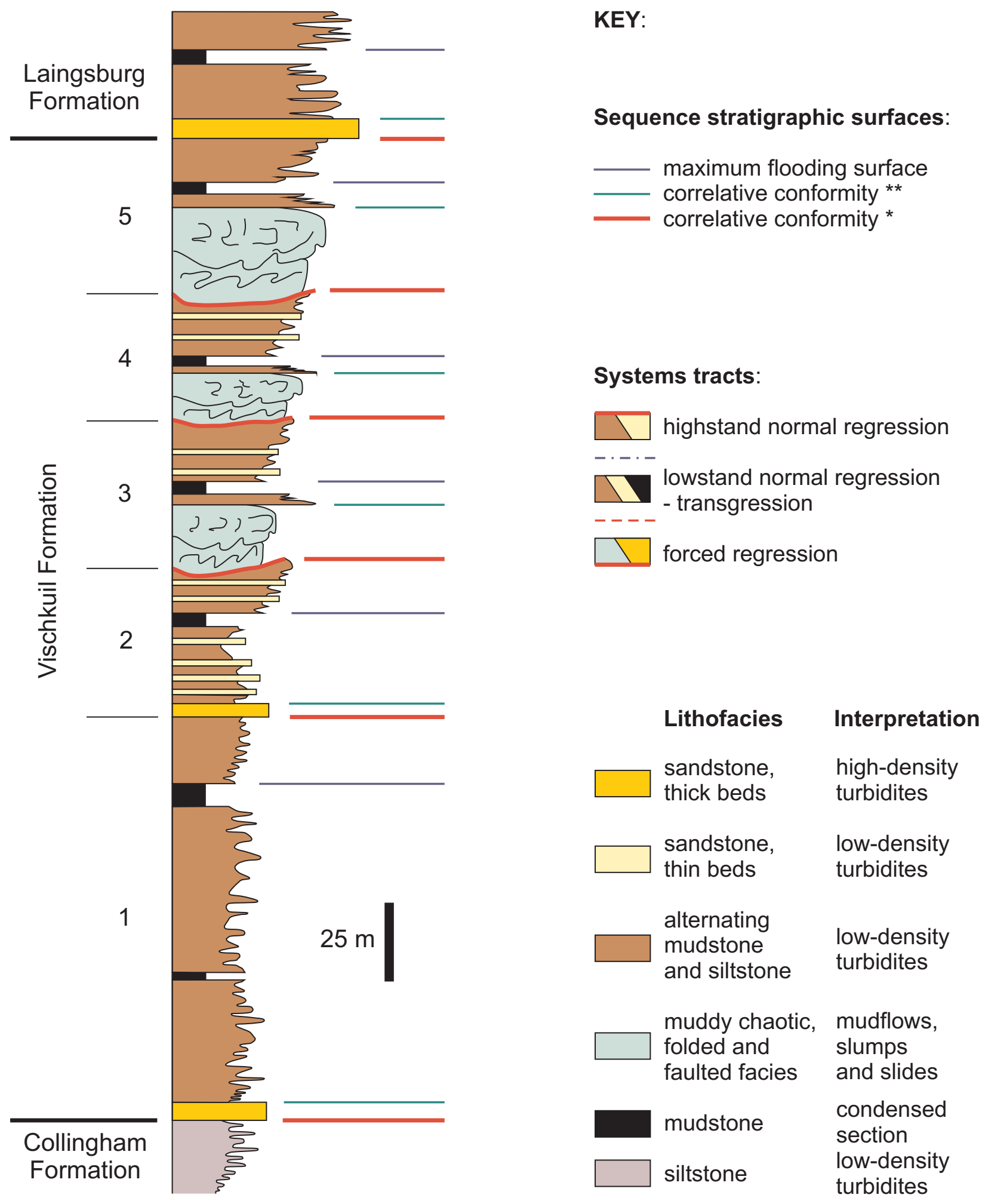

Fig. 31. Composite profile of the Vischkuil Formation, Karoo Basin, South Africa (modified from van der Merwe et al. 2010). 


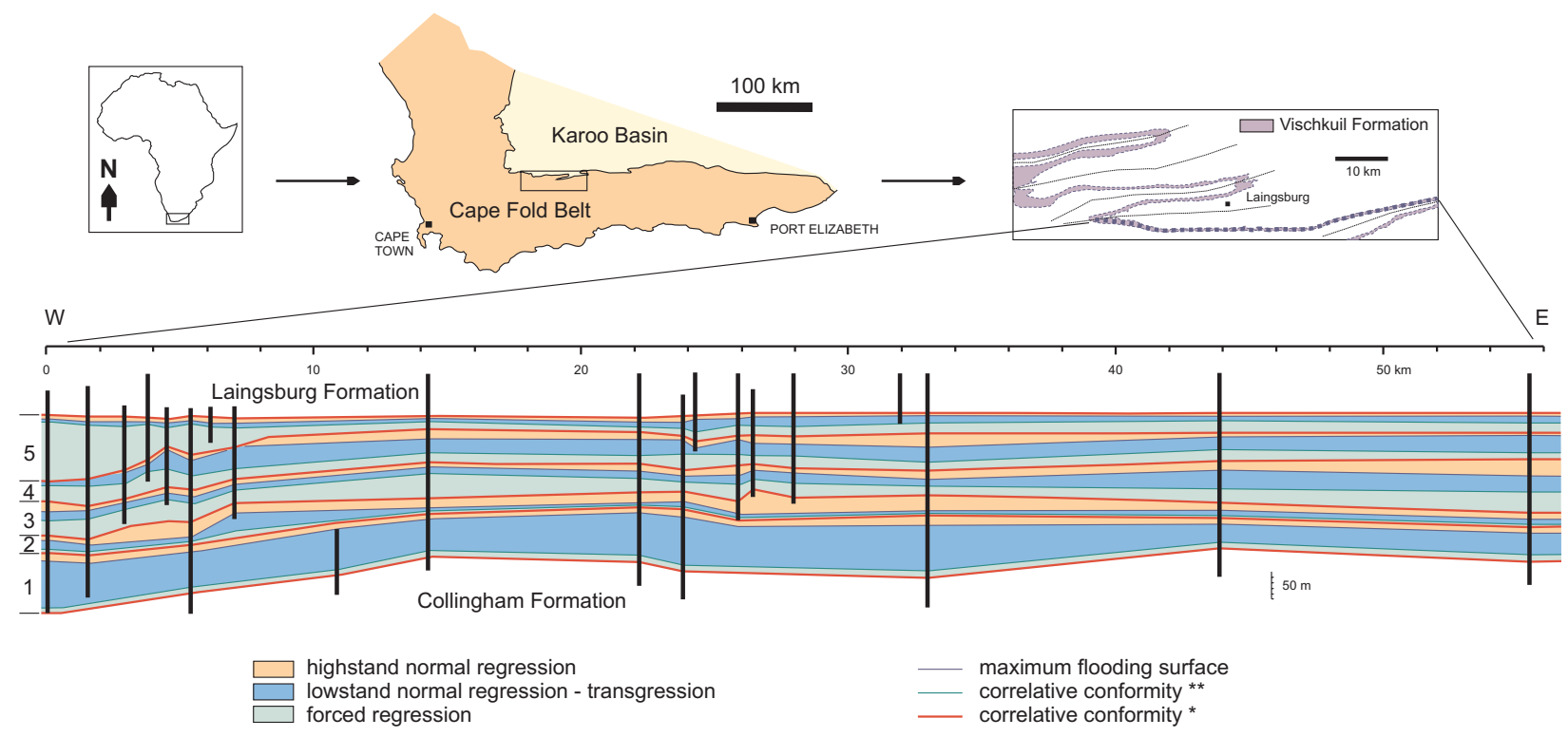

Fig. 32. Sequence stratigraphy of the Vischkuil Formation, Karoo Basin, South Africa (modified from van der Merwe et al. 2010). The Vischkuil Formation consists of five submarine fan complexes, corresponding to five depositional sequences (1-5), which include forced regressive, lowstand normal regressive, transgressive and highstand normal regressive systems tracts (see text for details). See Fig. 31 for a lithofacies description of the five sequences and component systems tracts. Vertical bars represent measured outcrop sections.

sediment delivered to the deep-water environment, as fluvial topsets trap the coarser sediment fractions on the shelf (Catuneanu 2006). As a result, the dominant type of gravity flow that carries sediment into the deep-water setting changes from the high-density turbidity currents of late forced regression to low-density turbidity flows characterized by lower sediment-towater and sand-to-mud ratios. The lower-density turbidites of the lowstand normal regression (i.e., the LST) are dominated by aggrading leveed-channel systems on the basin floor, which typically become entrenched updip on the continental slope (Posamentier and Kolla 2003).

\section{Transgression}

With the rapid creation of accommodation and concomitant trapping of riverborne sediment in backstepping fluvial and coastal systems, sediment entry points into the marine environment shift back from the shelf edge and the supply of sand to the deep water gradually decreases during transgression. The manifestation of low-density turbidity flows continues from the lowstand normal regression into early transgression, when coastlines are still close to the shelf-edge staging areas. However, these turbidity flows become progressively more diluted, finer grained and infrequent during transgression, to the point when sedimentation from suspension becomes the dominant process in the deepwater environment at the time of maximum flooding. In such cases, condensed sections characterize the late stages of transgression. Instability at the shelf edge during rapid increase in water depth, coupled with sediment starvation, may also result in upper slope failure and the manifestation of mass transport processes and mudflows during late transgression (Posamentier and Kolla 2003). The transgressive deposits form the TST.

\section{Highstand normal regression}

The highstand is a time of slow increase in accommodation, renewed progradation of coastlines following the maximum flooding, and relative stability at the shelf edge. In the case of wide continental shelves, riverborne sediment may also not reach the shelf edge. Consequently, gravity flows or mass transport processes are unlikely and infrequent in the deep-water environment, and condensed sections are typical for the deep-water portion of this (HST) systems tract. In the case of narrow continental shelves, coastal progradation may gradually bring the sediment entry points close enough to the shelf edge for the delivery of riverborne sediment into the deep-water environment (Porebski and Steel 2006; van der Merwe et al. 2010). In such cases, low-density turbidites may be recorded above the condensed section (Figs. 30, 31). 


\section{Case study: The Vischkuil Formation (Permian), Karoo Basin, South Africa}

The Ecca Group of the Karoo Supergroup includes depositional systems that exemplify both distal and proximal basin-floor settings, as well as overlying and prograding slope and shelf facies. The overall shallowing-upward succession from distal basin floor to shelf settings marks the transition from the underfilled to the filled phases in the evolution of the basin (Catuneanu et al. 2002). This case study presents the distal basin-floor succession of the Permian Vischkuil Formation in the Karoo Basin (Figs. 31, 32).

The Vischkuil Formation is a $280-380 \mathrm{~m}$ thick mudstone- and siltstone-dominated succession, which includes five sequences interpreted to have accumulated in relation to cyclic changes in accommodation on the shelf (van der Merwe et al. 2010; Figs. 31, 32). The bulk of the succession consists of gravity-flow and mass-transport deposits related to mudflows, slumps, high-density turbidity currents and/or grainflows, and low-density turbidity currents. Each cycle of sedimentation comprises a relatively thin (i. e., metre-scale) but regionally extensive condensed section of hemipelagic mudstone that represents a starved basin floor, likely corresponding to a stage of maximum flooding on the shelf (Figs. 30, 31). These condensed sections are markers for regional correlation, and help to delineate sequences.

Each condensed section is overlain by a succession of silty turbidites interpreted as an HST (Fig.31). Highstand systems tracts represent stages of renewed progradation and delivery of riverborne sediment into the deep basin, albeit in a relatively distal setting. The deposition is terminated by an abrupt shift in depositional regime marked by a sharp increase in sediment supply interpreted to mark the onset of relative sealevel fall, and hence the change from highstand normal regression to forced regression on the shelf. The boundary separating these two systems tracts is a surface of regional extent that is referred to as either the correlative conformity or the basal surface of forced regression.

The forced-regressive portions of sequences may include muddy chaotic facies associated with mudflows and slumps, as well as sandy facies related to high-density turbidity currents (Figs. 30, 31). The two older sequences include sandy deposits, whereas the overlying three sequences comprise muddy facies. This trend reflects the gradual progradation of the shelf edge through time.
The onset of lowstand normal regression is marked by a sharp decrease in sediment supply to the deepwater setting as sediment starts being trapped in aggrading fluvial topsets on the shelf. The boundary between forced regressive and lowstand normal regressive systems tracts is a type of correlative conformity (i.e., in the sense of Hunt and Tucker 1992). This surface can be traced regionally at the contact between forced regressive mudflow and/or high-density turbidity flow deposits and the overlying low-density turbidites that accumulate dominantly within leveedchannel systems (Figs. 30, 31, 32). The correlative conformity has lithological expression as it corresponds to an allogenic event that changes sediment supply to the basin within a short time interval (e.g., Fig. 11).

The lowstand low-density turbidity flows continued to dominate sedimentation during the transgressive stage as well, or at least during the early part of transgression (Posamentier and Kolla 2003; Catuneanu 2006). For this reason, the maximum regressive surface is cryptic in the deep-water system, within an undifferentiated succession of low-density turbidites. The turbidite succession of lowstand normal-regressive to transgressive deposits becomes finer through time, as progressively less frequent turbidity currents give way to dominantly condensed sections during late stages of transgression.

\section{Carbonate settings}

\section{Introduction}

A sequence stratigraphic framework applied to carbonates provides a major tool for the interpretation of the complex and diverse spectrum of the depositional systems, and the geometric architecture of their facies (Figs. 33, 34). The subdividing sequence stratigraphic surfaces identified in carbonates, just as with siliciclastic sediments, are erosional and flooding surfaces produced by base-level change (Handford and Loucks 1993). This framework of surfaces is regional in origin, and provides chronology to the order of deposition of the carbonate facies geometries defined by the hierarchy of the bounding surfaces and enables the interpretation and prediction of their extent and character. The methodology of this interpretive process is applicable no matter the response of the carbonates to the geotectonic setting and the physical, chemical and biological conditions of the specific depositional setting, 


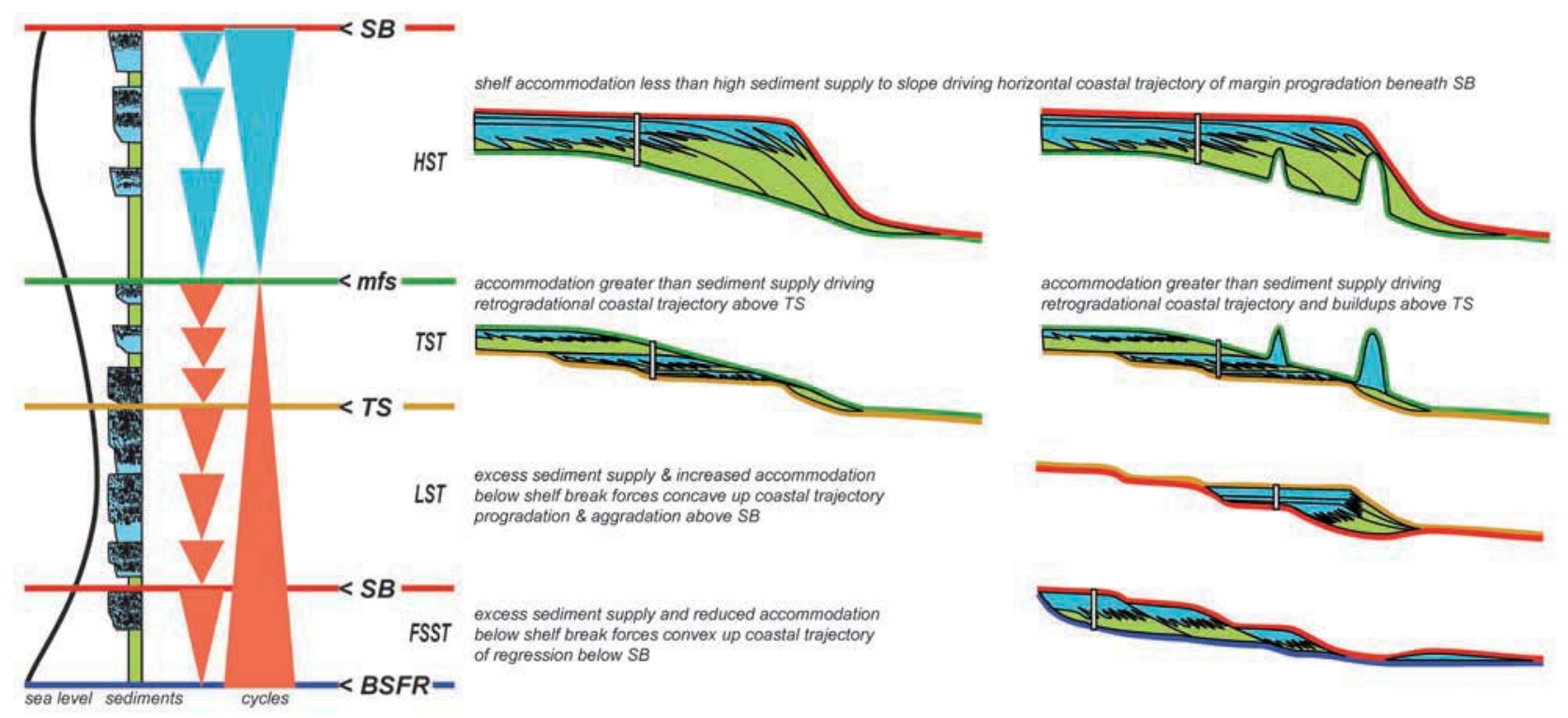

Fig. 33. Composite sequence stratigraphic framework of a carbonate platform with (right-hand side) and without (left-hand side) buildups. The lower portion of the diagram captures a carbonate margin where the falling-stage system tract (FSST) is expressed as a forced regression that progrades and downsteps seaward in response to the loss of accommodation as relative sea level falls. The three downstepping wedges of sediment build out over the basal surface of forced regression (BSFR) and terminate seaward in a basin-floor fan. Above the fan is a correlative conformity while up-dip the subaerial unconformity forming the sequence boundary (SB) overlies the downstepping sediment wedges of the forced regression. Over the unconformity is the lowstand systems tract (LST) expressed by a shoreline whose trajectory rises seaward. This is followed by three onlapping retrograding carbonate units of the transgressive systems tract (TST) that overlie a transgressive surface (TS) and are topped by a maximum flooding surface (MFS). This in turn is overlain by a highstand systems tract (HST) carbonate margin expressed as three shoaling-upward cycles which lie below the next depositional sequence boundary (SB). The designation of sequence boundary in this diagram conforms with Hunt and Tucker (1992). According to Posamentier and Allen (1999), the BSFR is the sequence boundary.

The vertical section on the left-hand side is a schematic column of the stacked sediments that accumulated within each systems tract. The approximate position of the sedimentary column is indicated by white strips on the sections; no one locality provides a complete section through all the systems tracts and parasequences; the FSST is represented by a section that is basinward; the LST has a section even farther basinward, and the section for the TST and HST parasequences is better expressed further onto the platform.

be it a basin with a steep margin, a homoclinal ramp or an epeiric sea (Figs. 35, 36).

Though carbonate depositional settings and their associated sediments have some similarities to clastics, major differences exist. Clastics are transported to their depositional setting, while carbonate sediments are the products of in situ generation linked to carbonate-producing organisms, many of which are products of depth-dependent photosynthetic activity and so have their greatest rates of generation close to the air/sea interface of the depositional setting. The depth-dependent character of most carbonate facies (with the exception of mass transport down slope) means they are often tied directly to sea-level position whereas clastics are not. This often causes the character of carbonate sediment to change predictably during lowstands, rap- id transgression, and/or highstands of sea level, whereas clastics do not provide such clear indicators of sealevel position. Additionally carbonate sediments normally have a biochemical origin and so are influenced by the chemistry of the water from which they precipitated. This means that carbonate facies can also be used to determine changes in paleogeography, including the development of isolation or access to the open sea (Fig. 37) providing a better understanding of their depositional setting and relationship to plate-tectonic configuration, and changes in paleoclimate. In addition the evolution of the organisms, whose skeletal remains form many carbonates, can provide better time controls on the sedimentary succession. Thus carbonates, as indicators of depositional setting, when combined with the sequence stratigraphic framework often form more 

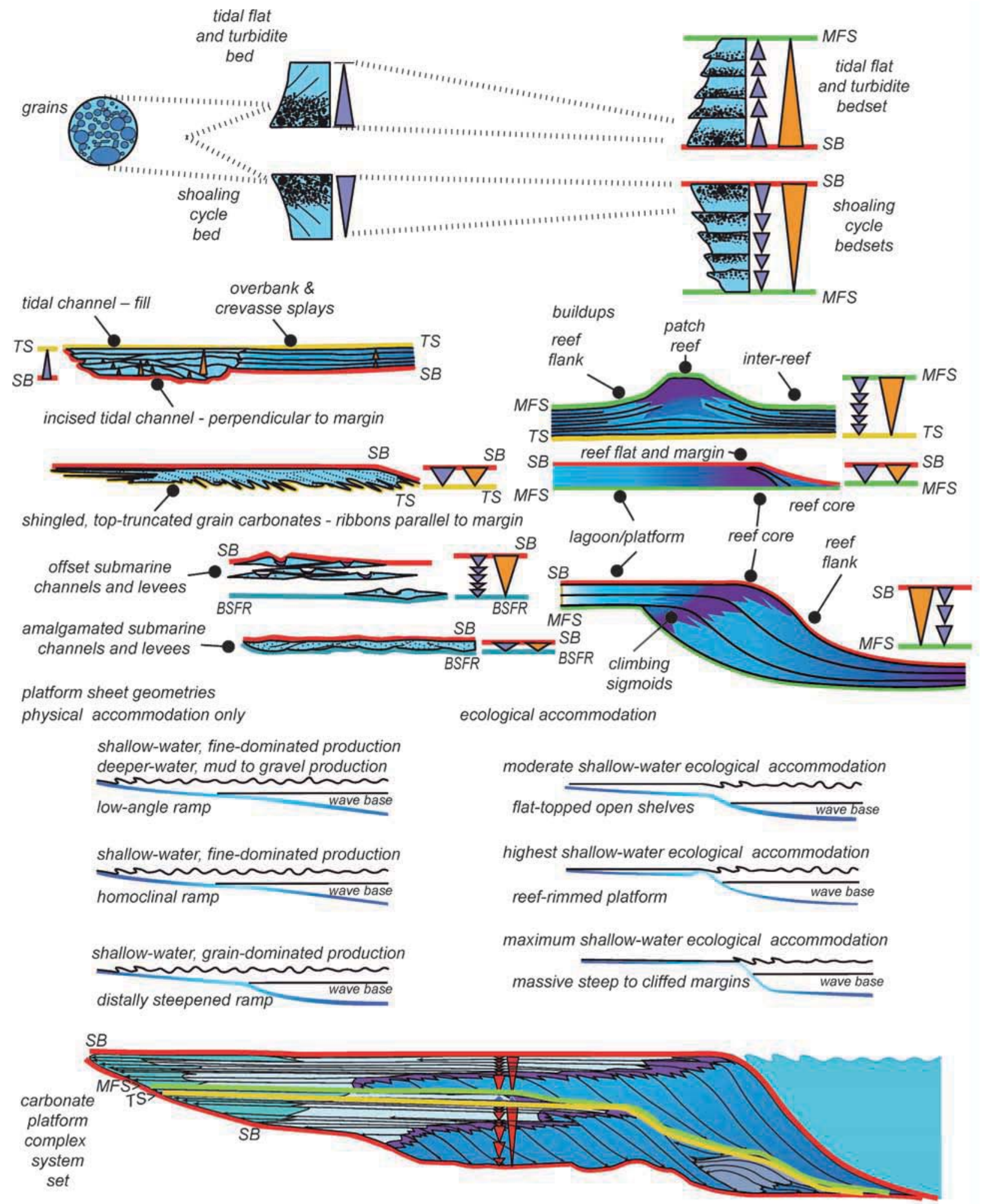

Fig. 34. Hierarchy of carbonate architectural elements from carbonate grains to cycles, bedsets, incised tidal channel fill (single units to complexes that extend perpendicular to the basin margin), shingled carbonate ribbons (complexes of intertidal beaches and or shoals that parallel the basin margin), build-ups (patch reef), reef flat, climbing sigmoids, offset submarine channels and levees, amalgamated submarine channels and levees, platform sheet geometries in response physical and ecological accommodation, and carbonate platform complex system set. Note relationship to depositional sequence boundaries, transgressive surfaces (TS) and maximum flooding surfaces (MFS). 
biological factors
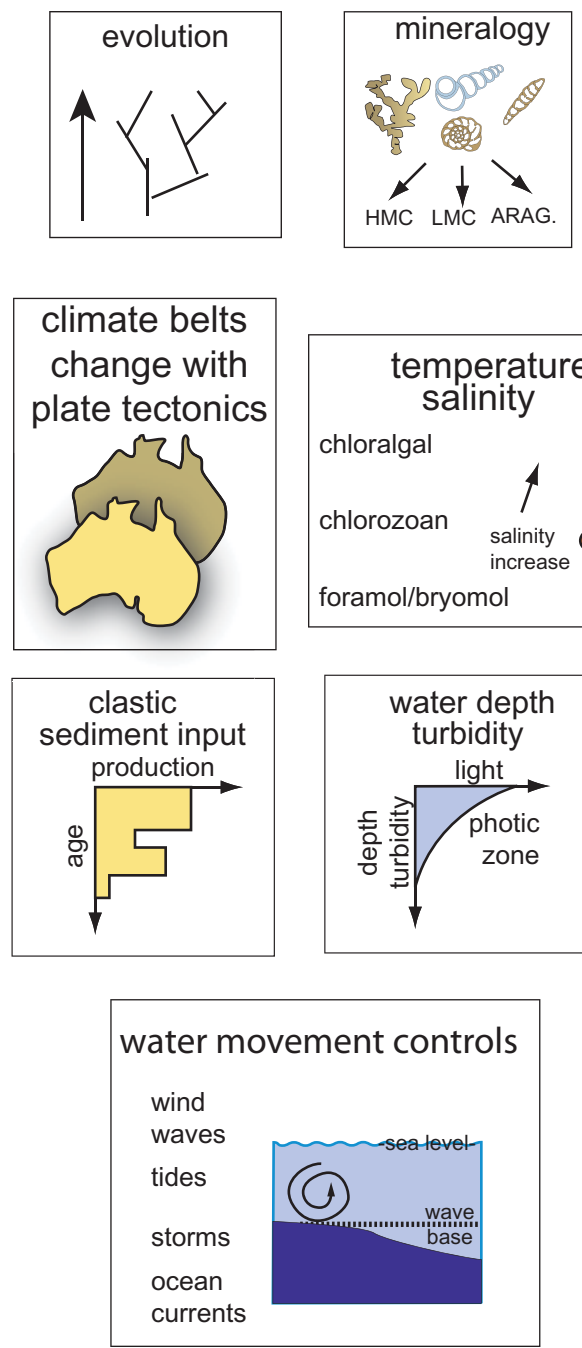
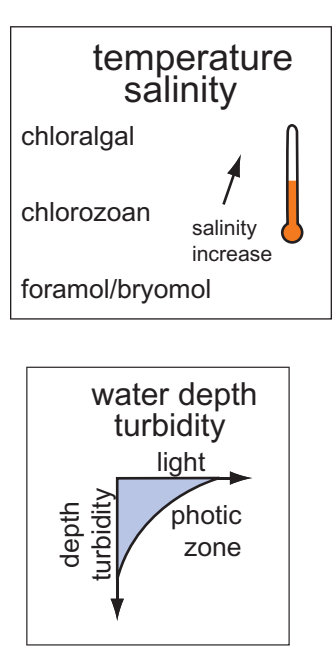

\section{controls on carbonate accumulation}

controls on accommodation

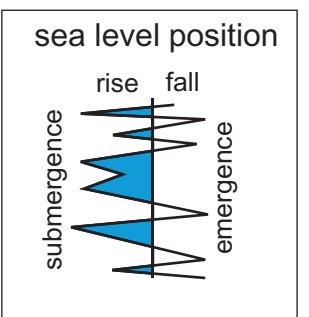

subsidence

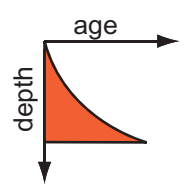

accumulation

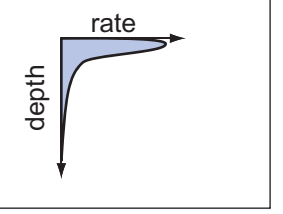

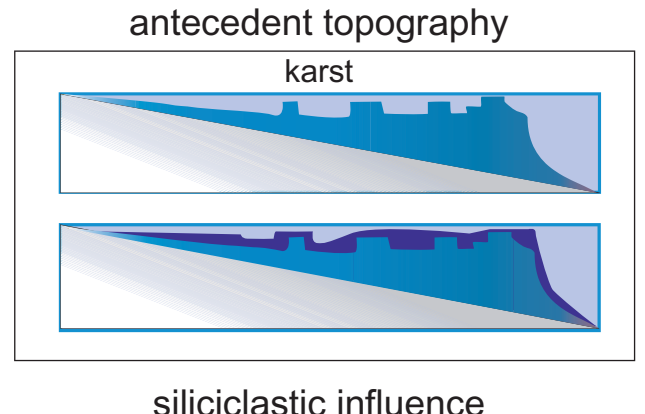

siliciclastic influence

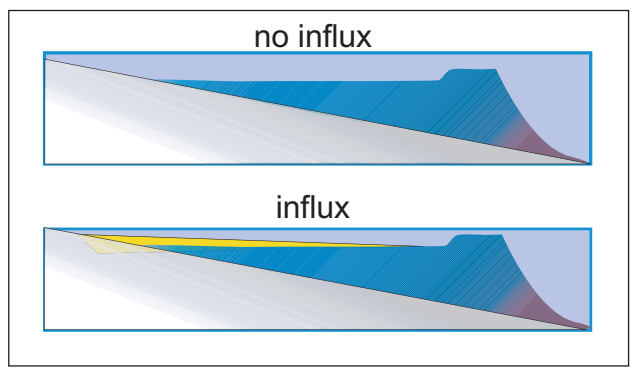

platform morphology

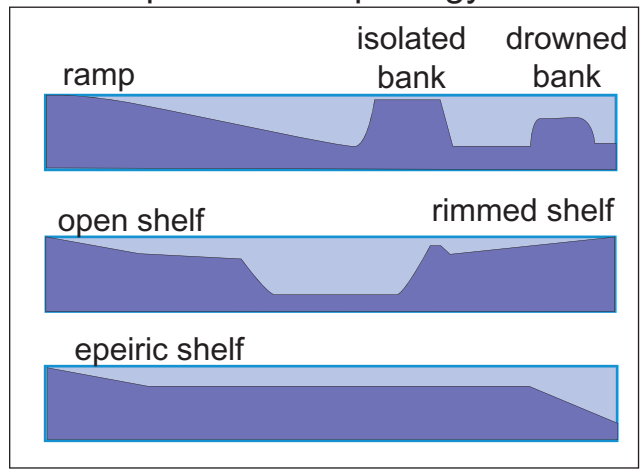

Fig. 35. Main factors that control the formation of carbonate successions on platforms (after Jones and Desrochers 1992).

powerful interpretive indicators than clastics. Carbonates can therefore enhance the prediction of both the lithofacies and the hierarchies that develop within this framework away from data-rich areas.

\section{Framework of carbonate sequence stratigraphic geometries}

The hierarchy of carbonate sequence stratigraphic geometries includes those associated with normal and forced regressions of highstand, falling stage and lowstand systems tracts; and onlapping retrogradation transgressive geometries (Figs. 33, 38-40). As with clastics, the geometries of carbonate strata are products of the morphology of the depositional surface, and rates of change of base level and sediment accumulation. For instance when rates of change are rapid, as on Figures 4 and 33, during lowstand normal regression it is not uncommon for carbonates to prograde through time while rates of aggradation increase with a resulting coastal trajectory that is concave upwards; conversely with highstand normal regressions it is not uncommon that progradation increases with time while aggradation decreases, leading to a coastal trajectory that is convex up. During forced regressions, downstepping occurs. As with clastics too, these geometries are defined by the bounding surfaces that include those formed during and following transgressions (TS and MFS) and those that formed during falls in sea level as regressive surfaces (SBs). Physical erosion, burrowing, boring, dissolution (Clari et al. 1995; Lukasik and 


\section{Carbonate response to sea-level rise}
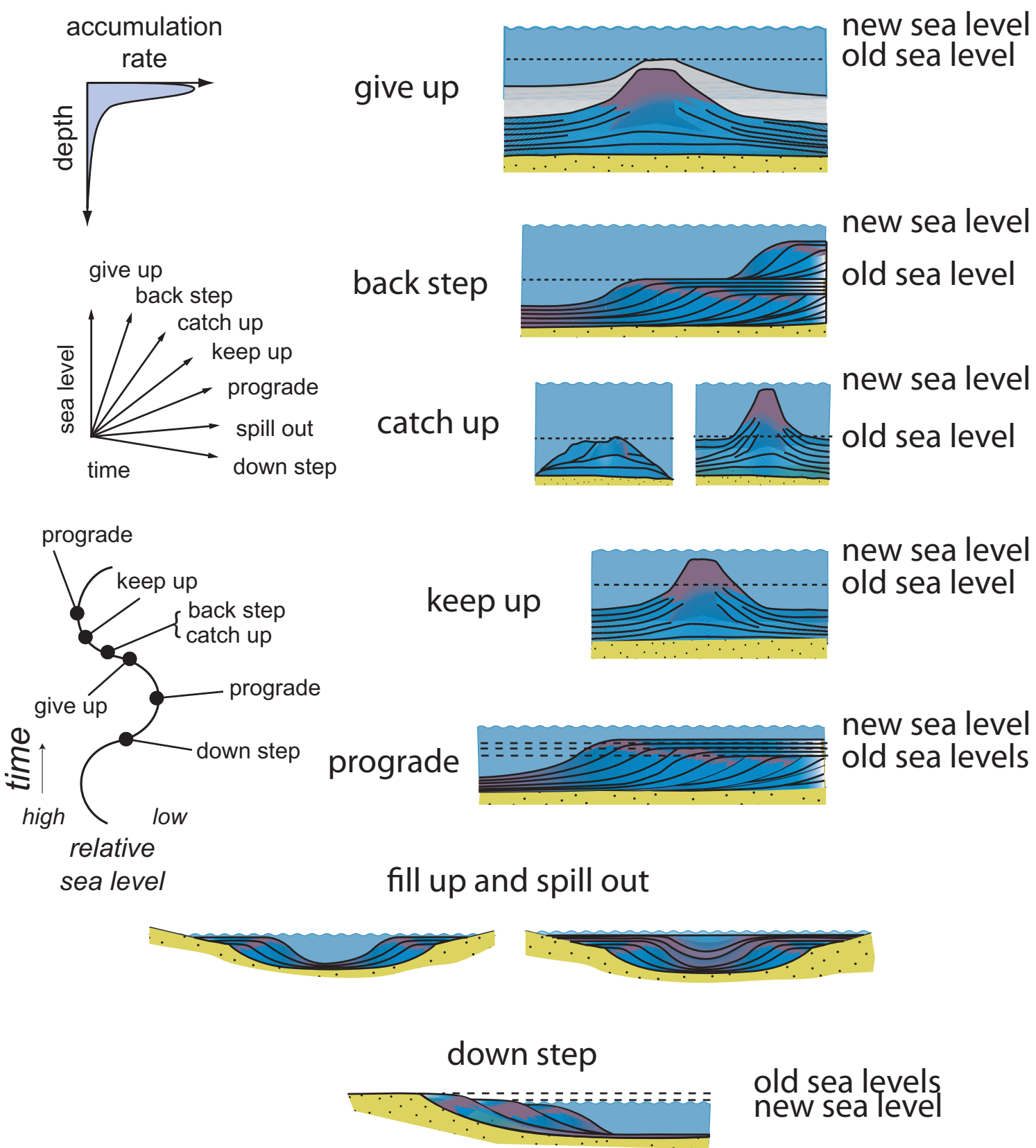

Fig. 36. The carbonate response to relative sea-level change (after Scaturo et al. 1989).

James 2003), and/or cementation may have modified these surfaces. Whatever their origin, these surfaces mark changes in the depositional regime, particularly base level, and provide a convenient means to subdivide the carbonate section. From the perspective of sequence stratigraphy, these surfaces are used to determine the order in which strata are laid down and to define the geometries that they enclose, and so interpret their depositional setting. Biostratigraphic data (both skeletal remains and ichnology) when tied to the stratal units, enable the direct comparison between shallowmarine and deeper-marine carbonate sequences, their related units and the potential correlation of the carbonate cycles to relative sea-level rise and fall.

Carbonate strata can be expressed (Fig. 34) as unconfined sheets, unconfined but localized buildups 
(reefs, banks and islands), unconfined but localized sigmoids (reef cores; Pomar 1991) and bank margins, and confined incised channels (tidal channels and the product of flood events). Just as with clastics, whatever the final carbonate geometry formed, this geometry is the product of both accumulation (aggradation, retrogradation and progradation) and erosion.

As with clastics, sequence stratigraphy of carbonate successions is commonly determined from a combination of the comparatively low-frequency resolution of 2D and 3D seismic data, the high-frequency resolution of well $\operatorname{logs}$, the very high-frequency resolution of cores and a combination of high-frequency resolution and low-frequency resolution from outcrops. However, unlike clastics, marine carbonate successions are the products of base-level change that generates accommodation expressed in two forms (Pomar and Kendall 2008) (Fig.34): physical accommodation (controlled by hydrodynamic conditions) and ecologi- cal accommodation (controlled by organisms and their productivity).

\section{Carbonate sequence stratigraphy and depositional setting}

A carbonate sequence stratigraphic framework provides a useful explanation of carbonate depositional setting and predictions of potential carbonate plays and reservoir models. It links depositional settings, facies, geometries, fauna, and systems tracts (see Figs. 38-40 and Table 1).

In conclusion, a sequence stratigraphic framework for carbonate rocks can be used to predict the extent and character of facies geometries, whether these carbonate sediments accumulated in updip platforms, platform margins, margin slopes and/or downslope basins. The literature is replete with examples of the effective use of sequence stratigraphic methodology including many on the Permian Basin of west Texas

\section{Relationship of UAE Holocene carbonate grains to hydrodynamic setting}

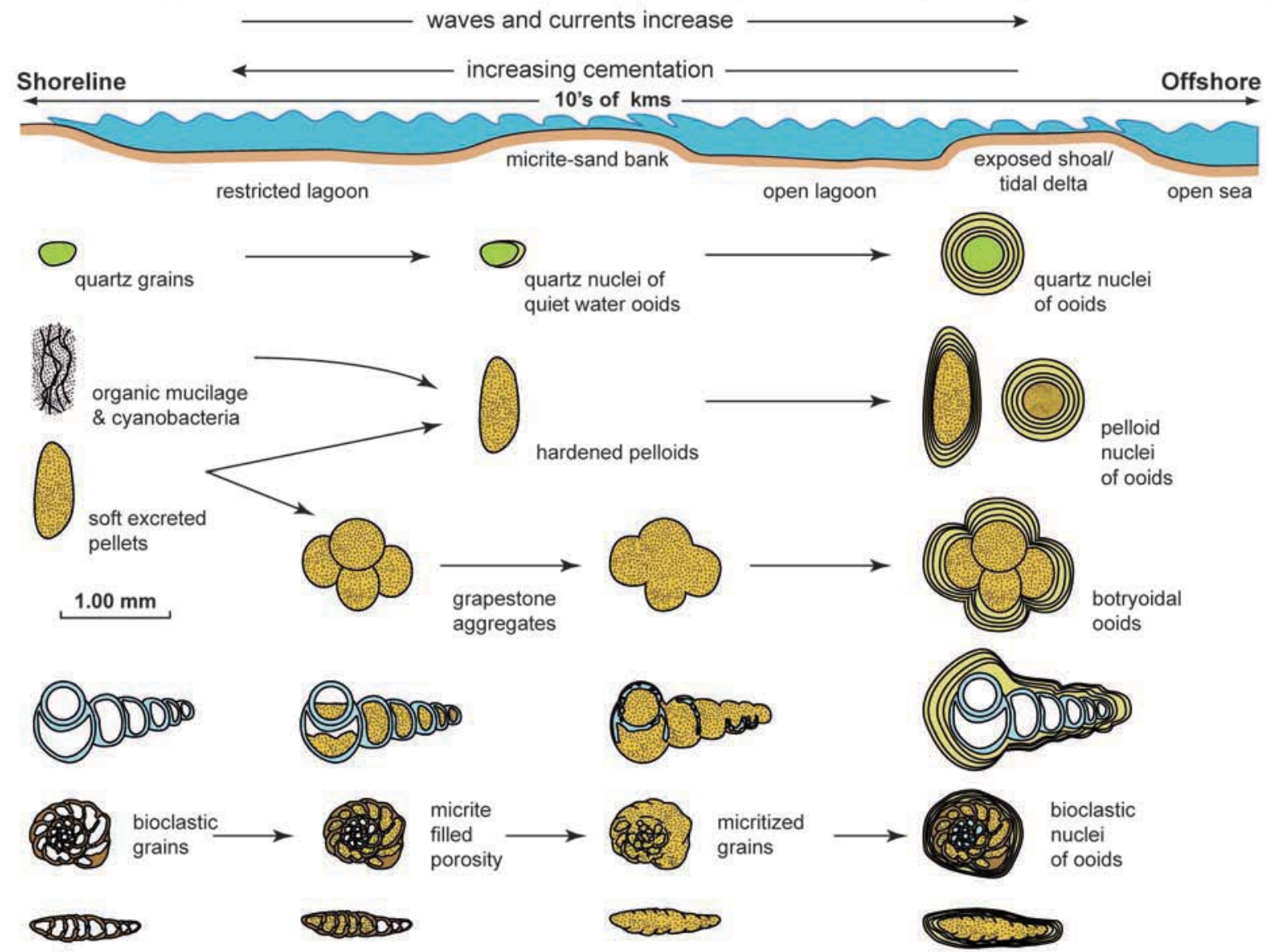

Fig. 37. Relationship of carbonate grains to cementation, and waves and currents, based on the Holocene carbonate ramp of the United Arab Emirates and analogous to epeiric sea settings too. 
carbonate shoreline, shelf and marginal settings

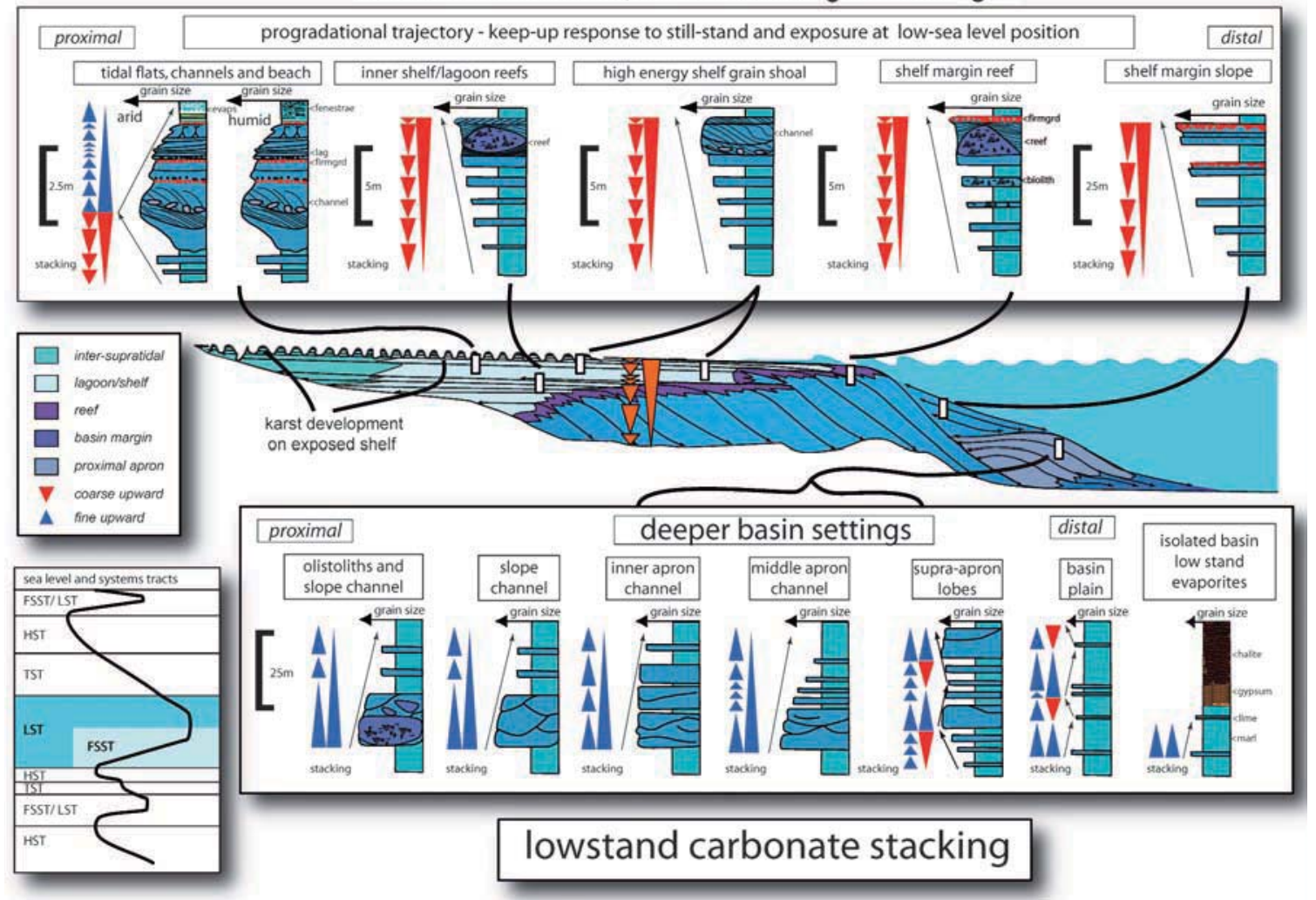

Fig. 38. Lowstand carbonate stacking including progradational trajectory and keep up response to stillstand of relative sea level at a low sea level position within the basin and the downslope deeper basinal settings.

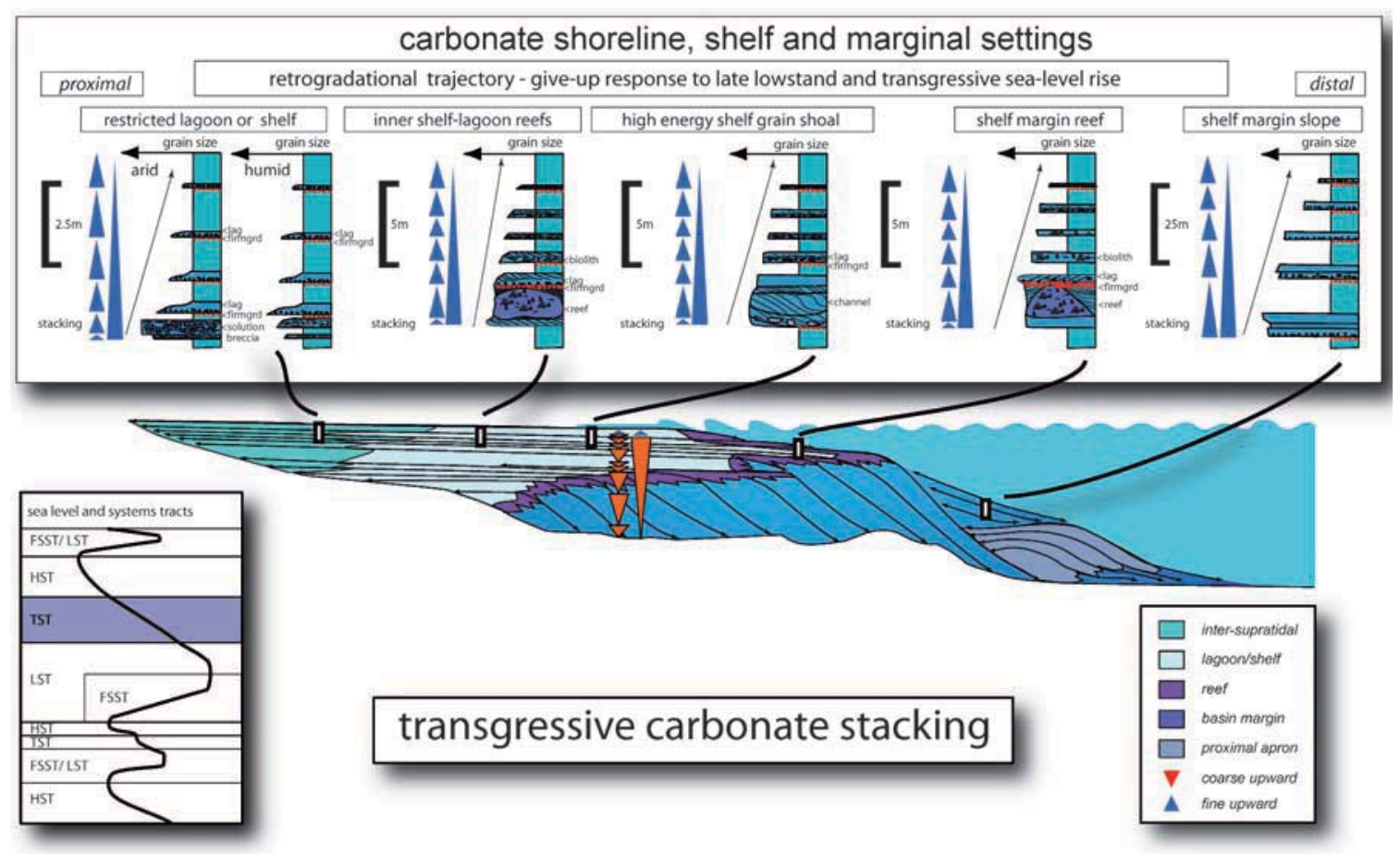

Fig. 39. Transgressive carbonate stacking including retrogradational trajectory and keep-up response to rapid rising of relative sea level during a transgression across a carbonate shelf. 


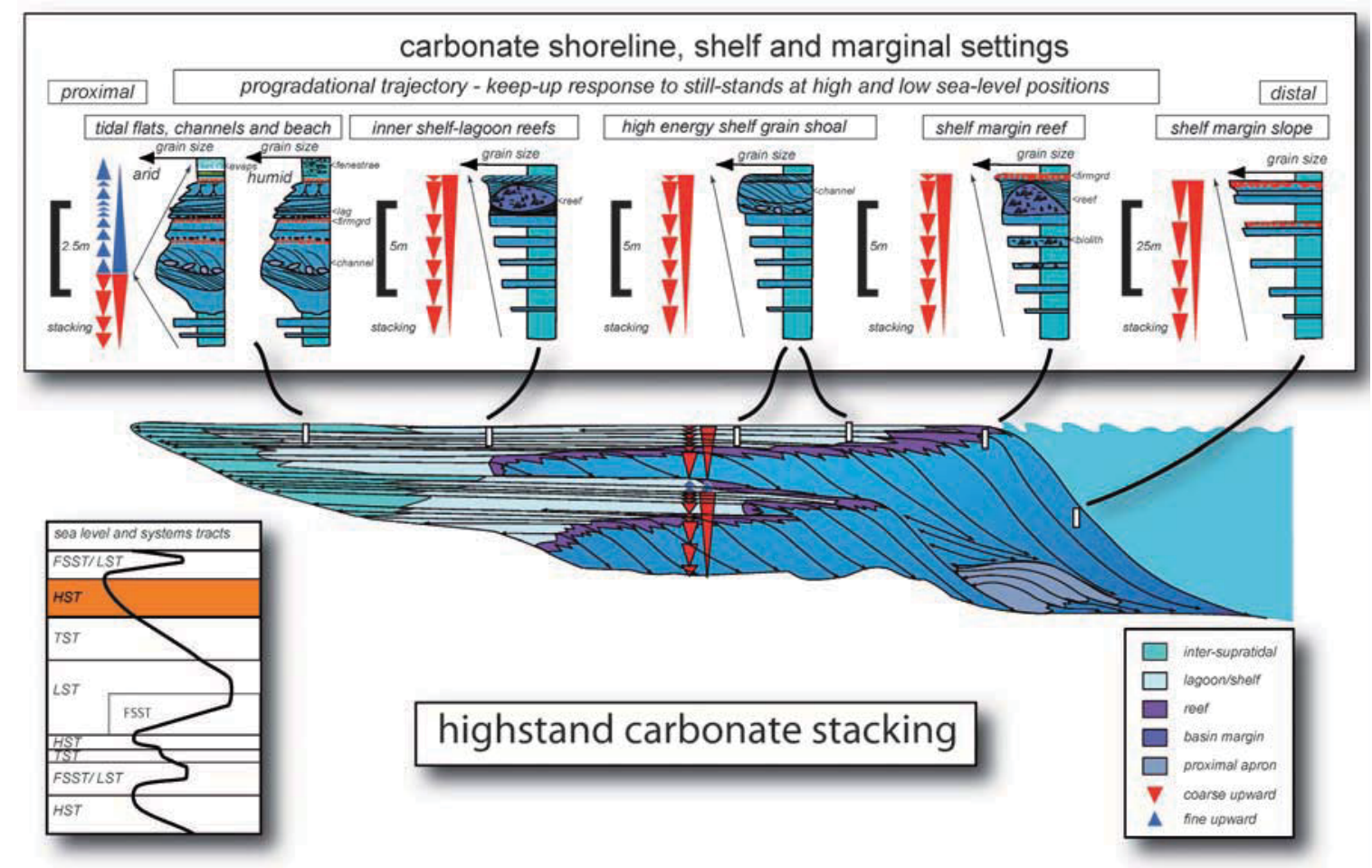

Fig. 40. Highstand carbonate stacking including progradational trajectory and keep-up response to stillstand of relative sea level at a high sea level position.

and New Mexico (Tinker 1998; French and Kerans 2004); Carboniferous of the Sacramento Basin (Bachtel and Dorobek 1994; Bachtel et al. 2000a, b); Cretaceous carbonate platforms of central Texas (Kerans et al. 1997a, b; Kerans 2002); Mississippian Paradox Basin carbonates (Eberli et al. 2005; Grammer and Ritter 2008); Mississippian Mission Canyon Formation (Read and Dorobek 1993; and Smith et al. 2003); Mesozoic of the Middle East (Sharland et al. 2001; van Buchem et al. 2002, 2003); Miocene carbonates of the Balearic Islands (Pomar 1993; Pomar and Ward 1995, 1999); the platform to basin transition of the Maiella platform, Italy (Eberli et al. 2004); and Cretaceous (Aptian) of the Maestrat Basin, eastern Spain (BoverArnal et al. 2009).

\section{Case study: Late Jurassic (Kimmeridgian) platform-to-basin correlation, Jura Mountains}

In the Swiss and French Jura Mountains, the massive carbonate beds of the Kimmeridgian form prominent cliffs in the landscape. These carbonates originated in the shallow, subtropical waters of the platform that separated the Vocontian Basin (a branch of the Tethys ocean) to the south from the Paris Basin to the north (Dercourt et al. 2000). Detailed sections have been logged and high-resolution sequence- and cyclostratigraphic interpretations have been performed by $\mathrm{Co}-$ lombié (2002), Colombié and Strasser (2005), and Colombié and Rameil (2006). Ammonites in these platform sediments are rare but nevertheless they do furnish a biostratigraphic framework (Gygi 2000). A more refined ammonite biostratigraphy has been established in time-equivalent hemipelagic sections in the Vocontian Basin (Atrops 1982). Consequently, the platformto-basin correlation allows the placing of recognized sequence-stratigraphic elements into a biostratigraphic framework. This further permits a comparison of the studied interval with the sequence-chronostratigraphic chart that Hardenbol et al. (1998) prepared for the European basins. For the present case study, five outcrop sections are presented, focusing on the interval covering the Ataxioceras hypselocyclum and Crussoliceras divisum ammonite biozones (Figs. 41, 42).

In the platform sections, a prominent break in vertical facies evolution occurs where birdseyes indicate that lagoonal lime mudstones shallowed up into a tidal flat (Court) and where birdseyes, charophytes, and dolomitization suggest intertidal to supratidal condi- 
Table 1 Carbonate sequence stratigraphy and depositional setting. Carbonate sequence stratigraphy links depositional settings and fauna to a predictable framework of facies, geometries, systems tracts and bounding surfaces. The facies, geometries, fauna and the framework of systems tracts recorded by epeiric seas are similar to those of shelf settings.

\begin{tabular}{|c|c|c|c|c|c|}
\hline Setting & Inner Shelf & Outer Shelf & Margin & Slope & Basin \\
\hline Facies & $\begin{array}{l}\text { Sediment homogeneous - } \\
\text { Micrites, peloids to } \\
\text { bioclastic packstone to } \\
\text { wackestone; local evapor- } \\
\text { ites } \\
\text { Shallowing upward cycles } \\
\text { common, predictable and } \\
\text { correlatable finer carbon- } \\
\text { ate capped by tidal-flat } \\
\text { dominated by cyanobacte- } \\
\text { ria and/or evaporites }\end{array}$ & $\begin{array}{l}\text { Sediment heterogeneous: } \\
\text { ooids, grapestones and } \\
\text { hardened peloids to } \\
\text { bioclastic grain shoals to } \\
\text { patch reef and shoal build } \\
\text { ups } \\
\text { Shallowing upward cycles } \\
\text { common, predictable and } \\
\text { correlatable }\end{array}$ & $\begin{array}{l}\text { Sediments heterogeneous } \\
\text { to homogenous, reefal } \\
\text { boundstones, bioclastic } \\
\text { packstone to grainstone } \\
\text { accumulations } \\
\text { Shallowing upward cycles } \\
\text { common }\end{array}$ & $\begin{array}{l}\text { Upslope: Heterogeneous } \\
\text { wackestones to packstones } \\
\text { to grainstone and rudstone } \\
\text { offbank transport } \\
\text { Lime mudstone-wacke- } \\
\text { stone from fine-grained } \\
\text { periplatform shedding and } \\
\text { quiescent foreslope } \\
\text { Local presence of well- } \\
\text { sorted grain-rich tem- } \\
\text { pestites } \\
\text { Brittle reef failure and de- } \\
\text { bris of breccias and blocks } \\
\text { (olistoliths) common } \\
\text { Down slope homogenous } \\
\text { dispersed bioclastic pack- } \\
\text { stone to mudstone from } \\
\text { upslope, often bioturbated } \\
\text { Fining-upward cycles } \\
\text { common }\end{array}$ & $\begin{array}{l}\text { Homogenous cycles of mud- } \\
\text { stone, marl to shale, from } \\
\text { relative sea-level changes } \\
\text { Fining-upward cycles } \\
\text { common }\end{array}$ \\
\hline Geometry & $\begin{array}{l}\text { Unconfined sheets of } \\
\text { homogeneous sediment } \\
\text { Local storm-driven } \\
\text { confined channel fills }\end{array}$ & $\begin{array}{l}\text { Unconfined heterogeneous } \\
\text { sediment sheets } \\
\text { Local confined channel } \\
\text { fills } \\
\text { Local confined lens- } \\
\text { shaped buildups }\end{array}$ & $\begin{array}{l}\text { Unconfined thick to mas- } \\
\text { sive homogeneous sheets } \\
\text { to linear bodies parallel } \\
\text { (barrier shoals) or perpen- } \\
\text { dicular (tidal channels) to } \\
\text { margin }\end{array}$ & $\begin{array}{l}\text { Interfingering unconfined } \\
\text { aggraded and retrograded } \\
\text { foreslope clinoform sheets; } \\
\text { thicken upslope/thin } \\
\text { downslope } \\
\text { Local confined sheets and } \\
\text { channel fill can be com- } \\
\text { mon }\end{array}$ & $\begin{array}{l}\text { Unconfined thin widespread } \\
\text { sheets }\end{array}$ \\
\hline Fauna & $\begin{array}{l}\text { Fauna often high numbers } \\
\text { and restricted }\end{array}$ & $\begin{array}{l}\text { Fauna commonly shallow } \\
\text { water, heterogeneous and } \\
\text { moderately cosmopolitan }\end{array}$ & $\begin{array}{l}\text { Fauna high numbers and } \\
\text { cosmopolitan } \\
\text { Downslope ecological } \\
\text { accommodation common } \\
\text { with massive boundstones } \\
\text { and heterogeneous open- } \\
\text { marine 'reef-building' } \\
\text { skeletal materials often } \\
\text { grain-prone in distal por- } \\
\text { tions; upper bounding } \\
\text { surfaces often SB and less } \\
\text { visible MFS }\end{array}$ & $\begin{array}{l}\text { Fauna high numbers } \\
\text { upslope but sparser and } \\
\text { restricted downslope } \\
\text { Bioturbation cosmopolitan } \\
\text { in shallows protected from } \\
\text { heavy wave action; } \\
\text { in deeper upper slope } \\
\text { burrowing often intense }\end{array}$ & $\begin{array}{l}\text { Fauna low numbers and } \\
\text { sparse away from margin } \\
\text { Bioturbation common on } \\
\text { surfaces with low supply } \\
\text { rates }\end{array}$ \\
\hline $\begin{array}{l}\text { LST } \\
\text { (Fig. 41) }\end{array}$ & $\begin{array}{l}\text { FSST and subsequent LST } \\
\text { exposure SBs, potential } \\
\text { karstification and/or no } \\
\text { accumulation }\end{array}$ & $\begin{array}{l}\text { FSST and LST common } \\
\text { exposure surfaces and dis- } \\
\text { continuous mudstone to } \\
\text { wackestone fill of incised } \\
\text { tidal channels perpendicu- } \\
\text { lar to margin overlain by } \\
\text { discontinuous to continu- } \\
\text { ous microbial flat sheets }\end{array}$ & $\begin{array}{l}\text { FSST and LST include ex- } \\
\text { posure surfaces, or, where } \\
\text { sea-level fall less, forced } \\
\text { regressions of packstone } \\
\text { and wackestone facies of } \\
\text { shoreline bodies of upper } \\
\text { slope area (perched } \\
\text { parasequences) parallel to } \\
\text { margin }\end{array}$ & $\begin{array}{l}\text { FSST and lowstand LST } \\
\text { erosional surfaces from } \\
\text { sediment bypass from } \\
\text { upslope, downslope from } \\
\text { forced regressive shore- } \\
\text { lines with wackestone and } \\
\text { packstone facies extending } \\
\text { downslope from the basin } \\
\text { margin } \\
\text { FSST/LST collapse } \\
\text { margin megabreccias at } \\
\text { sea-level falls }\end{array}$ & $\begin{array}{l}\text { LST and TST (and early } \\
\text { HST) when platforms ag- } \\
\text { grade rapidly they, and slope, } \\
\text { supply debris and mud flows }\end{array}$ \\
\hline $\begin{array}{l}\text { TST } \\
\text { (Fig. 42) }\end{array}$ & $\begin{array}{l}\text { TST often missing or } \\
\text { reworked earlier sediments }\end{array}$ & $\begin{array}{l}\text { TST onlapping linear } \\
\text { sheets parallel to margin } \\
\text { with local aggradation of } \\
\text { TST lenses }\end{array}$ & $\begin{array}{l}\text { TST onlapping sheets of } \\
\text { open-marine facies of } \\
\text { mudstones, wackestones } \\
\text { and packstone sheets }\end{array}$ & $\begin{array}{l}\text { TST onlapping sheets of } \\
\text { open-marine facies of } \\
\text { argillaceous lime mud- } \\
\text { stone and wackestone; } \\
\text { local buildups, especially } \\
\text { over topographic highs }\end{array}$ & $\begin{array}{l}\text { LST and TST (and early } \\
\text { HST) when platforms ag- } \\
\text { grade rapidly they, and slope, } \\
\text { supply debris and mud flows }\end{array}$ \\
\hline $\begin{array}{l}\text { HST } \\
\text { (Fig. 43) }\end{array}$ & $\begin{array}{l}\text { HST base of organic-rich } \\
\text { argillaceous carbonate or } \\
\text { shale }\end{array}$ & $\begin{array}{l}\text { HST elevated aggradation- } \\
\text { al, linear, ribbons of lime- } \\
\text { sand barriers and shoals } \\
\text { parallel to margin capped } \\
\text { by subaerial SBs }\end{array}$ & $\begin{array}{l}\text { HST base of finer lime } \\
\text { mudstones and wacke- } \\
\text { stones, and overlain by } \\
\text { aggrading shallowing-up } \\
\text { cycles of grainstone rib- } \\
\text { bons parallel to the plat- } \\
\text { form margin and massive } \\
\text { merging boundstone paral- } \\
\text { lel to margin capped by } \\
\text { subaerial SB }\end{array}$ & $\begin{array}{l}\text { HST lime mudstone to } \\
\text { wackestone sheets from } \\
\text { margin, SB erosional to } \\
\text { subaerial unconformity } \\
\text { caps }\end{array}$ & $\begin{array}{l}\text { HST platform shedding, } \\
\text { grain-flow, density-flow } \\
\text { and turbidite sands and less } \\
\text { lime mud. Lower slope } \\
\text { thinning-thickening upward } \\
\text { calciturbidites metre-scale } \\
\text { and upwards beds, product of } \\
\text { millennial eustatic or climatic } \\
\text { change }\end{array}$ \\
\hline
\end{tabular}


tions with local freshwater lakes (Péry-Reuchenette; Fig. 41). At Pichoux, black pebbles and a restricted-lagoonal mudstone point to very shallow conditions. In the basin, at Châteauneuf-d'Oze, a slump in the Ataxioceras hippolytense subzone implies slope instability. At Crussol, thick limestone beds suggest low sea level that forced export of carbonate mud from the platform (Colombié and Strasser 2003). Hardenbol et al. (1998) placed a sequence boundary 'Kim2' at the base of the A.hippolytense subzone. It is therefore suggested that the observed features (indicating a fall in relative sea level) correspond to this sequence boundary.

Facies in the platform sections occur in beds and bedsets that can be interpreted as small-scale depositional sequences (Strasser et al. 1999). While the individual beds do not necessarily display a facies evolution indicating a relative sea-level fluctuation, the bedsets can in several cases be interpreted in terms of sequence stratigraphy: they commonly have an erosive base, display a deepening-up part composed of lagoonal packstones to grainstones with reworked material, and have a maximum-flooding to early highstand part with low-energy wacke- to mudstones. Towards the top of these sequences, higher energy deposits indicate shallowing towards the following bounding surface (e.g., small-scale sequences 3 and 4 at PéryReuchenette). Through their stacking pattern and within the given bio-chronostratigraphic framework it can be shown that these small-scale sequences formed in tune with the orbital short eccentricity cycle of $100 \mathrm{kyr}$ (Colombié 2002; Strasser 2007). The basinal sections of Crussol and Châteauneuf-d'Oze are dominated by limestone-marl alternations. Each couplet is thought to correspond to the orbital precession cycle of $20 \mathrm{kyr}$. The 100-kyr cycles are visually less well expressed than in the platform sections. However, Boulila et al. (2008) performed a cyclostratigraphic analysis including the Châteauneuf-d'Oze section and confirmed the presence of the 100-kyr as well as the 400-kyr eccentricity cycles.

The maximum flooding of the large-scale (Kim2Kim3) sequence is indicated by a change from generally high-energy deposits to low-energy mudstones at Pichoux and Court (uppermost part of small-scale sequence 5). Even during maximum-flooding conditions water depth was very shallow to intertidal, as indicated by birdseyes and microbial mats. At Péry-Reuchenette, an equivalent facies change occurs 100 kyr later and coincides with the maximum-flooding surface of small-scale sequence 6 . In the basinal section of Crussol (and in several other sections of the Vocontian
Basin; Atrops 1982), the Ataxioceras lothari subzone comprises 16 limestone-marl couplets, corresponding to $320 \mathrm{kyr}$ (Hardenbol et al. 1998, indicated $300 \mathrm{kyr}$ ). At Châteauneuf-d'Oze, only 5 couplets are counted. At the base of the A.lothari subzone, the marly interval and a peak in manganese suggest condensation related to maximum flooding (De Rafélis et al. 2001). A second marly and thin-bedded interval with a manganese peak appears in the $C$.divisum zone. It corresponds to the condensed interval of the Kim2-Kim3 sequence identified by Hardenbol et al. (1998) in many other European basins. Correlating this interval up to the platform, it is seen to correspond to the maximum flooding identified at Péry-Reucenette (Fig.41). The equivalent of sequence boundary Kim3 of Hardenbol et al. (1998) is indicated by charophytes, black pebbles, dolomite, and birdseyes in the platform sections, and by thick limestone beds in the basin. It is situated in the $C$.divisum ammonite zone.

In the absence of laterally continuous outcrop in the vegetated Jura Mountains and in the absence of seismic lines, it is not possible to reconstruct the geometries of the sequence-stratigraphic elements. In the platform sections, the general facies trends within the large-scale Kim2-Kim3 sequence do not imply deepening or shallowing that would indicate retrogradation or progradation. However, many bedsets (small-scale sequences of Strasser et al. 1999) exhibit deepening-shallowing trends. It is therefore suggested that the Jura platform was in a general aggradational mode during this time but that high-frequency (orbitally controlled) sea-level fluctuations were superimposed on this long-term trend and controlled the facies evolution.

Across the whole platform, carbonate production was high enough to constantly fill in the available space, even during the transgressive part and the maximum flooding of the large-scale sequence. Tidal flats were common and islands with fresh-water lakes (as indicated by the charophytes) formed sporadically. The absence of karst or soils indicates that sea level never dropped below the platform edge and that the high-frequency sea-level fluctuations were of low amplitude. The fact that the studied large-scale sequence is significantly thicker at Péry-Reuchenette implies differential subsidence. The Jura platform was part of the northern passive margin of the Tethys Ocean where extensional block-faulting was common (Wildi et al. 1989).

The slump at Châteauneuf-d'Oze represents a lowstand deposit. The thick limestone beds at Crussol formed during lowstand but also during transgressive conditions when carbonate mud was exported from the 


\begin{tabular}{|c|c|c|}
\hline \multicolumn{2}{|c|}{ Facies } & Texture \\
\hline & limestone with quartz & marls \\
\hline 110 & limestone with dolomite & M mudstone \\
\hline - & peloids & W wackestone \\
\hline 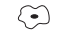 & oncoids & packstone \\
\hline$\odot$ & ooids & G grainstone \\
\hline$\Delta$ & lithoclasts & \\
\hline & black pebbles & Sedimentary structures \\
\hline$\star$ & echinoderms & birdseyes \\
\hline \& & foraminifera & bioturbation \\
\hline W & corals & $\simeq$ microbial mat \\
\hline \& & green algae & lamination \\
\hline$\smile$ & bivalves & \\
\hline \multirow{4}{*}{$\theta$} & gastropods & Sequence stratigraphy \\
\hline & & sequence boundary \\
\hline & & maximum flooding \\
\hline & & CS condensed section \\
\hline
\end{tabular}

Fig. 42. Legend for Fig. 41.

platform. During transgression, the energy on the platform was generally higher, which resulted in the recurring pack- and grainstones there. In the basin, a first condensed interval formed while on the platform no change in stacking pattern or facies is observed. The second condensed interval, however, corresponds to the shift from rather high-energy deposits to low-energy facies on the outer platform (Péry-Reuchenette). This shift, however, happened earlier in the platform interior (Pichoux and Court). Due to the high-frequency sea-level fluctuations that were superimposed on the long-term trend and due to the irregular platform morphology, the threshold apparently was not passed at the same time all over the platform. The highstand deposits are quite thin in the basin while they are well developed on the platform. According to the time-lines given by the cyclostratigraphic interpretation, the late highstand is much reduced in the platform interior while at Péry-Reuchenette subsidence was sufficient to accommodate thick peritidal deposits.

This case study demonstrates that the combination of sequence stratigraphy and cyclostratigraphy allows the reconstruction of systems tracts with a high time resolution. It is seen that the physical expression of sequence-stratigraphic surfaces (as defined by facies changes in the outcrop) can be shifted in time due to varying basin morphology and due to superposition of high-frequency sea-level fluctuations on a longer-term trend of sea-level change (Strasser et al. 2000). If a specific surface cannot be physically followed from one section to the other, it may therefore be of advantage to define 'sequence-boundary zones' or 'maximum-flooding intervals' (Montañez and Osleger 1993; Carter et al. 1998). This study emphasizes the complexity of carbonate systems where organic sediment production, sea-level changes, and subsidence patterns interact.

\section{Case study: Mid-Cretaceous carbonate platform of the Maestrat Basin, Iberian Chain}

The mid-Cretaceous carbonate system of the western Maestrat Basin in the Iberian Chain shows clear facies patterns and distinct key surfaces which enable sediment-body geometries to be defined and interpreted in terms of the 4-systems tract model of Hunt and Tucker (1992, 1995). Deposition during the late EarlyMiddle Aptian was controlled primarily by two orders of relative sea-level change, and the higher-frequency sea-level rhythms created four types of meter-scale cycle (Bover-Arnal et al. 2009). The lower-frequency cyclicity resulted in five well-differentiated systems tracts within two depositional sequences: a highstand systems tract (HST) and falling-stage systems tract (FSST) of depositional sequence A; and a lowstand systems tract (LST), transgressive systems tract (TST) and highstand systems tract (HST) of depositional sequence B (Fig. 43). The systems tracks could be separated and identified on the basis of well-developed key bounding surfaces, namely a basal surface of forced regression, a subaerial unconformity and its marine correlative conformity, a transgressive surface and a maximum flooding surface. These are all broadly identifiable and correlatable throughout the platform-tobasin transition.

The first HST of depositional sequence A consists of prograding rudist-coral framestones-rudstonesfloatstones. The succeeding FSST consists of a detached, slightly cross-bedded bioclastic pack/grainstone unit situated at the toe of the slope in a basinal position. The LST is characterized by a small carbonate platform dominated by rudists and corals, and this downlaps over the FSST and onlaps landwards over the sequence boundary. The TST exhibits platform backstepping and is composed of more marly, locally bioclastic wackestones. The second HST is characterized by prograding units of bioclastic, rudist-coral pack/grain- stones as high rates of carbonate production resumed on the platform and skeletal debris was supplied to the slope. Bover-Arnal et al. (2009) took the view that the sequence boundary should be placed above the forced regressive wedge, below the low- 

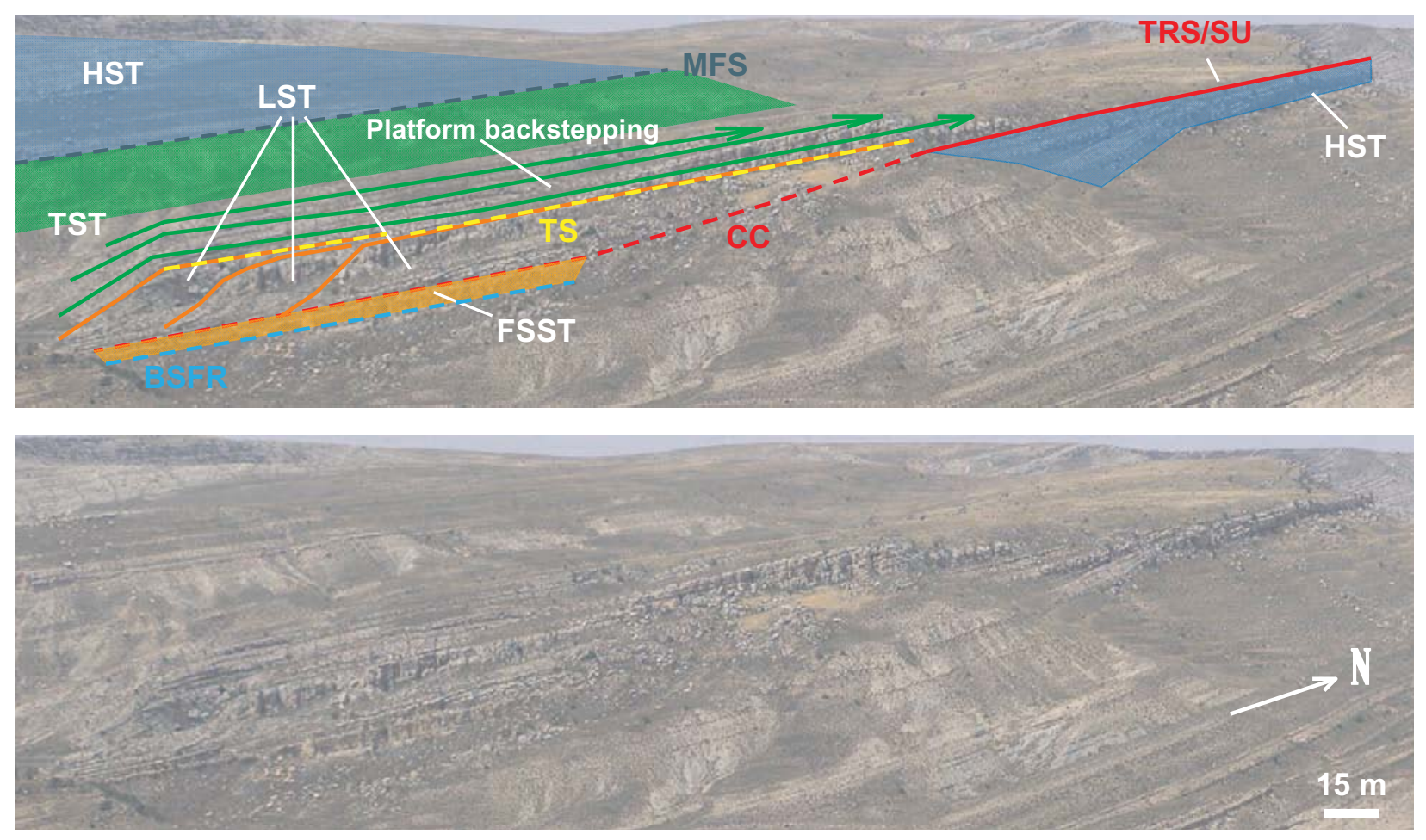

Fig. 43. Sequence stratigraphic framework of an Aptian platform-to-basin carbonate succession in the western Maestrat Basin (from Bover-Arnal et al. 2009). See Bover-Arnal et al. (2009) for full facies descriptions and interpretations. Abbreviations: HST - highstand systems tract; FSST - falling-stage systems tract; LST - lowstand systems tract; TST - transgressive systems tract; BSFR - basal surface of forced regression (= correlative conformity sensu Posamentier and Allen, 1999); CC - correlative conformity sensu Hunt and Tucker (1992); TS - transgressive surface (in this case, a transgressive ravinement surface reworking a maximum regressive surface); TRS - transgressive ravinement surface; SU - subaerial unconformity; MFS - maximum flooding surface.

stand prograding wedge. On a more regional, even global scale, these systems tracts occur within two larger-scale Aptian T-R sequences.

On a smaller scale, the Maestrat succession is made up of four types of meter-scale cycle resulting from higher-frequency sea-level fluctuations. These basically accretional units are composed of ten lithofacies associations, which are interpreted in terms of bathymetry, hydrodynamic conditions and trophic level of the various depositional environments. This Maestrat Basin carbonate platform had a flat-topped nonrimmed depositional profile with well-developed rudist-bivalve floatstones containing corals, interpreted as largely formed below wave-influence. For the most part, deposition of all these Aptian carbonates took place in low energy hydrodynamic conditions.

One feature of particular interest is that the major sea-level fall recorded in this succession at the end of the first HST during the uppermost early Aptian (Dufrenoyia furcata biozone) was likely on the order of tens of meters and appears to have been a global event. This fall that subaerially exposed the carbonate platform, led to the deposition of the FSST. Of the various mechanisms that could trigger a significant sea-level drop in less than $1 \mathrm{Myr}$, glacioeustasy was invoked and this event could correlate with the cooling episode proposed for this time slice (Hochuli et al. 1999; Steuber et al. 2005).

\section{Mixed carbonate-evaporite settings}

\section{Introduction}

In evaporite systems, precipitation takes place in a range of shallow- to deep-water environments at times of increased aridity (see review in Warren 2006). The majority of the world's thickest and most extensive evaporite successions were precipitated in intracratonic basins, which were separated from the world ocean by some barrier. Examples include the Zechstein, Williston-Elk Point, Michigan, Paradox, Delaware, 
Moscow and Siberian basins. In most of these, carbonate platforms developed around the basin margins when there was free circulation within the basins and open connection with the ocean. Evaporites were commonly precipitated in sabkhas and hypersaline lagoons, often extremely extensive, behind the carbonate rims. The evaporites within the basin centers, where the thickest successions occur (the saline giants), were precipitated at times of reduced connection with, or complete isolation from, the open ocean, through the operation of a sill or barrier. Once sea level has dropped below the height of the barrier to cut the basin off totally, then the basin may draw down very quickly through evaporation. Some water will seep into the basin through marginal permeable rocks, and there may be some reflux of hypersaline brines out of the basin. In a similar way, global sea level may only need to rise a few meters to overtop the barrier and flood the basin. Much greater and more rapid water-level changes can thus be expected within such silled basins compared with those normally considered for siliciclastics and carbonates deposited on passive margins and in other completely open basins. In addition, sea-water and brine levels within an isolated saline basin may vary independently of global sea level, responding especially to climate changes and tectonic effects.
In terms of sequence stratigraphic models for carbonate-evaporite basins, two principal types were distinguished by Tucker (1991), depending on the degree of drawdown: model 1, incomplete drawdown, giving marginal gypsum wedges and basinal laminated gypsum, and model 2, complete drawdown, giving halite basin-fills (Figs. 44, 45). More recent discussions of these and other aspects of evaporite sequence stratigraphy have been presented by Sarg (2001) and Warren (2006). The origin of sequences is generally assumed to be related to cycles of salinity change, but other ecological factors such as temperature may be equally important in controlling facies and faunal cyclicity in carbonate-evaporite settings (Pratt and Haidl 2008).

Prior to the onset of evaporite precipitation, an intracratonic basin is typically fully connected to the world ocean, with the sea level above sill height. Carbonate platforms will occur around the basin and extensive shallow-water biogenic and abiotic carbonate sedimentation will take place under the generally ideal hot and dry climate, where there is limited siliciclastic input. Retrogradational (TST) carbonates followed by aggradational-progradational (HST) shallow-water carbonates would be developed, with thin (condensed) pelagic carbonates and hemipelagic mudrocks within the basin center (Figs. 44.1, 45.1).

\section{1. highstand open basin, carbonate rim}

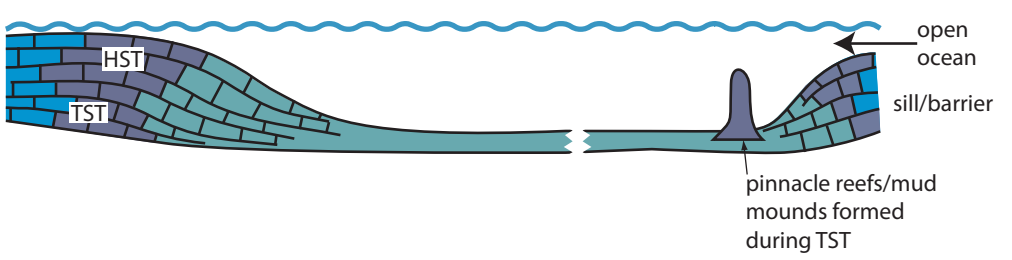

2. falling stage \& lowstand marginal gypsum wedge

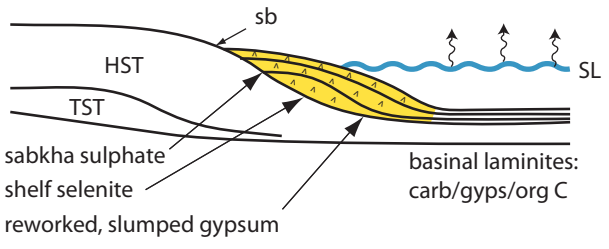

3. early TST retrogradational sabkha/evaporitic lagoons

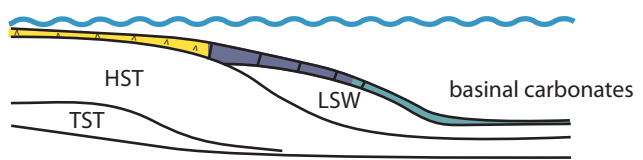

4. TST retrogradational carbonate

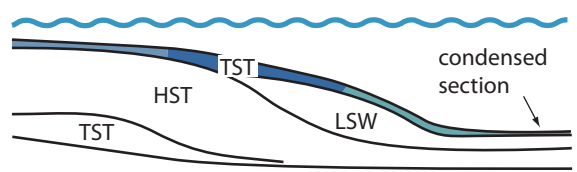

5. highstand rimmed shelf

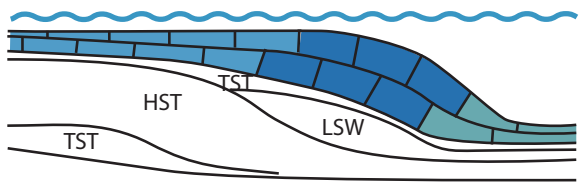

6. late HST sabkha/evaporitic lagoons

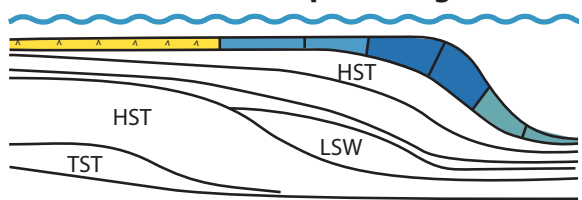

Fig. 44. Carbonate - evaporite intracratonic basins: sequence stratigraphic model for a basin with incomplete drawdown, leading to basin-margin gypsum wedges (from Tucker 1991). 


\section{1. highstand open basin, carbonate rim}

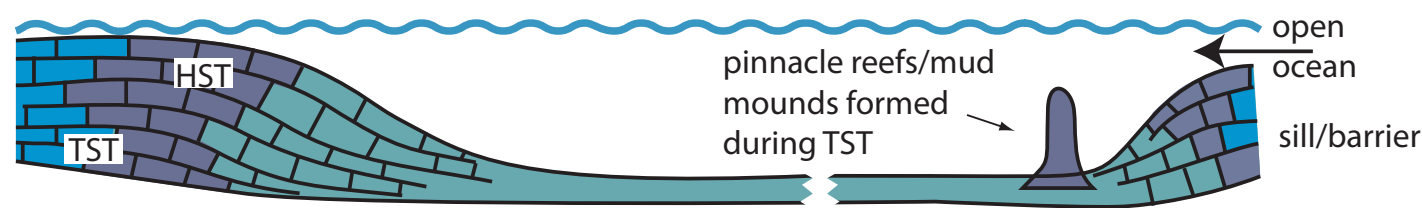

\section{2. falling stage $\&$ lowstand gypsum wedge during slow sea-level fall}

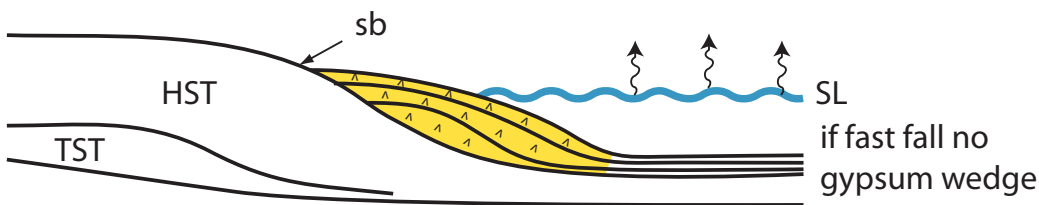

3. lowstand halite pans and lakes

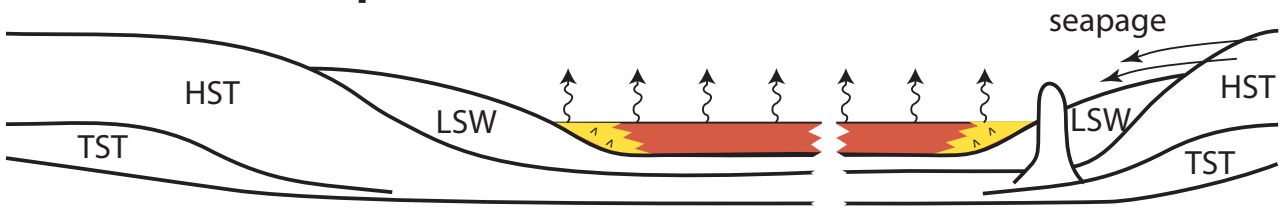

\section{4. basin-fill halite (BFH), early TST gypsum}
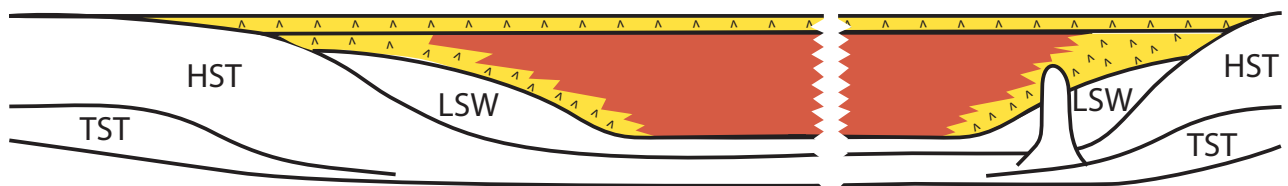

\section{5. highstand aggraded platform}

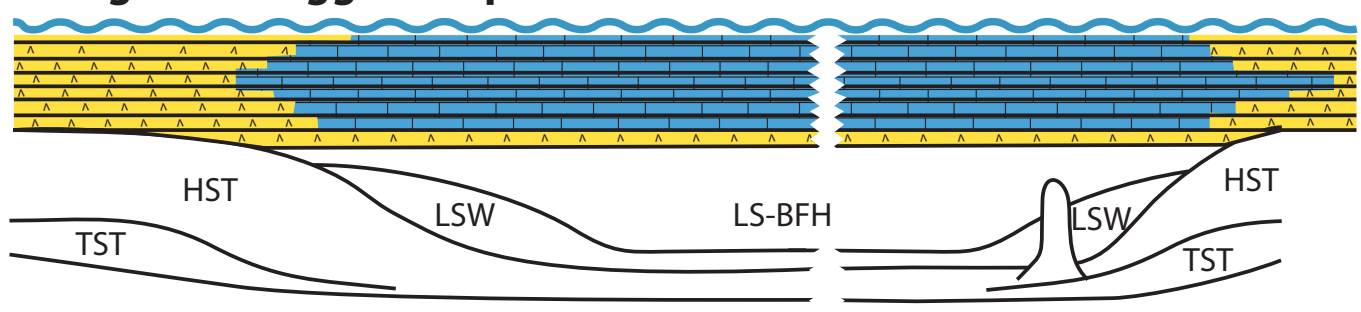

\section{6. highstand rimmed shelf/ramp through basin-centre subsidence}

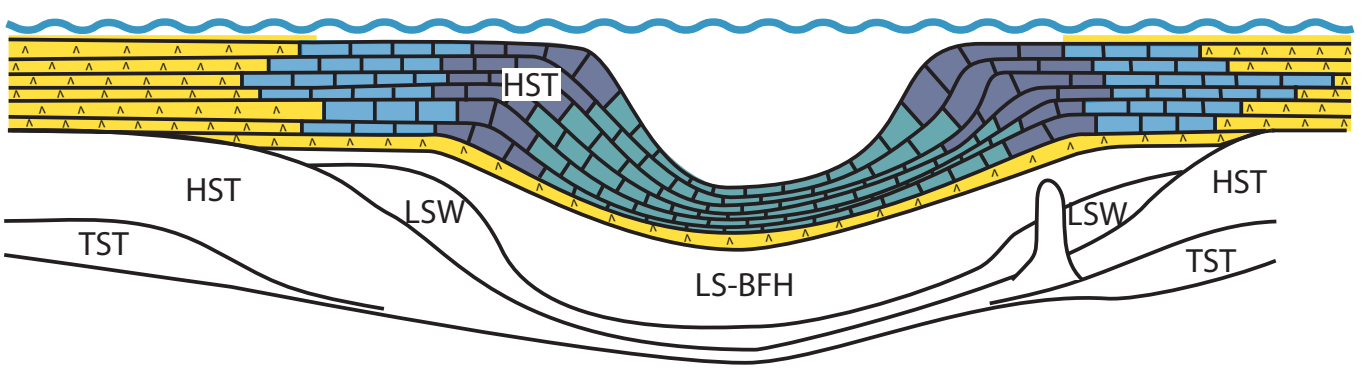

Fig. 45. Carbonate - evaporite intracratonic basins: sequence stratigraphic model for a basin with complete drawdown leading to basin-fill halite (from Tucker 1991). 


\section{Forced regression}

With a forced regression and sea-level falling close to or just below the sill height, the water level within the basin will quickly fall below the shelf break of the marginal carbonate platforms through evaporative drawdown. Water within the basin will rapidly become hypersaline, although some seawater replenishment may occur as a result of seepage through permeable carbonates near the barrier. Gypsum will precipitate in abundance around the basin margins during this FSST, below the carbonate platform rims, to initiate wedges (Figs. 44.2, 45.2). On the basin floor, carbonate will continue to be deposited in the early stages of drawdown until the basinal waters themselves are saturated for calcium sulphate.

During the falling stage and subsequent lowstand, the marginal carbonate platforms will be exposed and may be subjected to subaerial erosion, karstification and, potentially, massive dolomitization. Fluvial incision and siliciclastic influx may occur if there is hinterland topography, but under an arid climate the amount of sand supplied may be limited.

\section{Lowstand normal regression}

In the situation of incomplete drawdown, where the basin always contains some water through partial to near-complete isolation from the world ocean, extensive marginal gypsum wedges will prograde into the basin. Gypsum precipitation during this time of more stable sea level within the basin may take place in shallow, lagoonal hypersaline waters as selenitic gypsum. Gypsum platforms may form within the basin on local topographic highs, as occurred in Poland during the upper Permian (Slowakiewicz and Mikolajewski 2009). Meter-scale sedimentary cycles (parasequences) may be developed within the wedge if there are higher frequency relative water-level changes within the basin. Resedimentation of gypsum into deeper water by storms, slope failure, debris flows and turbidity currents will give graded beds, slumps and breccias, and contribute towards the progradation of the gypsum platforms. Within the basin center, fine-grained gypsum will be precipitated from surface waters on to the basin floor, and this may be interlaminated with carbonate and/or organic matter, reflecting seasonal variations in precipitation and plankton blooms. Salinity stratification of the water mass can be expected, and a pycnocline is likely to form too, through the weak circulation of water within the basin. This will enhance organic matter preservation. Selenitic gypsum may be precipitated on the basin floor if the water depth is below about $25 \mathrm{~m}$.
If the conditions for subaqueous gypsum precipitation within the basin center are maintained for a long period of time, a thick succession of sulphate laminites will form, perhaps with selenitic beds, and this could fill the basin. Such was the case in the Permian Castile Formation of Texas (Anderson et al. 1972). Reflux of brines out of the basin and/or a relative humidity control may be required to prevent halite precipitation.

A basin may endure complete drawdown during the lowstand, if there is a major drop in sea level well below sill-height or there is complete blockage of the basin entrance (Fig.45). If the climate is arid enough (atmospheric relative humidity below 76\%) and there is virtually no replenishment from the adjacent ocean or from surface run-off, then halite will be precipitated on the basin floor, with deposition taking place in salt pans and salt lakes (Fig. 45.3). If the lowstand follows a very rapid forced-regressive drawdown, there may be little gypsum precipitated in basin-margin wedges. If there is sufficient water seeping into the basin through permeable rocks at the sill, then enough halite may be precipitated to completely fill the basin (Fig. 45.4). Potash salts may form in instances of extreme desiccation.

\section{Transgression}

When the basin is reconnected to the open ocean, the formerly exposed carbonate platforms will be re-flooded and carbonate deposition may resume there in transgressive, retrogradational (TST) geometries (Figs. 44.3, 44.4). The early deposits of the TST along the shelf margin could still be evaporitic if hypersaline shallow waters were maintained long enough to establish sabkhas and salterns (Fig.44.3).

In a lowstand halite-filled basin, initial deposits of the TST would likely still be hypersaline (Fig.45.4). Dissolution of salts by the incoming seawater would maintain hypersalinity for a time. Gypsum sabkhas and lagoons could be established and extend back over the former marginal carbonate platforms. Where lowstand halite has completely filled the basin, all original topography will have been removed and, in the absence of any differential subsidence, succeeding transgressive carbonates will be deposited in an extensive shallow sea, and highstand carbonates could well show a restricted fauna with further evaporites (Fig. 45.5).

\section{Highstand normal regression}

Once a basin has been completely re-flooded and fully connected to the open ocean then normal shallow-marine carbonates can be expected again on the marginal platforms with highstand progradation (Figs.44.5, 
45.5). The area of shallow-water carbonate deposition could now be much more extensive in view of the formation of the gypsum wedges and platforms during the preceding forced regression and lowstand. The new carbonate shelf margin will be located along the outer (basinward) edge of the gypsum wedge. Around the inner margins of the platforms, sabkhas and hypersaline lagoons could be very extensive during the highstand, although not necessarily creating thick successions (Figs. 44.6, 45.5).

\section{Discussion}

Thick and relatively rapidly-precipitated evaporites can have a significant loading effect on the crust (Van der Belt and de Boer 2007). This may well lead to increased subsidence of basin margins and basin floors, thereby creating further accommodation for more evaporites (Fig. 45.6).

In terms of key surfaces, the depositional sequence boundary will occur on the upper surface of the platform carbonates, where it could be represented by a paleokarst, or evaporite residue from later dissolution of inner platform sabkha-lagoonal evaporites. Dolomites may occur and be related to the sequence boundary as a result of seepage reflux. The correlative conformity of this surface in the basin would be best taken at the base of the evaporites, as a major facies change but also marking the beginning of forced regression. This would also be at the base of gypsum-carbonate/carbonaceous laminites in the central part of the basin.

In a basin of incomplete drawdown, the sequence would consist of an evaporitic lower part (the forced regressive-lowstand gypsum wedge and succeeding early TST sabkha/lagoonal gypsum) passing up and laterally into platform carbonates of the TST and HST. In a basin of complete drawdown, forced regressive gypsum could be succeeded by extremely thick lowstand halite, before transgressive evaporites and then carbonates as the basin reflooded. Evaporites may also be present in the uppermost part of the sequence from deposition in late HST-early FSST sabkhas and hypersaline lagoons on the inner part of the carbonate platform. Thus, in addition to the controls of climate on evaporite occurrence, evaporite precipitation is much controlled by base-level change and accommodation. Evaporites occur in thick successions at basin margins and in basin centers predominantly during lowstands of sea level (global or regional). However, they may also

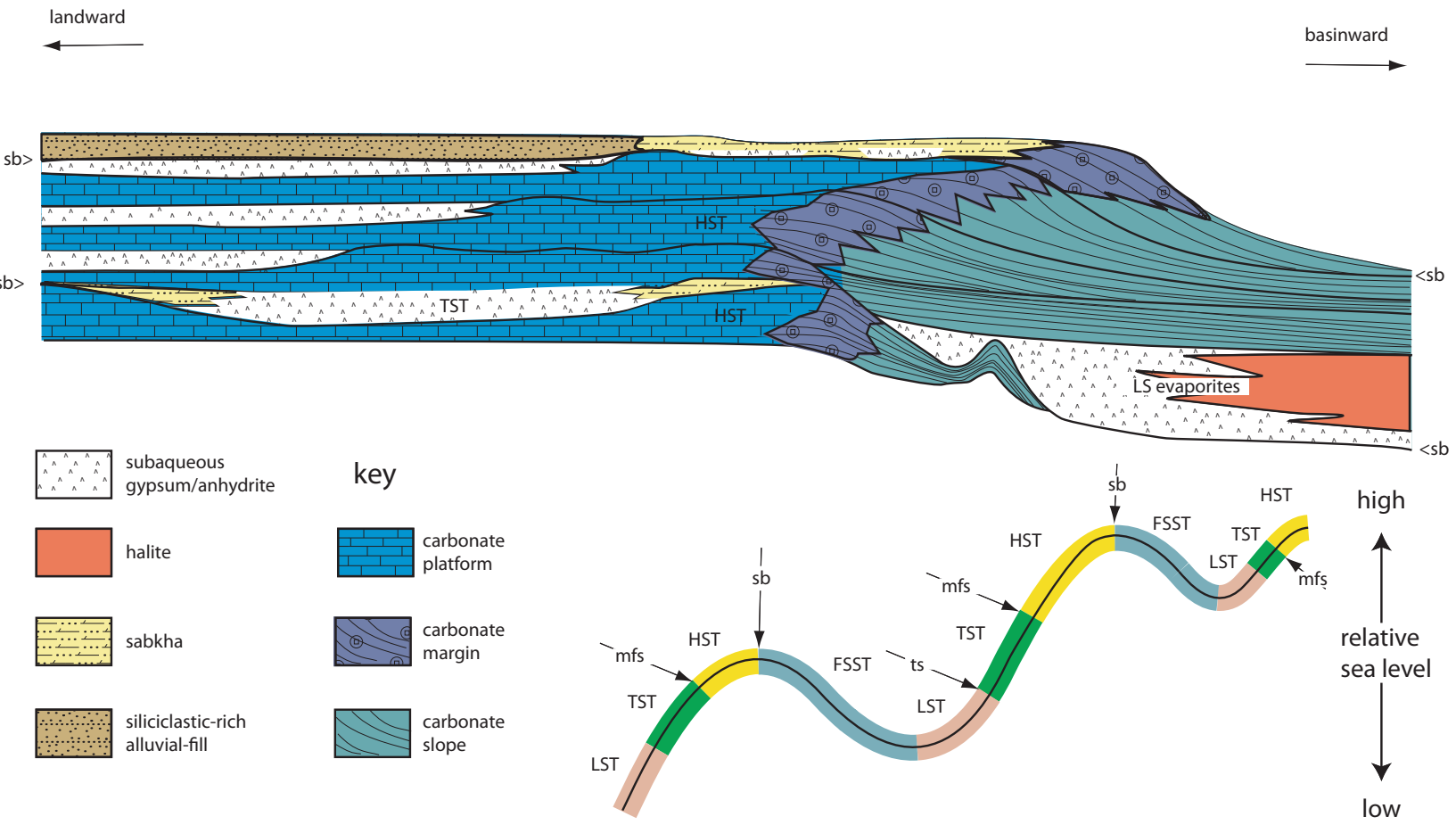

Fig. 46. Summary diagram of evaporite-carbonate lithofacies distribution in a sequence stratigraphic framework. Evaporites can occur within all systems tracts but are preferentially developed within the basin during falling-stage and lowstand systems tracts, and on the platform itself during early transgressive and late highstand to falling-stage systems tracts (after Sarg 2001). The designation of sequence boundary in this diagram conforms with Posamentier and Allen (1999). 
be precipitated in quite thick sections on platforms and shelves around basins during transgressive times when accommodation is being created. During highstands, evaporites may continue to be formed inboard of carbonate platforms, generating sabkha and other aridzone type cycles/parasequences, but these evaporites will generally be relatively thin. Figure 46 summarizes the sequence stratigraphic context of evaporites.

\section{Case study: The Upper Permian carbonate-evaporite succession (Zechstein) of NW Europe}

The Upper Permian Zechstein strata of NW Europe were deposited in the Southern Permian Basin, which stretched for $1500 \mathrm{~km}$ from eastern Britain to eastern Poland. The Zechstein succession has traditionally been described as a series of carbonate-evaporite cycles, five in total, which can be correlated across the whole basin with some local variations (Taylor 1990; Menning et al. 2006). Applying sequence stratigraphic concepts to the Zechstein (Tucker 1991) has some advantages since the stratigraphy of whole basin is considered rather that just the basin center as in the cycle concept. In addition, sequence stratigraphy extends the degree of prediction to the basin-margin platform carbonates and their diagenesis, that is not evident in a cycle approach.

In NE England, the first-cycle platform carbonates $(\mathrm{Z} 1 \mathrm{Ca}=$ Zechstein First-cycle carbonates) are the Raisby and Ford formations (equivalent to the Zechsteinkalk of continental Europe), with the first being a distally-steepened ramp deposit and the second a rimmed shelf (Figs. 47 and 48). Each of these platforms is one sequence (ZS1 and ZS2 = Zechstein Sequence 1 and 2), each dominated by transgressive and highstand carbonates, and the SB between the two is a karstic surface. A major slide deposit (megabreccia) was generated during the forced regression that terminated Raisby deposition.

Subsequently, the Zechstein basin was subjected to a partial drawdown and during forced regression and lowstand, the Hartlepool Anhydrite (= Werra) was precipitated as a $180 \mathrm{~m}$ thick and $30 \mathrm{~km}$ wide gypsum wedge, against the former shelf-margin carbonate slope. Much of the anhydrite is nodular, but this could well be a replacement of selenitic gypsum, precipitated in shallow water. Slumps, debrites and turbidites have been described from the Werra Anhydrite of Germany and the Netherlands. In the southern North Sea and Poland, halite units occurring within the anhydrite were precipitated in salt lakes.
The succeeding carbonates (Roker Formation, equivalent to the Main Dolomite of Poland, second Zechstein cycle carbonates, $\mathrm{Z} 2 \mathrm{Ca}$ ), are transgressive and highstand systems tracts, and with the underlying evaporites form Zechstein sequence 3 (ZS3). The Roker mostly consists of shelf-margin oolite (60 m thick) with microbial bioherms. The shelf margin was now more basinward than the earlier carbonate margin as a result of the development of the gypsum wedge. The foreslope facies (110 m thick) consists of graded beds, slumps and laminites, with well-developed cycles controlled by millennial-scale and Milankovitch rhythms (Mawson and Tucker 2009). To landward, marls and evaporites were deposited in shelf lagoons and sabkhas, mainly during the highstand.

Another forced regression and lowstand led to the precipitation of further evaporites: the Fordon Evaporites (= Stassfurt in continental Europe). Marginal gypsum wedges were formed but in contrast to the earlier Hartlepool-Werra evaporites, the basin was subjected to complete drawdown and so was completely filled with halite (thickness exceeding $300 \mathrm{~m}$ ). Late-stage polyhalite attests to extreme desiccation. In the basin center, the uppermost part of the evaporite section above the halite is a very persistent anhydrite bed (the Deck Anhydrite); this represents the early stage of the succeeding transgression. Overlying carbonates $(\mathrm{Z} 3 \mathrm{Ca}$, Seaham Formation, Plattenkalk in Poland, maximum $100 \mathrm{~m}$ thick) are uniform, peloidal mudstone to packstone, locally oolitic and bioclastic (restricted fauna), with crosslamination and local storm bedding. This aggraded shelf deposit extended for at least $100 \mathrm{~km}$ before passing into deeper-water laminated carbonates, since now much of the basin accommodation was filled with evaporites. The Hartlepool-Werra evaporites (FSST, LST) and succeeding Seaham-Plattenkalk carbonates (TST, HST) comprise Zechstein sequence 4 (ZS4).

The top part of the Zechstein succession, the third to fifth carbonate-evaporite cycles, generally has less carbonate, more clastics and thinner evaporites, of which some are potash facies, especially carnallite $(\mathrm{KCl})$. With these facies, deposition took place in sabkha, lagoonal and lacustrine environments, with clastics from coastal plains and distal alluvial fans, the whole succession now becoming much more continental. These deposits could be subdivided into three sequences, but they are relatively thin, and so could be regarded as higher-frequency cycles (parasequences) of one sequence (ZS5).

Examining a carbonate-evaporite succession in terms of its chronostratigraphy (Fig.48) is instructive. This 


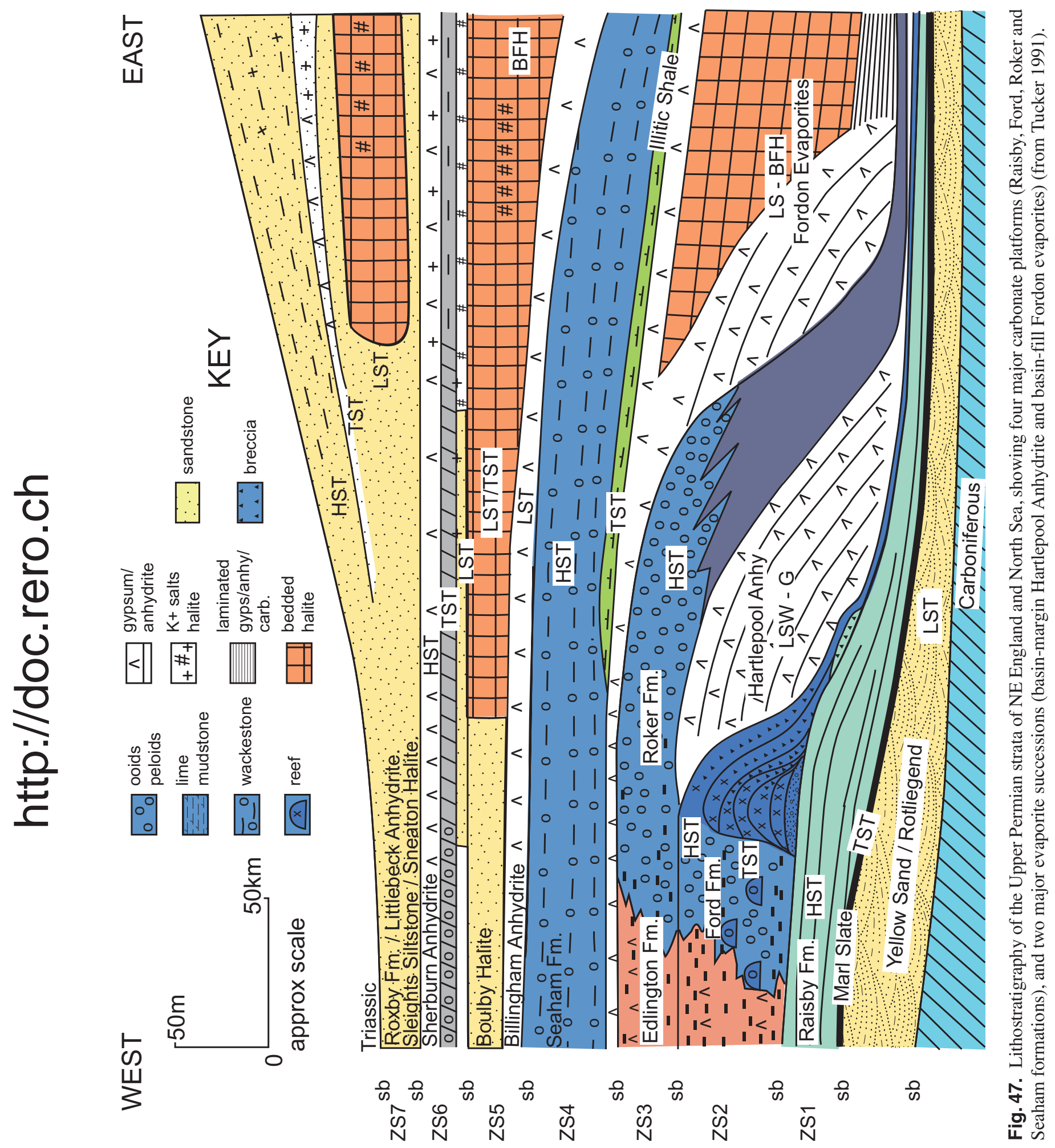




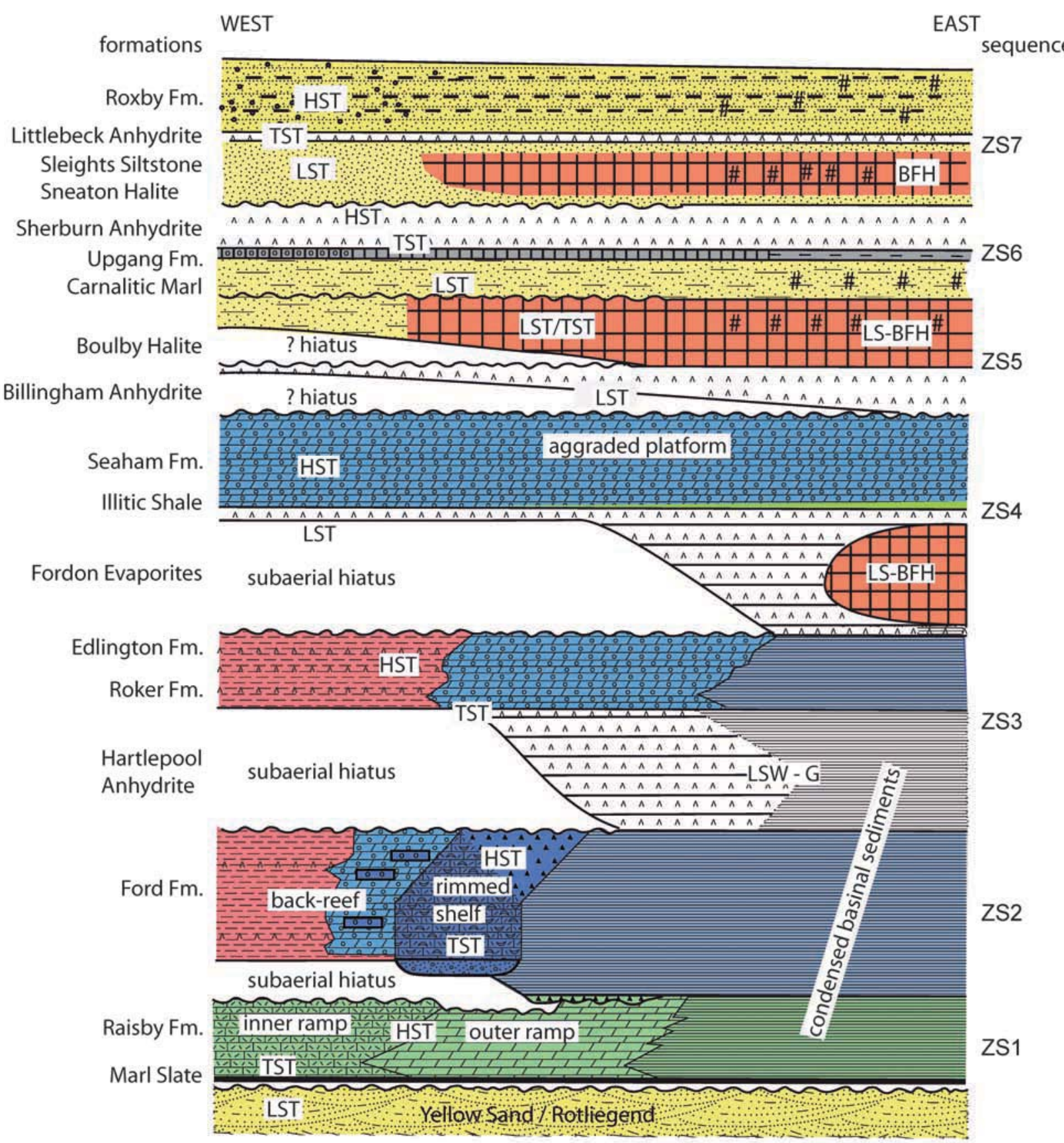

Fig. 48. Chronostratigraphy of the Permian Strata of NE England and the adjoining North Sea (from Tucker 1991).

approach highlights the stratigraphic breaks, which primarily occur on the platforms surrounding the basin at times when thick units of evaporites were being precipitated in the basin. Platform sequences are dominantly transgressive to highstand carbonates with increasing evaporitic deposition towards the top of the highstand, and with platform interior sabkha-saltern parasequences. By way of contrast, basin center sequences are falling-stage and lowstand evaporites (laminated gyp- sum/anhydrite and bedded halite), passing up into transgressive-highstand pelagic, starved-basin, condensed organic-calcareous rhythmites, possibly with highstand calciturbidites derived from adjacent platforms.

In recent years, other sequence stratigraphic interpretations have been published for the Zechstein of NW Europe including Strohmenger et al. (1996) for Germany, Peryt and Wagner (1998) and Slowakiewicz and Mikolajewski (2009) for Poland. Differences re- 
late to decisions of where to place the sequence boundary, and more data being available (from core and well-logs) on evaporite facies, especially relating to deposition during the late HST, and evaporite reworking during the late LST-TST.

\section{Mixed carbonate-siliciclastic settings}

\section{Introduction}

Terrigenous material generally has a detrimental effect on carbonate production, affecting the carbonate-secreting organisms in several ways. Turbidity caused by fine-grained material in suspension affects organisms by reducing light penetration, driving animals and plants to live at shallower depths, while clogging up their feeding mechanisms. Sudden influxes of terrigenous mud and sand can smother and bury organisms, and high nutrient levels which often accompany terrigenous input, can lead to intense microbial activity. This has a deleterious effect on many higher organisms which produce carbonate skeletal material since many are oligotrophic. Carbonate-producing organisms however have made many adaptations to clastic input and there are also many examples today where such animals are happily growing in areas of terrigenous sedimentation. This can lead to the formation of patch reefs on clastic shelves for example (e.g., the inner part of the Queensland shelf, inboard from the Great Barrier Reef; Larcombe et al. 2001), or to reefs growing on abandoned delta-front bars in areas dominated by terrigenous mud (e.g., the Mahakan Delta, Indonesia; Wilson and Lockier 2002). In the Red Sea, coral reefs are in close proximity to wadi-fan delta systems which periodically shed clastics over the reefs (e.g., Tucker 2003). There are numerous examples in the geological record of reefal carbonates associated with clastics (e.g., Santisteban and Taberner 1988; Braga et al. 1990).

Mixed-lithology sequences are of two broad types. In some cases the clastics, generally fine- to coarsegrained, occur above carbonates towards the top of a sequence (lower carbonate - upper clastic sequences), whereas in others, the clastics, dominantly mudrocks, occur in the lower part of the units, beneath the carbonates (lower mudrock - upper carbonate sequences). These mixed-lithology packages are developed where carbonate platforms are attached to terrigenous source areas (deltas, coastal mudflats) or where there is an axial supply of clastic material to the basin, through long- shore-drift and shoreline-parallel currents in shelf environments, and contour-flowing currents, tide-induced or wind-driven circulations dispersing micrite in slopebasinal environments. The clastic input is mostly controlled by sea-level and base-level changes, or through fault-related uplift, advancing thrust sheets as in foreland basins, or climatic effects. Clastic input and distribution, however, is not restricted to low stands of sea level, as commonly supposed.

\section{Lower carbonate - upper fine-to-coarse-clastic sequences}

Following the deposition of transgressive and highstand platform carbonates, which may involve slope progradation through clinoforms, clastic sediments are commonly deposited during the late highstand-forced regression-lowstand. Prograding clastic shorelines, fluvial plains and aeolian sand sheets may develop during the late highstand along the platform interior. During the forced regression, palaeosoils may form on the platform top, and incised valleys cut into the platform. Clastic sediment supplied to the basin during the FSST and lowstand will lead to lowstand wedges on the lower foreslope of the platform and the basin floor. This is the notion of reciprocal sedimentation: lowstand shedding of clastics and highstand shedding of carbonates (Van Siclen 1958). This occurs in the slope and basinal deposits of the Quaternary of the Caribbean area (Schlager et al. 1994) where clastic input to the deep sea was much greater during glacial times and carbonate production was higher during the interglacials when platforms were flooded. Ancient examples are documented from the Cambrian of northern Greenland (Ineson and Surlyk 2000), Devonian of the Canning Basin (Southgate et al. 1993; Playford et al. 2009), the Permian of Texas (e.g., Saller et al. 1989), and the Tertiary of northeast Australia and Gulf of Papua (Davies et al. 1989).

A further type of lower carbonate-upper clastic sequence occurs where transgressive carbonates are overlain by highstand clastics. In many cases, the lower carbonate has been initiated by rapid sea-level rise with little time for reworking of the coastal plain clastics below. This scenario requires a plentiful supply of terrigenous material to generate the upper clastic unit, usually a coarsening-upward deltaic or shoreline package. This type of sequence is well-known from the mid-Carboniferous of North America (e.g., Soreghan 1997; Rankey et al. 1999; Miller and Eriksson 2000; Smith and Read 2001) and from western Europe, and is described below as a case study. 


\section{Lower mudrock - upper carbonate sequences}

Basinal-outer shelf mudrock through to shallow-water limestone sequences, typically several 100 meters thick, are characteristic of carbonate ramp successions. They may themselves contain an internal smaller-scale cyclicity. Examples of these occur within the Carboniferous strata of South Wales (Burchette and Wright 1992), Triassic Muschelkalk of Germany (Aigner 1984) and the Cretaceous of the central and western Pyrenees (Simo 1989; Lenoble and Canerot 1993) and Austrian Alps (Sanders and Hofling 2000). Broadly, the deeper-water mudrock lower parts represent transgressive facies, while the upper carbonates were prograding shallow-water highstand facies. The 'Grand Cycles' of the Cambrian of the Rocky Mountains (Canada), Appalachians (USA; Glumac and Walker 2000), Canada (Aitken 1978), China (Meng et al. 1997) and elsewhere, are of this type. The terrigenous muds may be supplied axially into the basin, rather than across the drowned carbonate platforms. This is particularly true of foreland basins and narrow extensional basins, where carbonate platforms may be preferentially developed on one side.

\section{Discussion}

With the different types of mixed-lithology sequence, the lithofacies succession depends on the rate of sealevel change and availability of clastics. Slow sealevel rises can lead to extensive reworking of coastalplain clastics and so well-developed clastic lower parts to cycles representing transgressive units. More rapid sea-level rises cause flooding of coastal plains and so little reworking of sediment, especially if there had been extensive pedogenesis and/or vegetative cover, such that ravinement erosion was limited. At the other end of the sea-level cycle, stillstands allow coarsening-upward alluvial-plain, shoreline and deltaic facies to prograde over late transgressive-early highstand carbonates, with accommodation space determining thickness. A forced regression leads to platform exposure, river incision and the formation of lowstand fans and wedges on the basin-margin/toe of slope and incised-valley fills on the platform-top.

Mixed carbonate-clastic sequences are best developed at times of high amplitude sea-level change, and since these are typical of icehouse conditions, they are well-represented in the Quaternary and Permo-Carboniferous. During these times the high-frequency sealevel fluctuations were on the scale of 10's of meters and this was sufficient to bring terrigenous sediment into the depositional environment during a sea-level fall. The Permo-Carboniferous was also a time of firstorder sea-level lowstand, when more of the continental landmasses were exposed for weathering, erosion and denudation than at other times. The late Paleozoic was also a period of supercontinent assembly, when mountain ranges were forming, being uplifted and eroded.

During greenhouse times, lower- and mid-Paleozoic and Mesozoic, low amplitude sea-level changes were the norm and extensive carbonate platforms and clastic shelf seas were typical. Most shallow-marine, continental-shelf sequences of these periods are composed of single, uniform lithofacies, all clastic or all carbonate. The mixed lower carbonate-upper clastic sequences discussed here were rarely developed.

\section{Case study: Mixed carbonate-clastic sequences, Mid-Carboniferous, northern England}

The Carboniferous period was a time of developing glaciation in Gondwana (Wright and Vanstone 2001) and successions of this time in most parts of the world are markedly cyclic, which is usually attributed to glacioeustasy, although tectonic overprinting can mask the orbital-forcing signal (e.g. Wilkinson et al. 2003). In Europe Lower Carboniferous cycles commonly involve carbonates, while the Upper Carboniferous cycles are more clastic, with the Coal Measure cyclothems of the Westphalian being classic examples. In Northern England, in the upper Viséan through Serpukhovian, the cycles are typically mixed lower carbonate-upper clastic facies, referred to as 'Yoredale cycles'. The lower carbonate part is up to 30 meters thick, overlain by a clastic section, locally with a thin coal seam at the top (Tucker et al. 2009). These cycles vary in thickness from 5 to $70 \mathrm{~m}$.

The Yoredale limestones are typically well-bedded muddy bioclastic packstones-wackestones with a diverse fauna. Locally there are small biostromes of colonial corals or beds of solitary coral. The basal bed (up to $0.5 \mathrm{~m}$ thick) of some limestones is a prominent sand-rich or clay-rich bioturbated bioclastic packstone with fish scales with the clastic material derived from reworking of the top of the cycle below. Limestones were deposited in water depths of 10-40 meters, in a generally quiet environment with occasional storms. This was effectively an extensive and flat, low-energy epeiric-type platform, probably $150 \mathrm{~km}$ across, covering $10,000 \mathrm{sq} \mathrm{km}$, with a gentle slope with micrite mounds and debrites into deeper water of the Central Pennine Basin to the south. 


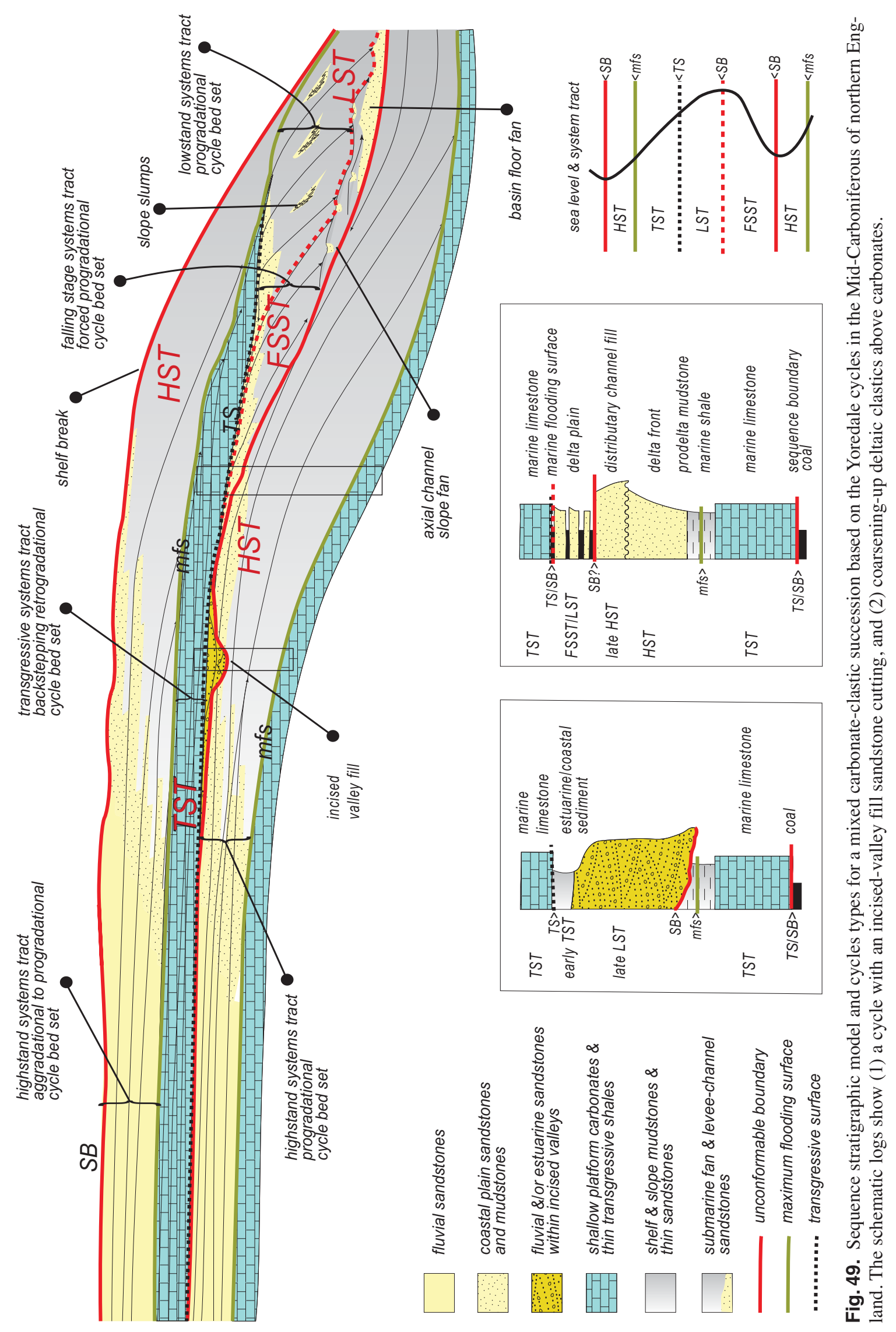


Two main types of clastic succession occur above the limestone in a Yoredale cycle: (1) a dominantly deltaic unit of prodelta mudrocks passing up into distal mouth-bar then proximal mouth-bar sandstones. In some cases a distributary channel sand-body, several meters thick, cuts down into mouth-bar sandstone (see Fig. 49, right-hand $\log$ ); and (2) a deep- to shallowmarine succession of mudrocks to sandstones with tempestites and HCS from storms and a range of trace fossils, and then shoreface-foreshore cross- and flatbedded sandstones.

At several horizons in the succession, major lenticular, cross-bedded, coarse sand bodies cut down 10 meters or more into the coarsening-upward unit, in some cases reaching the limestone at the base of the cycle (see Fig.49, left-hand log). These shoestring sand-bodies show a fining-up of grain-size and a decrease of cross-bed set thickness, and in some cases wave-ripples and burrows towards the top. These sandstones are interpreted as incised-valley fills.

At the top of the Yoredale cycles, there is usually a palaeosoil (seatearth, fireclay, underclay, ganister, calcrete) of variable grain-size, colour, thickness and texture, reflecting the climate of the time. A thin coal seam may complete the cycle. One or several meterscale ('minor') coarsening-upward cycles may also occur at the top of a cycle. These coastal-plain facies result from small deltas filling lakes and bays.

The Yoredale cycles show all the features of fully developed sequences that include all systems tracts (Tucker et al. 2009; Figs. 49, 50). The limestones constituting the lower parts of the Yoredale cycles represent the transgressive systems tracts (TST). The passage up into the overlying mudrocks is equivalent to the maximum flooding. The succeeding coarseningupward, shallowing-upward deltaic facies represent the highstand systems tracts (HST), and the thin coals and paleosoils at the top of a typical cycle are the late HST/ FSST-LST/early TST. The incised-valley fills downcutting into the HST facies represent the falling-stage (FSST) and lowstand (LST) systems tracts, of fluvial through estuarine facies, then succeeded by transgressive carbonates of the next sequence. The IVFs occur at specific stratigraphic horizons and represent times of sharper and deeper glacioeustatic sea-level falls. The valleys would have fed lowstand fans and wedges located in the Central Pennine Basin to the south.

The cyclicity which so dominates Carboniferous sedimentary successions was largely produced by glacioeustatic changes in sea level as a result of orbital forcing and variations in solar insolation. Notwithstanding the dominance of orbital forcing, there were

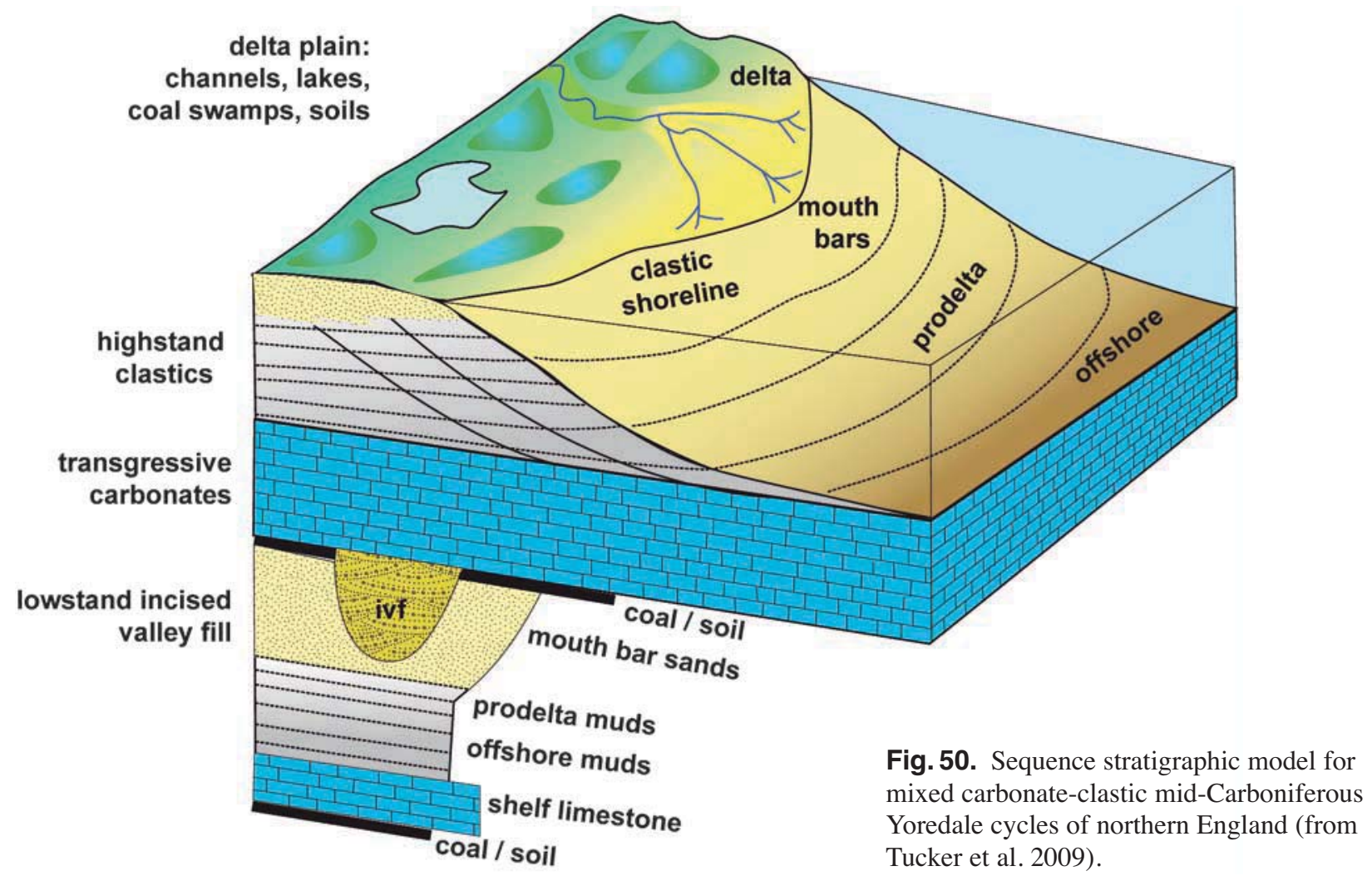


locally tectonic and sedimentary controls on deposition too. There have been numerous papers discussing the periodicity of Carboniferous cycles in Europe and North America, with the consensus favouring the eccentricity rhythm, but arguments over whether the short or long eccentricity was the control (e.g., Smith and Read 2000, 2001 versus Wright and Vanstone 2001). Davydov et al. (2010) have dated major PermoCarboniferous oscillations as $100 \mathrm{kyr}$ with $400 \mathrm{kyr}$ modulation.

The origin of the Yoredale cycles specifically has been much discussed with tectonic, eustatic and sedimentary mechanisms all put forward. Broadly similar patterns of cycle thickness variation across the region support the role of eustasy and/or regional tectonics (subsidence), although there may well have still been local tectonic (i.e., fault) or sedimentary controls.

\section{Part three - \\ Discussion and conclusions}

\section{Links to other stratigraphic disciplines}

Sequence stratigraphy relies on other stratigraphic disciplines to constrain the correlation of surfaces and systems tracts and to estimate the time involved in the formation of a sequence. Lithostratigraphy allows short-distance correlations in aggradational intervals where facies changes occur simultaneously over the studied area. Allostratigraphy uses discontinuities and surfaces that are assumed to have a time-stratigraphic significance. Thus, it can be considered as being a part of sequence stratigraphy.

Biostratigraphy is needed to tie the studied sequences to the chronostratigraphic time frame. Magneto- and chemostratigraphy help in fine-tuning the chronostratigraphy by furnishing precise correlations (Langreis et al. 2010; Weissert et al. 2008). There may also be a genetic link between biostratigraphy and sequence stratigraphy because sea-level changes may force biological evolution (e.g., Cecca et al. 2005; Sandoval et al.2008). A genetic link may also exist between sea-level changes and the chemical composition of the ocean because they are related to the same driving forces such as ocean-floor spreading and climate changes (e.g., Weissert and Mohr 1996; Weissert et al. 2008).
Cyclostratigraphy has a high potential to refine the sequence-stratigraphic analysis. It uses astronomical cycles of known periodicities (Berger et al. 1989) to interpret repetitive patterns in the sedimentary record (e.g., Strasser et al. 2006) and to establish astrochronological time scales (e.g., Hinnov and Ogg 2007). Astronomical cycles cause insolation changes at the top of the atmosphere, which then translate into climate changes and eventually into eustatic sea-level changes, mainly through glacioeustasy and thermal expansion and retraction of the uppermost layer of ocean water. Eustatic sea level, together with subsidence, controls accommodation. A sedimentary sequence created by an orbitally controlled sea-level fluctuation thus can potentially be interpreted in terms of sequence stratigraphy (Vail et al. 1991; Strasser et al. 1999).

In many cases, parasequences (Van Wagoner et al. 1990) or simple sequences (Vail et al. 1991) can be shown to have formed in tune with orbital cycles. The stacking pattern that is commonly used in sequence stratigraphy to define retrogradational, aggradational, or progradational trends may reflect the hierarchy of orbital cycles. Care has to be taken in the interpretation, however, because not all cycles are recorded if no threshold was passed to create a recognizable facies contrast, or if there was non-deposition or erosion ('missed beats'; Goldhammer et al. 1990). The effect of orbital cycles on sedimentation may also vary with the tectonic and depositional setting. For example, epicontinental seas are particularly sensitive to climatic fluctuations, and prone to changes in water temperature and salinity that may result in the formation of regional sequences (Pratt and Haidl 2008). The superposition of high-frequency sea-level fluctuations on a longer-term trend may add another degree of complexity to the stratigraphic record by producing intervals of repeated sequence-stratigraphic surfaces rather than a single surface (Montañez and Osleger 1993; Strasser et al. 2004). Furthermore, autogenic processes may produce sequences and surfaces that are independent of accommodation changes (e.g., Martin et al. 2009).

\section{Sequence stratigraphic methodology}

Perhaps the most significant progress in sequence stratigraphy is the shift from models to methodology (Fig. 19). The debates that punctuated the last three decades (Figs. 1, 2) led to the realization that all approaches are correct under the specific circumstances 
for which they were proposed (Catuneanu et al. 2009, 2010). A standard methodology can be defined based on the common ground between the different approaches, with emphasis on the observation of stratal stacking patterns in the rock record. Various data sets can be used for this purpose, including outcrop, core, well-log and seismic data. Each data set may be more suitable to a particular scale of observation, and may provide different insights toward the identification of stratal stacking patterns and key bounding surfaces. Mutual corroboration, wherever possible, is desirable.

A great deal of disagreement was fueled by arguments regarding the selection of sequence boundaries among the set of sequence stratigraphic surfaces. Early models also promoted the idea that sequence stratigraphic surfaces are time lines and correlatable world wide, which sparked intense debates and controversy. It is now clear that both global and local controls may contribute to the sequence stratigraphic framework of every sedimentary basin, and that no model can replace the value of data and observation. It was demonstrated that all sequence stratigraphic surfaces may have physical expression in outcrop (e.g., MacEachern et al. 1999; MacNeil and Jones 2006; Bover-Arnal et al. 2009), and that they all are potentially diachronous (e.g., Catuneanu 2006). These developments reiterate the importance of field criteria to the delineation of any type of sequences stratigraphic unit and bounding surface, and the fact that all sequence stratigraphic approaches are data driven.

Sequence stratigraphic units (i.e., sequences, parasequences, systems tracts) are defined by their bounding surfaces. The definition of units is independent of temporal and thickness scales, and therefore the scales of different types of unit may overlap. Sequences and parasequences correspond to cycles of change in stratal stacking patterns, which are interpreted to reflect cycles of change in accommodation or sediment supply. These cycles are defined by the recurrence of the same types of stratigraphic surface in the rock record, whether subaerial unconformities (in the case of depositional sequences), maximum flooding surfaces (in the case of genetic stratigraphic sequences), maximum regressive surfaces (in the case of T-R sequences) or flooding surfaces (in the case of parasequences). In contrast with sequences and parasequences, systems tracts correspond to only portions of full cycles, and therefore they have different types of bounding surface at the base and at the top.

Stratal stacking patterns describing normal regressions, transgressions or forced regressions can succeed each other in any order, as a function of syn-depositional conditions and/or post-depositional preservation. Sequences may consist of any combination of these types of deposit, and may or may not include all three types of deposit. However, all sequences whose timing and origin relate to shoreline trajectories share the common element that they all consist of a combination of the same types of (normal regressive, transgressive and forced regressive) stacking patterns. Notably, the same kinds of stacking patterns compose any type of sequence stratigraphic unit, from sequence to systems tract and parasequence. This means that a methodology that focuses on stratal stacking patterns provides an objective, model-independent workflow to the standard application of sequence stratigraphy (Fig. 19).

The sequence stratigraphic method must be kept independent of assumptions regarding the controlling mechanisms on sequence development. It has become increasingly evident that a range of allogenic processes may operate over similar temporal scales to control the development of depositional patterns and stratigraphic cycles. Accommodation curves may be reconstructed based on geometries preserved in the rock record, including the thickness of topsets that form during normal regressions, the increase in the relative elevation of backstepping (transgressive) coastlines, the magnitude of downstepping during forced regressions, or the depth of fluvial incised valleys. However, such quantitative curves may only have local relevance due to variations in tectonic regimes and sediment supply from one sedimentary basin to another, or between different sub-basins within the same sedimentary basin.

The scale of observation is a critical aspect of sequence stratigraphic work; it may be selected on purpose according to the scope of the study (e.g., petroleum exploration versus production development) or it may be imposed by the resolution of the available data. For example, outcrops and well-log data may support high-resolution sequence stratigraphic studies, suitable for understanding reservoir compartmentalization, whereas seismic data afford lower resolution studies, more suitable for the purpose of petroleum exploration. The relative significance of sequence stratigraphic units that develop at different scales of observation is resolved via the concept of hierarchy.

Different proposals on how to define a hierarchy system (e.g., Vail et al. 1977, 1991; Mitchum and Van Wagoner 1991; Embry 1995; Krapez 1996, 1997) have stimulated active discussions within the stratigraphic community (e.g., Miall 1995, 1997; Drummond and 
Wilkinson 1996; Schlager 2004; see recent summaries in Catuneanu et al. 2009, 2010). A factor that limits the definition of a universally applicable hierarchy system is that the interplay of competing sequence-forming mechanisms results in the formation of stratigraphic cycles across a continuum of temporal and spatial scales (Drummond and Wilkinson 1996; Schlager 2004). In the absence of discrete modes within the wide continuum of scales, hierarchical subdivisions often remain arbitrary and may only be basin specific (Catuneanu et al. 2009, 2010).

In this paper we aim to clarify and streamline the sequence stratigraphic terminology and methodology for a more user-friendly and model-independent application in all types of academic or industry-oriented research. This model-independent approach is meant to release sequence stratigraphy from the straitjacket imposed by the requirements of any specific sequence stratigraphic model, and stimulate the flexibility that is needed to adapt to the particularities of any case study. The proposed streamlined methodology permits the construction of sequence stratigraphic frameworks that are best fitted to the available data.

Acknowledgements. This paper is the result of the continuing effort to provide a neutral platform for the inclusion of sequence stratigraphy in international stratigraphic guides and codes. Work started in 2006 with the premise that a large and inclusive working group is required for this task. We acknowledge the significant contributions brought by all members of this working group, which, in addition to the authors of this paper, includes V.Abreu, J.P. Bhattacharya, M.D.Blum, R.W.Dalrymple, P.G.Eriksson, C.R.Fielding, W.L.Fisher, P. Gianolla, M.R.Gibling, K. A. Giles, J. M.Holbrook, R. Jordan, B.Macurda, O.J.Martinsen, J.E.Neal, D.Nummedal, L.Pomar, B.R.Pratt, J.F.Sarg, K.W.Shanley, R. J. Steel and C. Winker. With this paper we build upon the work published by Catuneanu et al. $(2009,2010)$.

We thank Brian Pratt (Chair, ISSC) for his exceptional support, guidance, and feedback throughout the process leading to this publication. We also thank all members of the International Subcommission on Stratigraphic Classification (ISSC) of the International Commission on Stratigraphy who provided useful and constructive comments on earlier versions of the manuscript.

The publication of this work in full colour was made possible by the generous support provided by Chevron Energy Technology Company.

\section{References}

Aigner, T., 1984. Dynamic stratigraphy of epicontinental carbonates, Upper Muschelkalk (M. Triassic) South German Basin. Neues Jahrbuch für Geologie und Palaeontologie, Abhandlungen 169, 127-159.

Ainsworth, R.B., 1991. Sedimentology and high resolution sequence stratigraphy of the Bearpaw-Horseshoe Canyon transition (Upper Cretaceous), Drumheller, Alberta, Canada. M.Sc. Thesis, McMaster University, Hamilton, Ontario, 213 pp.

Ainsworth, R.B., 1992. Sedimentology and sequence stratigraphy of the Upper Cretaceous, Bearpaw-Horseshoe Canyon transition, Drumheller, Alberta. American Association of Petroleum Geologists Annual Convention, Calgary, Field Trip Guidebook 7, 118 pp.

Ainsworth, R.B., 1994. Marginal marine sedimentology and high resolution sequence analysis; Bearpaw-Horseshoe Canyon transition, Drumheller, Alberta. Bulletin of Canadian Petroleum Geology 42,1, 26-54.

Ainsworth, R. B., 2005. Sequence stratigraphic-based analysis of reservoir connectivity: influence of depositional architecture - a case study from a marginal marine depositional setting. Petroleum Geoscience 11, 257-276.

Aitken, J.D., 1978. Revised model for depositional Grand Cycles, Cambrian of the southern Rocky Mountains, Canada. Can. Pet. Geol. Bull. 26, 515-542.

Allen, J.R. L., 1974. Studies in fluviatile sedimentation: implications of pedogenic carbonate units, Lower Old Red Sandstone, Anglo-Welsh outcrop: Geological Journal 9, 181-208.

Allen, G.P., Posamentier, H.W., 1993. Sequence stratigraphy and facies model of an incised valley fill: the Gironde estuary, France. Journal of Sedimentary Petrology 63,3, 378-391.

Anderson, R. Y., Dean, W.E., Kirkland, D. W., Snider, H.I., 1972. Permian Castile varved evaporite sequence, west Texas and New Mexico. Bull. Geol. Soc. Am. 83, 59-86.

Atrops, F., 1982. La sous-famille des Ataxioceratinae (Ammonitina) dans le Kimméridgien inférieur du Sud-Est de la France. Systématique, évolution, chronostratigraphie des genres Orthosphinctes et Ataxioceras. Doc. Lab. Géol. Lyon 83, 463 pp.

Bachtel, S.L., Dorobek, S.L., 1994. Mississippian carbonate platform profiles and preliminary sequence stratigraphic interpretation, San Andres and Sacramento Mountains, south-central New Mexico. In: Garber, R. A., Keller, D.R. (eds.), Field Guide to the Paleozoic Section of the San Andres Mountains: Midland, TX, Permian Basin Section - SEPM Publication 94-35, p.47-59.

Bachtel, S.L., Raatz, W. D., Rankey, E.C., 2000a. Shelf to basin variation in character of high-frequency sequences due to high-amplitude relative change in sea level: examples from the Pennsylvanian Orogrande Basin, New Mexico [abs.]. In: Ahr, W.M., Harris, P.M., Morgan, W. A., Somerville, I. D., Stanton, R. J., Jr. (eds.), PermoCarboniferous Carbonate Platforms and Reefs - SEPMIAS Research and Field Conference, Programs and Ab- 
stracts Volume: Tulsa, OK, SEPM (Society for Sedimentary Geology), p. 23.

Bachtel, S.L., Rankey, E.C., Kaufman, J., 2000b. Field guide for Pennsylvanian Holder Formation, Sacramento Mountains, NM: sequence development in mixed carbonate-siliciclastic strata during global icehouse climatic periods. In: Stanton, R.J., Jr. (ed.), Field Guide to the Carboniferous Geology of the Sacramento Mountains, New Mexico: Platforms and Mounds of the Lake Valley and Holder Formations: Tulsa, OK, SEPM (Society for Sedimentary Geology) and International Association of Sedimentologists Field Guide, p. 1-58.

Bard, B., Hamelin, R.G., Fairbanks, R., 1990. U-Th obtained by mass spectrometry in corals from Barbados: sea level during the past 130.000 years. Nature 346, 456458.

Bartek, L. R., Vail, P. R., Anderson, J. B., Emmet, P. A., Wu, S., 1991. Effect of Cenozoic ice sheet fluctuations in Antarctica on the stratigraphic signature of the Neogene. Journal of Geophysical Research 96, 6753-6778.

Bartek, L.R., Andersen, J.L.R., Oneacre, T. A., 1997. Substrate control on distribution of subglacial and glaciomarine seismic facies based on stochastic models of glacial seismic facies deposition on the Ross Sea continental margin, Antarctica. Marine Geology 143, 223-262.

Berger, A., Loutre, M.F., Dehant, V., 1989. Astronomical frequencies for pre-Quaternary palaeoclimate studies. Terra Nova 1, 474-479.

Best, J.L., Ashworth, P. J., 1997. Scour in large braided rivers and the recognition of sequence stratigraphic boundaries. Nature 387, 275-277.

Bhattacharya, J.P., 1993. The expression and interpretation of marine flooding surfaces and erosional surfaces in core; examples from the Upper Cretaceous Dunvegan Formation in the Alberta foreland basin. In: Summerhayes, C.P., Posamentier, H. W. (eds.), Sequence stratigraphy and facies associations. International Association of Sedimentologists Special Publication 18, 125-160.

Bhattacharya, J.P., Willis, B. J., 2001. Lowstand deltas in the Frontier Formation, Powder River Basin, Wyoming: Implications for sequence stratigraphic models. American Association of Petroleum Geologists Bulletin 85, 261-294.

Blackwelder, E., 1909. The valuation of unconformities. Journal of Geology 17, 289-299.

Blair, T.C., Bilodeau, W.L., 1988. Development of tectonic cyclothems in rift, pull-apart, and foreland basins: sedimentary response to episodic tectonism. Geology $\mathbf{1 6}$, 517-520.

Blum, M.D., 1990. Climatic and eustatic controls on Gulf coastal plain fluvial sedimentation: an example from the Late Quaternary of the Colorado River, Texas. In: Armentrout, J.M., Perkins, B.F. (eds.), Sequence Stratigraphy as an Exploration Tool, Concepts and Practices in the Gulf Coast. SEPM (Society of Economic Palaeontologists and Mineralogists) Gulf Coast Section, Eleventh Annual Research Conference, Program with Abstracts, p. 71-83.
Blum, M.D., 1991. Systematic controls of genesis and architecture of alluvial sequences: a Late Quaternary example. In: Leckie, D.A., Posamentier, H.W., Lovell, R.W. (eds.), NUNA Conference on High-Resolution Sequence Stratigraphy. Program with Abstracts, p.7-8.

Blum, M.D., 1994. Genesis and architecture of incised valley fill sequences: a Late Quaternary example from the Colorado River, Gulf Coastal Plain of Texas. In: Weimer, P., Posamentier, H.W. (eds.), Siliciclastic sequence stratigraphy: recent developments and applications. American Association of Petroleum Geologists Memoir 58, 259-283.

Blum, M.D., Price, D.M., 1998. Quaternary alluvial plain construction in response to glacio-eustatic and climatic controls, Texas Gulf coastal plain. In: Shanley, K.W., McCabe, P.J. (eds.), Relative Role of Eustasy, Climate, and Tectonism in Continental Rocks. SEPM (Society for Sedimentary Geology) Special Publication 59, 31-48.

Blum, M.D., Törnqvist, T.E., 2000. Fluvial responses to climate and sea-level change: a review and look forward. Sedimentology 47, 2-48.

Bohacs, K., Suter, J., 1997. Sequence stratigraphic distribution of coaly rocks: fundamental controls and paralic examples. American Association of Petroleum Geologists Bulletin 81, 1612-1639.

Booler, J.P., Tucker, M.E., 2002. Distribution and geometry of facies and early diagenesis: the key to accommodation space variation and sequence stratigraphy: Upper Cretaceous Congost Carbonate Platform, Spanish Pyrenees. Sedimentary Geology, 146, 225-247.

Borer, J.M., Harris, P. M., 1991. Lithofacies and cyclicity of the Yates Formation, Permian Basin: Implications for reservoir heterogeneity. American Association of Petroleum Geologists Bulletin 75, 726-779.

Boulila, S., Galbrun, B., Hinnov, L.A., Collin, P.-Y., 2008. Orbital calibration of the Early Kimmeridgian (southeastern France): implications for geochronology and sequence stratigraphy. Terra Nova 20, 455-462.

Bover-Arnal, T., Salas, R., Moreno-Bedmar, J.A., Bitzer, K., 2009. Sequence stratigraphy and architecture of a late Early-Middle Aptian carbonate platform succession from the western Maestrat Basin (Iberian Chain, Spain). Sedimentary Geology 219, 280-301.

Boyd, R., Diessel, C.F.K., Wadsworth, J., Leckie, D., Zaitlin, B.A., 2000. Organization of non marine stratigraphy. In: Boyd, R., Diessel, C. F. K., Francis, S. (eds.), Advances in the study of the Sydney Basin. Proceedings of the $34^{\text {th }}$ Newcastle Symposium, University of Newcastle, Callaghan, New South Wales, Australia, 1-14.

Brachert, T.C., Forst, M.H., Pais, J. J., Legoinha, P., Reijmer, J. J. G., 2003. Lowstand carbonates, highstand sandstones? Sedimentary Geology $\mathbf{1 5 5}, 1-12$.

Braga, J.C., Martin, J.M., Alcala, B., 1990. Coral reefs in coarse-terrigenous sedimentary environments, Upper Tortonian, Granada Basin, southern Spain. Sedimentary Geology 66, 135-150.

Brami, T.R., Pirmez, C., Archie, C., Heeralal, S., Holman, K.L., 2000. Late Pleistocene deep-water stratigraphy and depositional processes, offshore Trinidad and Tobago. In: 
Weimer, P., Slatt, R. M., Coleman, J., Rosen, N.C., Nelson, H., Bouma, A.H., Styzen, M.J., Lawrence, D.T. (eds.), Deep-water Reservoirs of the World. Gulf Coast Society of the Society of Economic Paleontologists and Mineralogists Foundation, 20th Annual Research Conference, p. 104-115.

Brown, L.F., Jr., Fisher, W.L., 1977. Seismic stratigraphic interpretation of depositional systems: examples from Brazilian rift and pull apart basins. In: Payton, C.E. (ed.), Seismic Stratigraphy - Applications to Hydrocarbon Exploration. American Association of Petroleum Geologists Memoir 26, 213-248.

Burchette, T.P., Wright, V.P., 1992. Carbonate ramp depositional systems. Sedimentary Geology 79, 3-57.

Cantalamessa, G., Di Celma, C., Ragaini, L., 2005. Sequence stratigraphy of the middle unit of the Jama Formation (Early Pleistocene, Ecuador): insights from integrated sedimentologic, taphonomic and paleoecologic analysis of molluscan shell concentrations. Palaeogeography, Palaeoclimatology and Palaeoecology 216, 1-25.

Cantalamessa, G., Di Celma, C., Ragaini, L., Valleri, G., Landini, W., 2007. Sedimentology and high-resolution sequence stratigraphy of the late Middle to Late Miocene Angostura Formation (western Borbon Basin, northwestern Ecuador). Journal of the Geological Society, London 164, 653-665.

Carter, R.M., Abbott, S.T., Fulthorpe, C.S., Haywick, D.W., Henderson, R.A., 1991. Application of global sea-level and sequence-stratigraphic models in southern hemisphere Neogene strata. In: Macdonald, D. I. M. (ed.), Sedimentation, Tectonics and Eustasy: Sea-Level Changes at Active Margins. International Association of Sedimentologists, Special Publication 12, 41-65.

Carter, R.M., Fulthorpe, C.S., Naish, T.R., 1998. Sequence concepts at seismic and outcrop scale: the distinction between physical and conceptual stratigraphic surfaces. Sedimentary Geology 122, 165-179.

Catuneanu, O., 2006. Principles of Sequence Stratigraphy. Elsevier, Amsterdam, 375 pp.

Catuneanu, O., Martins-Neto, M. A., Eriksson, P.G., 2005. Precambrian sequence stratigraphy. Sedimentary Geology 176, 67-95.

Catuneanu, O., Hancox, P. J., Cairncross, B., Rubidge, B. S., 2002. Foredeep submarine fans and forebulge deltas: orogenic off-loading in the underfilled Karoo Basin. Journal of African Earth Sciences 33, 489-502.

Catuneanu, O., Abreu, V., Bhattacharya, J.P., Blum, M.D., Dalrymple, R.W., Eriksson, P.G., Fielding, C.R., Fisher, W.L., Galloway, W.E., Gibling, M.R., Giles, K. A., Holbrook, J. M., Jordan, R., Kendall, C. G. St.C., Macurda, B., Martinsen, O.J., Miall, A.D., Neal, J.E., Nummedal, D., Pomar, L., Posamentier, H.W., Pratt, B.R., Sarg, J.F., Shanley, K.W., Steel, R.J., Strasser, A., Tucker, M.E., Winker, C., 2009. Towards the standardization of sequence stratigraphy. Earth-Science Reviews, vol. 92, 1-33.

Catuneanu, O., Bhattacharya, J.P., Blum, M.D., Dalrymple, R.W., Eriksson, P.G., Fielding, C.R., Fisher, W.L., Galloway, W.E., Gianolla, P., Gibling, M.R., Giles, K.A.,
Holbrook, J. M., Jordan, R., Kendall, C. G. St. C., Macurda, B., Martinsen, O.J., Miall, A.D., Nummedal, D., Posamentier, H.W., Pratt, B.R., Shanley, K.W., Steel, R.J., Strasser, A., Tucker, M.E., 2010. Sequence stratigraphy: common ground after three decades of development. First Break 28, 21-34.

Cecca, F., Vrielynck, B., Lavoyer, T., Gaget, H., 2005. Changes in the ammonite taxonomical diversity gradient during the late Jurassic - early Cretaceous. J. Biogeogr. 32, 535-547.

Chen, D., Tucker, M.E., 2003. The Frasnian-Famennian mass extinction: insights from high-resolution sequence stratigraphy and cyclostratigraphy in South China. Palaeogeography, Palaeoclimatology, Palaeoecology 193, 87-111.

Christie-Blick, N., 1991. Onlap, offlap, and the origin of unconformity-bounded depositional sequences. Marine Geology 97, 35-56.

Clari, P. A., Dela Pierre, F., Martire, L., 1995. Discontinuities in carbonate successions: identification, interpretation and classification of some Italian examples. Sedimentary Geology 100, 97-121.

Colombié, C., 2002. Sédimentologie, stratigraphie séquentielle et cyclostratigraphie du Kimméridgien du Jura suisse et du Bassin vocontien (France): relations plateforme - bassin et facteurs déterminants. GeoFocus 4, Fribourg, 198 pp.

Colombié, C., Rameil, N., 2006. Tethyan-to-boreal correlation in the Kimmeridgian using high-resolution sequence stratigraphy (Vocontian Basin, Swiss Jura, Boulonnais, Dorset). International Journal Earth Sciences 96, 567591.

Colombié, C., Strasser, A., 2003. Depositional sequences in the Kimmeridgian of the Vocontian Basin (France) controlled by carbonate export from shallow-water platforms. Geobios 36, 675-683.

Colombié, C., Strasser, A., 2005. Facies, cycles, and controls on the evolution of a keep-up carbonate platform (Kimmeridgian, Swiss Jura). Sedimentology 52, 12071227.

Covault, J.A., Normark, W.R., Romans, B.W., Graham, S. A., 2007. Highstand fans in the California borderland: the overlooked deep-water depositional systems. Geology 35, 783-786.

Cowan, C.A., James, N.P., 1993. The interactions of sealevel change, terrigenous-sediment influx and carbonate productivity as controls on Upper Cambrian Grand Cycles of western Newfoundland, Canada. Bulletin Geological Society of America 105, 1576-1590.

Currie, B.S., 1997, Sequence stratigraphy of nonmarine Jurassic-Cretaceous rocks, central Cordilleran forelandbasin system. Bulletin Geological Society of America 109, 1206-1222.

Dalrymple, R.W., Boyd, R., Zaitlin, B. A., eds., 1994. Incised-valley systems: origin and sedimentary sequences. Society of Economic Paleontologists and Mineralogists Special Publication 51, $391 \mathrm{pp}$.

D’Argenio, B., Ferreri, V., Amodio, S., Pelosi, N., 1997. Hierarchy of high-frequency orbital cycles in Cretaceous 
carbonate platform strata. Sedimentary Geology 113,3-4, 169-193.

Davies, P.J., Symonds, P.A., Feary, D. A., Pigram, C.J., 1989. The evolution of the carbonate platforms of northeast Australia. - In: Crevello, P. G., Wilson, J.J., Sarg, J.F. \& Read, J.F. (eds.): Carbonate Platform and Basin Development. Soc. Econ. Petrol. Min. (Society for Sedimentary Geology) Spec. Publ. 44, 233-257.

Davydov, V., Crowley, J.L., Schmitz, M.D. \& Poletaev, V., 2010. High-precision U-Pb zircon age calibration of the global Carboniferous time-scale and Milankovitch band cyclicity in the Donets Basin, eastern Ukraine. Geochem. Geophys. Geosyst. 11: online at A.G.U.

De Rafélis, M., Emmanuel, L., Renard, M., Atrops, F., Jan du Chene, R., 2001. Geochemical characterization (Mn content) of third order eustatic sequences in Upper Jurassic pelagic carbonates of the Vocontian Trough (SE France). Eclogae Geol. Helv. 94, 145-152.

Dercourt, J., Gaetani, M., Vrielynck, B., Barrier, E., BijuDuval, B., Brunet, M.F., Cadet, J.P., Crasquin, S., Sandulescu, M., 2000. Atlas Peri-Tethys; Palaeogeographical maps. Paris.

Di Celma, C., Cantalamessa, G., 2007. Sedimentology and high-frequency sequence stratigraphy of a forearc extensional basin: the Miocene Caleta Herradura Formation, Mejillones Peninsula, northern Chile. Sedimentary Geology 198, 29-52.

Drummond, C.N., Wilkinson, B.H., 1996. Stratal thickness frequencies and the prevalence of orderedness in stratigraphic sequences. Journal of Geology 104, 1-18.

Eberli, G.P., Harris, P.M., Grammer, G. M., Cruz, F.E.G., 2005. Field Guide to the CSL-AAPG Seminar on sequence Stratigraphy and Reservoir Distribution in a Modern Carbonate Platform, Bahamas: University of Miami Comparative Sedimentology Laboratory Sedimenta CD Series No.3.

Eberli, G.P., Anselmetti, F.S., Betzler, C., Van Konijnenburg, J.-H., Bernoulli, D., 2004. Carbonate platform to basin transition on seismic data and in outcrop - Great Bahama Bank and the Maiella platform, Italy. In: Eberli, G.P., Massaferro, J.L., Sarg, J.F. (eds.) Seismic Imaging of Carbonate Reservoirs and Systems, AAPG Memoir 81, 207-250.

Edwards, M.B., 1991. Stratigraphic analysis and reservoir prediction in the Eocene Yegua and Cook Mountain Formations of Texas and Louisiana. In: Armentrout, J.M., Perkins, B.F. (eds.), Sequence Stratigraphy as Exploration Tool, Concepts and Practices in the Gulf Coast: Gulf Coast Section, SEPM Foundation Eleventh Annual Research Conference, p. 141-160.

Elrick, M., Read, J.F., 1991. Cyclic ramp-to-basin carbonate deposits, Lower Mississippian, Wyoming and Montana: a combined field and computer modelling study. Journal of Sed. Petrol. 61, 1194-1224.

Embry, A.F., 1995. Sequence boundaries and sequence hierarchies: problems and proposals. In: Steel, R. J., Felt, V.L., Johannessen, E.P., Mathieu, C. (eds.), Sequence stratigraphy on the Northwest European Margin. Nor- wegian Petroleum Society (NPF), Special Publication 5, $1-11$.

Embry, A.F., Johannessen, E. P., 1992. T-R sequence stratigraphy, facies analysis and reservoir distribution in the uppermost Triassic-Lower Jurassic succession, western Sverdrup Basin, Arctic Canada. In: Vorren, T. O., Bergsager, E., Dahl-Stamnes, O. A., Holter, E., Johansen, B., Lie, E., Lund, T.B. (Eds.), Arctic Geology and Petroleum Potential, vol. 2 (Special Publication). Norwegian Petroleum Society (NPF), pp. 121-146.

Emery, D., Myers, K.J., 1996. Sequence Stratigraphy. Oxford, U.K., Blackwell, 297 pp.

Fang, Q., 2000. Biostratigraphic and sequence stratigraphic analysis of the Yegua Formation, Houston salt embayment, northern Gulf of Mexico. University of Texas at Austin Ph. D. Dissertation, 284 pp.

Fiduk, J.C., Weimer, P., Trudgill, B.D., Rowan, M. G., Gale, P.E., Phair, R.L., Korn, B.E., Roberts, G.R., Gafford, W.T., Lowe, R.S., Queffelec, T.A., 1999. The Perdido Fold Belt, Northwestern Deep Gulf of Mexico, Part 2: Seismic Stratigraphy and Petroleum Systems. American Association of Petroleum Geologists Bulletin 83,4, 578612.

Fielding, C.R., Naish, T.R., Woolfe, K.J., Lavelle, M.A., 2000. Facies analysis and sequence stratigraphy of CRP-2/2A, Victoria Land Basin, Antarctica. Terra Antartica 7, 323-338.

Fielding, C.R., Naish, T.R., Woolfe, K. J., 2001. Facies architecture of the CRP-3 drillhole, Victoria Land Basin, Antarctica. Terra Antartica 8, 217-224.

Fielding, C.R., Bann, K.L., MacEachern, J.A., Tye, S.C., Jones, B.G., 2006. Cyclicity in the nearshore marine to coastal, Lower Permian, Pebbley Beach Formation, southern Sydney Basin, Australia: a record of relative sea-level fluctuations at the close of the Late Palaeozoic Gondwanan ice age. Sedimentology 53, 435-463.

Fielding, C.R., Frank, T. D., Birgenheier, L.P., Rygel, M.C., Jones, A. T., Roberts, J., 2008. Stratigraphic record and facies associations of the late Paleozoic ice age in eastern Australia (New South Wales and Queensland). In: Fielding, C.R., Frank, T.D., Isbell, J.L. (eds.), Resolving the Late Paleozoic Ice Age in Time and Space. Geological Society of America, Special Paper 441, 41-57.

Fischer, A.G., 1964. The Lofer cyclothems of the Alpine Triassic. In: Merriam, D.F. (ed.), Symposium on Cyclic Sedimentation: Kansas Geological Survey, Bulletin 169, 107-149.

Frazier, D.E., 1974. Depositional episodes: their relationship to the Quaternary stratigraphic framework in the northwestern portion of the Gulf Basin. University of Texas at Austin, Bureau of Economic Geology Geological Circular 71-1, 28 pp.

French, V.L., Kerans, C., 2004. Accommodation-controlled systems-tract - specific facies partitioning and resulting geometric development of reservoir grainstone ramp-crest shoal bodies. In: Grammer, G. M., Harris, P.M., Eberli, G.P. (eds.), Integration of outcrop and modern analogs in reservoir modeling. AAPG Memoir 80, 171-190. 
Galloway, W.E., 1989. Genetic stratigraphic sequences in basin analysis, I. Architecture and genesis of floodingsurface bounded depositional units. American Association of Petroleum Geologists Bulletin 73, 125-142.

Galloway, W.E., 2001. The many faces of submarine erosion: theory meets reality in selection of sequence boundaries. A.A.P.G. Hedberg Research Conference on "Sequence Stratigraphic and Allostratigraphic Principles and Concepts", Dallas, August 26-29, Program and Abstracts Volume, p. 28-29.

Galloway, W.E., 2004. Accommodation and the sequence stratigraphic paradigm. Reservoir, Canadian Society of Petroleum Geologists 31,5, 9-10.

Galloway, W.E., 2008. Depositional evolution of the Gulf of Mexico Sedimentary Basin. In: Miall, A.D. (ed.), The Sedimentary Basins of the United States and Canada: Sedimentary Basins of the World, v.5, K.J.Hsu, Series Editor, Elsevier Science Amsterdam, p. 505-550.

Galloway, W.E., Whiteaker, T., Ganey-Curry, P., 2011, in press. History of Cenozoic North American drainage basin evolution, sediment yield, and accumulation in the Gulf of Mexico Basin. Geosphere 7.

Glumac, B., Walker, K. R., 2000. Carbonate deposition and sequence stratigraphy of the terminal Cambrian grand cycle in the southern Appalachians. Jour. of Sed. Res. 70, 952-963.

Goldhammer, R. K., Dunn, P. A., Hardie, L. A., 1990. Depositional cycles, composite sea-level changes, cycle stacking patterns, and the hierarchy of stratigraphic forcing: Examples from Alpine Triassic platform carbonates. Geological Society of America Bulletin 102, 535-562.

Goldhammer, R. K., Oswald, E. J., Dunn, P. A., 1994. Highfrequency glacio-eustatic cyclicity in the Middle Pennsylvania of the Paradox Basin: an evaluation of Milankovitch forcing. In: De Boer, P.L., Smith, D. G. (eds.), Orbital Forcing and Cyclic Sequences. IAS Spec. Publ. 19, 243-283.

Grammer, G. M., Ritter, A.L., 2008. Phylloid algal mounds in the Paradox Basin U.S.A. - an alternative to the in situ constructional growth model? In: Swart, P.K., McKenzie, J., Eberli, G.P. (eds.), Perspectives in Sedimentary Geology: A Tribute to the Career of Robert Nathan Ginsburg. International Association of Sedimentologists Special Publication 40, 239-254.

Gygi, R.A., 2000. Integrated stratigraphy of the Oxfordian and Kimmeridgian (Late Jurassic) in northern Switzerland and adjacent southern Germany. Mem. Swiss Acad. Sci. 104, 152 pp.

Hampson, G.J., Storms, J.E.A., 2003. Geomorphological and sequence stratigraphic variability in wave-dominated, shoreface-shelf parasequences. Sedimentology 50, 667-701.

Handford, R., Loucks, R. G., 1993. Carbonate depositional sequences and systems tracts: responses of carbonate platforms to relative sea-level change. In: Loucks, R.G., Sarg, R. (eds.), Carbonate sequence stratigraphy: recent advances and applications: American Association of Petroleum Geologists Memoir 57, 3-41.
Haq, B.U., Hardenbol, J., Vail, P.R., 1987. Chronology of fluctuating sea levels since the Triassic (250 million years ago to present). Science 235, 1156-1166.

Hardenbol, J., Thierry, J., Farley, M. B., Jacquin, T., De Graciansky, P.-C., Vail, P.R., 1998. Jurassic sequence chronostratigraphy. SEPM Spec. Publ. 60, chart.

Hart, B.S., Plint, A. G., 1993. Origin of an erosion surface in shoreface sandstones of the Kakwa Member (Upper Cretaceous Cardium Formation, Canada): importance for reconstruction of stratal geometry and depositional history. In: Posamentier, H.W., Summerhayes, C.P., Haq, B.U., Allen, G.P. (eds.), Sequence Stratigraphy and Facies Associations. International Association of Sedimentologists, Special Publication 18, 451-467.

Helland-Hansen, W., Gjelberg, J.G., 1994. Conceptual basis and variability in sequence stratigraphy: a different perspective. Sedimentary Geology $\mathbf{9 2}, 31-52$.

Helland-Hansen, W., Hampson, G. J., 2009. Trajectory analysis: concepts and applications. Basin Research 21, 454-483.

Helland-Hansen, W., Martinsen, O.J., 1996. Shoreline trajectories and sequences: description of variable depositional-dip scenarios. Journal of Sedimentary Research 66, 4, 670-688.

Hinnov, L.A., Ogg, J.G., 2007. Cyclostratigraphy and the astronomical time scale. Stratigraphy 4, 239-251.

Hochuli, P. A., Menegatti, A. P., Weissert, H., Riva, A., Erba, E., Premoli Silva, I., 1999. Episodes of high productivity and cooling in the early Aptian Alpine Tethys. Geology 27, 657-660.

Hodgson, D. M., Flint, S. S., Hodgetts, D., Drinkwater, N. J., Johannessen, E.P., Luthi, S. M., 2006. Stratigraphic evolution of fine-grained submarine fan systems, Tanqua depocenter, Karoo Basin, South Africa. Journal of Sedimentary Research 76, 20-40.

Holbrook, J., Scott, R.W., Oboh-Ikuenobe, F.E., 2006. Base-level buffers and buttresses: a model for upstream versus downstream control on fluvial geometry and architecture within sequences. Journal of Sedimentary Research 76, 162-174.

Hunt, D., Tucker, M.E., 1992. Stranded parasequences and the forced regressive wedge systems tract: deposition during base-level fall. Sedimentary Geology 81, 1-9.

Hunt, D., Tucker, M.E., 1995. Stranded parasequences and the forced regressive wedge systems tract: deposition during base-level fall - reply. Sedimentary Geology 95, 147-160.

Ineson, J.R., Surlyk, F., 2000. Carbonate mega-breccias in a sequence stratigraphic context: evidence from the Cambrian of North Greenland. In: Hunt, D., Gawthorpe, R.L. (eds.), Sedimentary Responses to Forced Regression. Geol. Soc. of London Spec. Publ. 172, 47-68.

Jennette, D.C., Pryor, W.A., 1993. Cyclic alternation of proximal and distal storm facies: Kope, Fairview Formations (Upper Ordovician), Ohio and Kentucky. Jour. of Sed. Petrol. 63, 183-203.

Jervey, M.T., 1988. Quantitative geological modeling of siliciclastic rock sequences and their seismic expression. 
In: Wilgus, C.K., Hastings, B.S., Kendall, C.G.St.C., Posamentier, H.W., Ross, C.A., Van Wagoner, J.C. (eds.), Sea Level Changes - An Integrated Approach. Society of Economic Paleontologists and Mineralogists (SEPM) Special Publication 42, 47-69.

Johnson, J.G., Murphy, M.A., 1984. Time-rock model for Siluro-Devonian continental shelf, western United States. Geological Society of America Bulletin 95, 1349-1359.

Johnson, J.G., Klapper, G., Sandberg, C. A., 1985. Devonian eustatic fluctuations in Euramerica. Geological Society of America Bulletin 96, 567-587.

Jones., B., Desrochers, A., 1992. Shallow platform carbonates. In: Walker, R. G., James, N.P. (eds.), Facies Models: Response to Sea Level Change, p. 277-302.

Kendall, C.G.St.C., Schlager, W., 1981. Carbonates and relative changes in sea level. Marine Geol. 44, 181-212.

Kerans, C., 2002. Styles of Rudist Buildup Development along the Northern Margin of the Maverick Basin, Pecos River Canyon, Southwest Texas. Gulf Coast Association of Geological Societies Transactions, Volume 52, 501516.

Kerans, C., Zahm, L., Kempter, K., Ward, W. B., 1997a. Sequence stratigraphy of reservoir analog Cretaceous (Albian) carbonates, Pecos River, West Texas. The University of Texas at Austin, Bureau of Economic Geology Field Trip Guidebook, 85 pp.

Kerans, C., Fitchen, W., Zahm, L., Ward, B., Osleger, D., Barnaby, R., Jennings, J., 1997b. Carbonate reservoir heterogeneity styles within a sequence stratigraphic framework: Albian (Cretaceous), Pecos River Canyon. The University of Texas at Austin, Bureau of Economic Geology, RCRL Laboratory Field Trip Guidebook, 130 pp.

Kerr, D., Ye, L., Bahar, A., Kelkar, B.G., Montgomery, S., 1999. Glenn Pool field, Oklahoma: a case of improved prediction from a mature reservoir. American Association of Petroleum Geologists Bulletin 83,1, 1-18.

Kidwell, S.M., 1997. Anatomy of extremely thin marine sequences landward of a passive margin hinge-zone: Neogene Calvert Cliffs succession, Maryland, USA. Journal of Sedimentary Research 67, 322-340.

Krapez, B., 1996. Sequence-stratigraphic concepts applied to the identification of basin-filling rhythms in Precambrian successions. Australian Journal of Earth Sciences 43, 355-380.

Krapez,B., 1997. Sequence-stratigraphic concepts applied to the identification of depositional basins and global tectonic cycles. Australian Journal of Earth Sciences 44, 1-36.

Langreis, C.G., Krijgsman, W., Muttoni, G., Menning, M., 2010. Magnetostratigraphy - concepts, definitions, and applications. Newsletter on Stratigraphy 43, 207-233.

Larcombe, P., Costen, A., Woolfe, K. J., 2001. The hydrodynamic and sedimentary setting of nearshore coral reefs, central Great Barrier Reef shelf, Australia, Paluma Shoals, a case study. Sedimentology 48, 811-835.

Larue, D.K., Sprague, A.R., Patterson, P.E., Van Wagoner, J.C., 1995. Multi-Storey Sandstone Bodies, Sequence Stratigraphy, and Fluvial Reservoir Connectivity. Bulletin AAPG (Abstract), AAPG Annual Meeting 79, 13, 54.
Leckie, D. A., 1994. Canterbury Plains, New Zealand - Implications for sequence stratigraphic models. American Association of Petroleum Geologists Bulletin 78, 1240-1256.

Lenoble, J.L., Canerot, J., 1993. Sequence stratigraphy of the Clansayesian (uppermost Aptian) formations in the western Pyrenees (France). In: Posamentier, H.W., Summerhayes, C.P., Haq, B.U. \& Allen, G.P. (eds.), Sequence Stratigraphy and Facies Associations. Special Publication International Association of Sedimentologists 18, 283294, Blackwell Scientific Publications, Oxford.

Levorsen, A.L., 1943. Discovery thinking. American Association of Petroleum Geologists Bulletin 27, 887-928.

Loucks, R.G., Kerans, C., Marhx, A., 2006. Origin and Organization of Mass-Transported Carbonate Debris in the Lower Cretaceous (Albian) Tamabra Formation, Poza Rica Field Area, Mexico. SEPM Research Symposium: The Significance of Mass Transport Deposits in Deepwater Environments II, AAPG Annual Convention, April 912, 2006 Technical Program.

Loutit, T.S., Hardenbol, J., Vail, P. R., Baum, G.R., 1988. Condensed sections: the key to age-dating and correlation of continental margin sequences. In: Wilgus, C.K., Hastings, B.S., Kendall, C. G. St. C., Posamentier, H. W., Ross, C.A., Van Wagoner, J.C. (eds.), Sea Level Changes - An Integrated Approach. SEPM Special Publication 42, 183-213.

Lukasik, J.J., James, N.P., 2003. Deepening-Upward Subtidal Cycles, Murray Basin, South Australia. Journal of Sedimentary Research 73,5, 653-671.

MacEachern, J.A., Raychaudhuri, I., Pemberton, S.G., 1992. Stratigraphic applications of the Glossifungites ichnofacies: delineating discontinuities in the rock record. In: Pemberton, S.G. (ed.), Applications of Ichnology to Petroleum Exploration. Society of Economic Paleontologists and Mineralogists, Core Workshop Notes 17, 169198.

MacEachern, J.A., Zaitlin, B.A., Pemberton, S.G., 1998. High resolution sequence stratigraphy of early transgressive incised shoreface and early transgressive valley/embayment deposits of the Viking Formation, Joffre Field, Alberta, Canada. American Association of Petroleum Geologists Bulletin 82, 729-756.

MacEachern, J. A., Zaitlin, B. A., Pemberton, S. G., 1999. A sharp-based sandstone of the Viking Formation, Joffre field, Alberta, Canada: criteria for recognition of transgressively incised shoreface complexes. Journal of Sedimentary Research 69,4, 876-892.

MacNeil, A. J., Jones, B., 2006. Sequence stratigraphy of a Late Devonian ramp-situated reef system in the Western Canada Sedimentary Basin: dynamic responses to sealevel change and regressive reef development. Sedimentology 53, 321-359.

Manley, L., Flood, R.D., 1998. Cyclic sediment deposition within Amazon deep-sea fan. AAPG Bulletin 72, 912-925.

Martin, J., Paola, C., Abreu, V., Neal, J., Sheets, B., 2009. Sequence stratigraphy of experimental strata under known conditions of differential subsidence and variable base level. AAPG Bull. 93, 503-533. 
Martinsen, R.S., Christensen, G., 1992. A stratigraphic and environmental study of the Almond Formation, Mesaverde Group, Greater Green River Basin, Wyoming. Wyoming Geological Association Guidebook, Fortythird Field Conference, p. 171-190.

Masson, D.G., Canals, M., Alonso, B., Urgeles, R., Huhnerbach, V., 1998. The Canary debris flow; source area morphology and failure mechanisms. Sedimentology 45 , 411-432.

Mawson, M., Tucker, M.E., 2009. High-frequency cyclicity (millennial-scale and Milankovitch) in slope carbonates (Zechstein) Permian, NE England. Sedimentology 56, 1905-1936.

Meckel, L. D., III, 1993. Stratigraphy and sedimentology of the Eocene Yegua Formation, Texas Gulf Coast. M.A. Thesis, Univ. Texas at Austin, $112 \mathrm{pp}$.

Meckel, L.D., III, Galloway, W.E., 1996. Formation of high-frequency sequences and their bounding surfaces; case study of the Eocene Yegua Formation, Texas Gulf Coast. Sedimentary Geology 102, 155-187.

Mellere, D., Steel, R., 1995. Variability of lowstand wedges and their distinction from forced-regressive wedges in the Mesaverde Group, southeast Wyoming. Geology 23,9, 803-806.

Meng, X., Ge, M., Tucker, M.E., 1997. Sequence stratigraphy, sea-level changes and depositional systems in the Cambro-Ordovician of the North China carbonate platform. Sedimentary Geology 114, 189-223.

Menning, M., Alekseev, A.S., Chuvashov, B.I., Davydov, V.I., Devuyst, F.-X., Forke, H.C., Grunt, T. A., Hance, L., Heckel, P.H., Izokh, N.G., Jin, Y.-G., Jones, P.J., Kotlyar, G. V., Kozur, H.W., Nemyrovska, T.I., Schneider, J.W., Wang, X.-D., Weddige, K., Weyer, D., Work, D.M., 2006. Global time scale and regional stratigraphic reference scales of Central and West Europe, East Europe, Tethys, South China, and North America as used in the Devonian-CarboniferousPermian Correlation Chart 2003 (DCP 2003) Palaeogeography, Palaeoclimatology, Palaeoecology 240, 318-372.

Miall, A. D., 1988. Reservoir heterogeneities in fluvial sandstones: lessons from outcrop studies. American Association of Petroleum Geologists Bulletin 72, 682-697.

Miall, A. D., 1991. Stratigraphic sequences and their chronostratigraphic correlation. Journal of Sedimentary Petrology 61, 497-505.

Miall, A.D., 1995. Whither stratigraphy? Sedimentary Geology 100, 5-20.

Miall, A.D., 1996. The geology of fluvial deposits: sedimentary facies, basin analysis and petroleum geology. Springer-Verlag Inc., Heidelberg, 582 pp.

Miall, A. D., 1997. The Geology of Stratigraphic Sequences. Springer-Verlag, $433 \mathrm{pp}$.

Miall, A.D., 2010. The geology of stratigraphic sequences, second edition. Springer-Verlag, Berlin, 522 pp.

Miall, A.D., Arush, M., 2001a. Cryptic sequence boundaries in braided fluvial successions. Sedimentology 48(5), 971-985.

Miall, A.D., Arush, M., 2001b. The Castlegate Sandstone of the Book Cliffs, Utah: sequence stratigraphy, paleogeog- raphy, and tectonic controls. Journal of Sedimentary Research 71, 536-547.

Miall, A.D., Miall, C.E., 2001. Sequence stratigraphy as a scientific enterprise: the evolution and persistence of conflicting paradigms. Earth-Science Reviews 54, 321-348.

Miall, A.D., Catuneanu, O., Vakarelov, B., Post, R., 2008. The Western Interior Basin. In: Miall, A.D. (ed.), The Sedimentary Basins of the United States and Canada: Sedimentary basins of the World, v.5, K.J.Hsü, Series Editor, Elsevier Science, Amsterdam, p. 329-362.

Miller, D. J., Eriksson, K. A., 2000. Sequence stratigraphy of Upper Mississippian strata in the Central Appalachians: a record of glacio-eustasy and tectono-eustasy in a foreland basin setting. Am. Assoc. Petrol. Geol. Bull. 84, 210-233.

Mitchum, R.M., Jr., 1977. Seismic stratigraphy and global changes of sea level, part 11: glossary of terms used in seismic stratigraphy. In: Payton, C.E. (ed.), Seismic Stratigraphy - Applications to Hydrocarbon Exploration. American Association of Petroleum Geologists Memoir 26, 205-212.

Mitchum, R.M., Jr., Van Wagoner, J.C., 1991. High-frequency sequences and their stacking patterns: sequence stratigraphic evidence of high-frequency eustatic cycles. Sedimentary Geology 70, 131-160.

Mitchum, R.M., Jr., Vail, P.R., Thompson, S., III, 1977. Seismic stratigraphy and global changes of sea-level, part 2: the depositional sequence as a basic unit for stratigraphic analysis. In: Payton, C.E. (ed.), Seismic Stratigraphy - Applications to Hydrocarbon Exploration. American Association of Petroleum Geologists Memoir 26, 53-62.

Montañez, I. P., Osleger, D. A., 1993. Parasequence stacking patterns, third-order accommodation events, and sequence stratigraphy of Middle to Upper Cambrian platform carbonates, Bonanza King Formation, southern Great Basin. In: Loucks, R. G., Sarg, J.F. (eds.), Carbonate Sequence Stratigraphy. AAPG Mem. 57, 305-326.

Naish, T., Kamp, P. J.J., 1997. Foraminiferal depth palaeoecology of Late Pliocene shelf sequences and systems tracts, Wanganui Basin, New Zealand. Sedimentary Geology 110, 237-255.

Naish, T.R., Woolfe, K.J., Barrett, P.J., Wilson, G.S., Atkins, C., Bohaty, S.M., Bucker, C. J., Claps, M., Davey, F.J., Dunbar, G.B., Dunn, A.G., Fielding, C.R., Florindo, F., Hannah, M.J., Harwood, D.M., Henrys, S.A., Krissek, L.A., Lavelle, M.A., van der Meer, J., McIntosh, W.C., Niessen, F., Passchier, S., Powell, R.D., Roberts, A.P., Sagnotti, L., Scherer, R.P., Strong, C.P., Talarico, F., Verosub, K.L., Villa, G., Watkins, D.K., Webb, P.-N., Wonik, T., 2001. Orbitally induced oscillations in the East Antarctic ice sheet at the Oligocene/ Miocene boundary. Nature 413, 719-723.

Nio, S. D., Yang, C. S., 1991. Sea-level fluctuations and the geometric variability of tide-dominates sandbodies. Sedimentary Geology 70, 161-193.

Nummedal, D., 1992. The falling sea-level systems tract in ramp settings. In: SEPM Theme Meeting, Fort Collins, Colorado (abstracts), p. 50. 
Nummedal, D., Molenaar, C.M., 1995. Sequence stratigraphy of a ramp-setting strand plain succession: the Gallup Sandstone, New Mexico. In: Van Wagoner, J.C., Bertram, G.B. (eds.), Sequence Stratigraphy of Foreland Basin Deposits - Outcrop and Subsurface examples from the Cretaceous of North America. American Association of Petroleum Geologists Memoir 64, 277-310.

Nummedal, D., Swift, D. J.P., 1987. Transgressive stratigraphy at sequence-bounding unconformities: some principles derived from Holocene and Cretaceous examples. In: Nummedal, D., Pilkey, O.H., Howard, J. D. (eds.) Sealevel fluctuation and coastal evolution. Society of Economic Paleontologists and Mineralogists (SEPM) Special Publication 41, 241-260.

Nummedal, D., Riley, G.W., Templet, P.L., 1993. Highresolution sequence architecture: a chronostratigraphic model based on equilibrium profile studies. In: Posamentier, H.W., Summerhayes, C.P., Haq, B. U., Allen, G.P (eds.), Sequence Stratigraphy and Facies Associations. International Association of Sedimentologists Special Publication 18, 55-68.

Olsen, T., Steel, R.J., Høgseth, K., Skar, T., Røe, S.-L., 1995. Sequential architecture in a fluvial succession: sequence stratigraphy in the Upper Cretaceous Mesaverde Group, Price Canyon, Utah. Journal of Sedimentary Research B65, 265-280.

Osleger, D., Read, J.F., 1991. Relation of eustasy to stacking patterns of meter-scale carbonate cycles, Late Cambrian, USA. Journal of Sedimentary Petrology 61, 1225-1252.

Paleo-Data, 2009. Biostratigraphic Chart, Gulf Basin U.S.A., Paleogene: Version 0906, http://www.paleodata.com/downloads.html.

Pemberton, S.G., MacEachern, J.A., 1995. The sequence stratigraphic significance of trace fossils: examples from the Cretaceous foreland basin of Alberta, Canada. In: Van Wagoner, J.C., Bertram, G. (eds.), Sequence stratigraphy of foreland basin deposits - outcrop and subsurface examples from the Cretaceous of North America. American Association of Petroleum Geologists Memoir 64, 429-475.

Peryt, T.M., Wagner, R., 1998.Zechstein evaporite deposition in the Central European Basin: cycles and stratigraphic sequences. Journal of Seismic Exploration 7, 201-218.

Piper, D.J.W., Pirmez, C., Manley, P.L., Long, D., Flood, R.D., Normark, W.R., Showers, W., 1997. Mass-transport deposits of the Amazon fan. In: Flood, R.D., Piper, D.J.W., Klaus, A., Peterson, L.C. (Eds.), Proceedings Ocean Drilling Project. Scientific Results 155, 109-146.

Pirmez, C., Hiscott, R.N., Kronen, J.K., 1997. Sandy turbidite successions at the base of channel-levee systems of the Amazon Fan revealed by FMS logs and cores: unravelling the facies architecture of large submarine fans. In: Flood, R. D., Klaus, A., Piper, D. J. W., Peterson, L. C. (Eds.), Proceedings of the Ocean Drilling Program Scientific Results 155, 7-22.

Playford, P.E., Hocking, R. M., Cockbain, A.E., 2009. Devonian Reef Complexes of the Canning Basin, Western Australia. Geological Survey of Western Australia Bulletin 145, 444 pp.
Playton, T.E., Janson, X., Kerans, C., 2008. Characterization, Variations, and Controls of Reefal Carbonate Foreslopes, Proceedings of the Annual Meeting of AAPG San Antonio.

Plint, A.G., 1988. Sharp-based shoreface sequences and "offshore bars" in the Cardium Formation of Alberta; their relationship to relative changes in sea level. In: Wilgus, C.K., Hastings, B.S., Kendall, C.G.St.C., Posamentier, H. W., Ross, C. A., Van Wagoner, J.C. (eds.), Sea Level Changes - An Integrated Approach. SEPM Special Publication 42, 357-370.

Plint, A. G., Nummedal, D., 2000. The falling stage systems tract: recognition and importance in sequence stratigraphic analysis. In: Hunt, D., Gawthorpe, R.L. (Eds.), Sedimentary Response to Forced Regression, vol.172. Geol. Soc. London Special Publication, pp.1-17.

Pomar, L., 1991. Reef geometries, erosion surfaces and high-frequency sea-level changes, upper Miocene reef complex, Mallorca, Spain. Sedimentology 38, 243-270.

Pomar, L., 1993. High-resolution Sequence Stratigraphy in Prograding Carbonates: Application to Seismic Interpretation. In: Loucks, B., Sarg, R. J. (Eds.), Carbonate Sequence Stratigraphy: Recent Advances and Applications, Chapter 15. A.A.P.G. Memoir 57, 545 pp.

Pomar, L., Kendall, C.G.St.C., 2008. Carbonate platform architecture; a response to hydrodynamics and evolving ecology. In: Lukasik, J., Simo, T. (Eds.): Controls on Carbonate Platform and Reef Development, SEPM Special Publication 89, 187-216.

Pomar, L., Ward, W.C., 1995. Sea-level changes, carbonate production and platform architecture: the Llucmajor Platform, Mallorca, Spain. In: Haq, B.U. (Ed.), Sequence Stratigraphy and Depositional Response to Eustatic, Tectonic and Climatic Forcing. Kluwer Academic Press, Dordrecht, p. 87-112.

Pomar, L., Ward, W.C., 1999. Reservoir-Scale Heterogeneity in Depositional Packages and Diagenetic Patterns on a Reef-Rimmed Platform, Upper Miocene, Mallorca, Spain. American Association of Petroleum Geologists Bulletin 83: 1759-1773.

Porebski, S.J., Steel, R.J., 2006. Deltas and sea-level change. Journal of Sedimentary Research 76, 390-403.

Posamentier, H.W., 2002. Ancient shelf ridges - A potentially significant component of the transgressive systems tract: Case study from offshore northwest Java. American Association of Petroleum Geologists Bulletin 86,1, 75106.

Posamentier, H. W., Allen, G. P., 1999. Siliciclastic sequence stratigraphy: concepts and applications. SEPM Concepts in Sedimentology and Paleontology no. 7, $210 \mathrm{pp}$.

Posamentier, H.W., Kolla, V., 2003. Seismic geomorphology and stratigraphy of depositional elements in deep-water settings. Journal of Sedimentary Research 73,3, 367-388.

Posamentier, H.W., Morris, W.R., 2000. Aspects of the stratal architecture of forced regressive deposits. In: Hunt, D., Gawthorpe, R.L. (eds.), Sedimentary Responses to Forced Regressions. Geological Society of London, Special Publication 172, 19-46. 
Posamentier, H.W., Vail, P.R., 1988. Eustatic controls on clastic deposition. II. Sequence and systems tract models. In: Wilgus, C.K., Hastings, B.S., Kendall, C.G.St.C., Posamentier, H.W., Ross, C.A., Van Wagoner, J.C. (Eds.), Sea Level Changes - An Integrated Approach. SEPM Special Publication 42, 125-154.

Posamentier, H.W., Walker, R.G., 2006. Deep-water turbidites and submarine fans. In: Posamentier, H.W., Walker, R.G. (eds.), Facies Models Revisited. Society for Sedimentary Geology (SEPM), Special Publication 84, 397-520.

Posamentier, H. W., Allen, G.P., James, D.P., 1992a. High resolution sequence stratigraphy - the East Coulee Delta, Alberta. Journal of Sedimentary Petrology 62,2, 310317.

Posamentier, H.W., Allen, G.P., James, D.P., Tesson, M., 1992b. Forced regressions in a sequence stratigraphic framework: concepts, examples, and exploration significance. American Association of Petroleum Geologists Bulletin 76, 1687-1709.

Posamentier, H.W., Jervey, M. T., Vail, P.R., 1988. Eustatic controls on clastic deposition. I. Conceptual framework. In: Wilgus, C.K., Hastings, B.S., Kendall, C.G.St.C., Posamentier, H.W., Ross, C.A., Van Wagoner, J.C. (Eds.), Sea Level Changes - An Integrated Approach. SEPM Special Publication 42, p. 110-124.

Pratt, B.R., Haidl, F.M., 2008. Microbial patch reefs in Upper Ordovician Red River strata, Williston Basin, Saskatchewan: Signal of heating in a deteriorating epeiric sea. In: Pratt, B.R., Holmden, C. (Eds.), Dynamics of Epeiric Seas. Geological Association of Canada, Special Publication 48, 303-340.

Rankey, E. C., Bachtel, S.L., Kaufman, J., 1999. Controls on stratigraphic architecture of icehouse mixed carbonatesiliciclastic systems: a case study from the Holder Formation (Pennsylvanian, Virgillian), Sacramento Mountains, New Mexico. In: Harris, P. M., Saller, A.H., Simo, J. A. (eds.), Advances in Sequence Stratigraphy: Application to Reservoirs Outcrops and Models. Soc. Econ. Petrol. Min. (Society for Sedimentary Geology) Spec. Publ. 63, 127-150.

Reid, S.K., Dorobek, S.L., 1993. Sequence stratigraphy and evolution of a progradational, foreland carbonate ramp, lower Mississippian Mission Canyon Formation and stratigraphic equivalents, Montana and Idaho. In: Loucks, R. G., Sarg, J.F. (eds.), Carbonate sequence stratigraphy Recent developments and applications. AAPG Memoir 57, 327-352.

Rudwick, M., 1996. Geological travel and theoretical innovation: the role of 'Liminal' experience. Social Studies of Sciences 26, 143-159.

Saller, A.H., Barton, J. W., Barton, R.E., 1989. Slope sedimentation associated with a vertically building shelf, Bone Spring Formation, Mescalero Escarpe Field, southeastern New Mexico. In: Crevello, P.G., Wilson, J.J., Sarg, J.F., Read, J.F. (eds.), Carbonate Platform and Basin Development. Soc. Econ. Petrol. Min. (Society for Sedimentary Geology) Spec. Publ. 44, 233-257.
Saller,A.H., Dickson, J.A.D., Rasbury, E.T., Ebato, T., 1999. Effects of long-term accommodation change on short-term cycles, Upper Palaeozoic platform limestones, West Texas. In: Harris, P.M., Saller, A.H., Simo, J. A. (eds.), Advances in Sequence Stratigraphy: Application to Reservoirs Outcrops and Models. Soc. Econ. Petrol. Min. (Society for Sedimentary Geology) Spec. Publ. 63, 227-246.

Sanders, D., Hofling, R., 2000. Carbonate deposition in mixed siliciclastic-carbonate environments on top of an orogenic wedge (Late Cretaceous, Northern Calcareous Alps, Austria). Sed. Geol. 137, 127-146.

Sandoval, J., O’Dogherty, L., Aguado, R., Bartolini, A., Bruchez, S., Bill, M., 2008. Aalenian carbon-isotope stratigraphy: calibration with ammonite, radiolarian and nannofossil events in the Western Tethys. Palaeogeogr. Palaeoclimatol. Palaeoecol. 267, 115-137.

Santiseban, C., Taberner, C., 1988. Sedimentary models of siliciclastic deposits and coral reef interactions. In: Doyle, L.J., Roberts, H.H. (eds.), Carbonate-Clastic Transitions. Elsevier, Developments in Sedimentology 42, 35-76, Amsterdam.

Sarg, J.F., 2001. The sequence stratigraphy, sedimentology, and economic importance of evaporite-carbonate transitions: a review. Sedimentary Geology 140, 9-42.

Saul, G., Naish, T.R., Abbott, S.T., Carter, R.M., 1999. Sedimentary cyclicity in the marine Pliocene-Pleistocene of the Wanganui Basin (New Zealand): sequence stratigraphic motifs characteristic of the past 2.5 m.y. Geological Society of America Bulletin 111, 524-537.

Scaturo, D.M., Strobel, J.S., Kendall, C.G.St. C., Wendte, J.C., Biswas, G., Bezdek, J., Cannon, R., 1989. Judy Creek: a case study of a two dimensional sediment deposition simulation. In: Wilson, J.L., Crevello, P., Read, F. (eds.), Controls on Carbonate Platform and Basin Development, SEPM Spec. Publ. 44, 64-76.

Schlager, W., 1992. Sedimentology and sequence stratigraphy of reefs and carbonate platforms. Continuing Education Course Note Series \#34, American Association of Petroleum Geologists, 71 pp.

Schlager, W., 2004. Fractal nature of stratigraphic sequences. Geology 32, 185-188.

Schlager, W., 2005. Carbonate Sedimentology and Sequence Stratigraphy. SEPM Concepts in Sedimentology and $\mathrm{Pa}-$ leontology \#8, 200 pp.

Schlager, W., 2010. Ordered hierarchy versus scale invariance in sequence stratigraphy. International Journal of Earth Sciences 99, S139-S151.

Schlager, W., Reijmer, J. J. G., Droxler, A., 1994. Highstand shedding of carbonate platforms. Jour. of Sed. Res., B64, 270-281.

Schumm, S.A., 1993. River response to baselevel change: implications for sequence stratigraphy. Journal of Geology 101, 279-294.

Schwarzacher, A., 2000. Repetition and cycles in stratigraphy. Earth-Science Reviews 50, 51-75.

Shanley, K. W., McCabe, P. J., 1994. Perspectives on the sequence stratigraphy of continental strata. American Association of Petroleum Geologists Bulletin 78, 544-568. 
Sharland, P.R., Archer, R., Casey, D. M., Davies, R. B., Hall, S.H., Heward, A.P., Horbury, A.D., Simmons, M.D., 2001. Arabian Plate Sequence Stratigraphy. GeoArabia Special Publication 2, Gulf PetroLink, Bahrain, 371 pp.

Simo, A., 1989. Upper Cretaceous platform to basin depositional sequence development, Tremp Basin, south central Pyrenees, Spain. In: Crevello, P. G., Wilson, J.J., Sarg, J.F., Read, J.F. (eds.), Carbonate Platform and Basin Development. Soc. Econ. Petrol. Min. Spec. Publ. 44, 233-257.

Sixsmith, P. J., Flint, S. S., Wickens, H. de V., Johnson, S. D. 2004. Anatomy and stratigraphic development of a basin floor turbidite systemin the Laingsburg formation, main Karoo basin, South Africa. Journal of Sedimentary Research 74, 239-254.

Sloss, L.L., 1963. Sequences in the cratonic interior of North America. Geological Society of America Bulletin 74, 93-114.

Sloss, L.L., Krumbein, W.C., Dapples, E.C., 1949. Integrated facies analysis. In: Longwell, C.R. (ed.), Sedimentary Facies in Geologic History. Geological Society of America Memoir 39, 91-124.

Slowakiewicz, M., Mikolajewski, Z., 2009. Sequence stratigraphy of the Upper Permian Zechstein Main Dolomite carbonates in western Poland: a new approach. Journal Petroleum Geology 32, 215-234.

Smith, L. B., Read, J.F., 2000. Rapid onset of late Palaeozoic glaciation on Gondwana: evidence from Upper Mississippian strata of the Mid-continent, U.S.A. Geology 28, 279-282.

Smith, L. B., Read, J. F., 2001. Discrimination of local and global effects on Upper Mississippian stratigraphy, Illinois Basin, U.S.A. Journal of Sedimantary Research 71, 985-1002.

Smith, L.B., Eberli, G.P., Sonnenfeld, M.D., 2003. Sequence-stratigraphic and paleogeographic distribution of reservoir-quality dolomite, Madison Formation, Wyoming and Montana. In: Grammer, G.M., Eberli, G.P., Harris, P.M. (eds.), Integration of outcrop and modern analogs in reservoir modeling. - AAPG Memoir 80, 94-118.

Soreghan, G.S., 1997. Walther's law, climate change and upper Paleozoic cyclostratigraphy in the ancestral Rocky Mountains. Journal of Sedimnetary Research 67, 10011004.

Southgate, P.N., Kennard, J.M., Jackson, M.J., O’Brien, P.E., Sexton, M. J., 1993. Reciprocal lowstand clastic and highstand carbonate sedimentation, subsurface Devonian Reef Complex, Canning Basin, Western Australia. In: Loucks, R.G., Sarg, J.F. (eds.), Carbonate Sequence Stratigraphy. AAPG Memoir 57, 157-179.

Spence, G.H., Tucker, M.E., 1997. Genesis of limestone megabreccias and their significance in carbonate sequence stratigraphic models: a review. Sedimentary Geology 112, 163-193.

Spence, G.H., Tucker, M.E., 2007. A proposed integrated multi-signature model for peritidal cycles in carbonates Journal of Sedimentary Research 77, 797-808.

Sprague, A.R., Patterson, P.E., Hill, R.E., Jones, C.R., Campion, K.M., Van Wagoner, J.C., Sullivan, M.D.
Larue, D.K., Feldman, H.R., Demko, T.M., Wellner, R.W., Geslin, J.K., 2002. The Physical Stratigraphy of Fluvial Strata: A Hierarchical Approach to the Analysis of Genetically Related Stratigraphic Elements for Improved Reservoir Prediction. (Abstract) AAPG Annual Meeting. Sprague, A.R., Sullivan, M.D., Campion, K.M., Jensen, G.N., Goulding, F. J., Garfield, T.R., Sickafoose, D.K., Rossen, C., Jennette, D.C., Beaubouef, R. T., Abreu, V., Ardill, J., Porter, M.L., Zelt, F.B., 2003. The Physical Stratigraphy of Deep-Water Strata: A Hierarchical Approach to the Analysis of Genetically Related Stratigraphic Elements for Improved Reservoir Prediction. AAPG Bulletin, (Abstract) AAPG Annual Meeting, 87, $10 \mathrm{p}$.

Sprague, A.R., Patterson, P.E., Sullivan, M.D., Campion, K.M., Jones, C.R., Garfield, T.R., Sickafoose, D.K., Jennette, D.C., Jensen, G. N., Beaubouef, R.T., Goulding, F. J., Van Wagoner, J.C., Wellner, R. W., Larue, D. K., Rossen, C., Hill, R.E., Geslin, J.K., Feldman, H.R., Demko, T.M., Abreu, V., Zelt, F.B., Ardill, J., Porter, M.L., 2004. Physical Stratigraphy of Clastic Strata: A Hierarchical Approach to the Analysis of Genetically Related Stratigraphic Elements for Improved Reservoir Prediction. Abstract, AAPG 2003-04 Distinguished lecturer Tour Information.

Steel, R. J., Olsen, T., 2002. Clinoforms, clinoform trajectories and deepwater sands. In: Armentrout, J.M., Rosen, N.C. (eds.), Sequence Stratigraphic Models for Exploration and Production: Evolving Methodology, Emerging Models and Application Histories. Proceeding of the $22^{\text {nd }}$ Annual Bob F. Perkins Research Conference. Gulf Coast Section, Society of Economic Paleontologists and Mineralogists (GCS-SEPM), 367-381.

Steuber, T., Rauch, M., Masse, J.-P., Graaf, J., Malkoc, M., 2005. Low-latitude seasonality of Cretaceous temperatures in warm and cold episodes. Nature 437, 1341-1344.

Strasser, A., 2007. Astronomical time scale for the Middle Oxfordian to Late Kimmeridgian in the Swiss and French Jura Mountains. Swiss J. Geosci. 100, 407-429.

Strasser, A., Hilgen, F. J., Heckel, P.H., 2006. Cyclostratigraphy - concepts, definitions, and applications. Newsletters on Stratigraphy 42, 75-114.

Strasser, A., Hillgärtner, H., Hug, W., Pittet, B., 2000. Thirdorder depositional sequences reflecting Milankovitch cyclicity. Terra Nova 12, 303-311.

Strasser, A., Hillgärtner, H., Pasquier, J.-B., 2004. Cyclostratigraphic timing of sedimentary processes: an example from the Berriasian of the Swiss and French Jura Mountains. SEPM Spec. Publ. 81, 135-151.

Strasser, A., Pittet, B., Hillgärtner, H., Pasquier, J.-B., 1999. Depositional sequences in shallow carbonate-dominated sedimentary systems: concepts for a high-resolution analysis. Sedimentary Geology 128, 201-221.

Strohmenger, C., Voight, E., Zimdars, J., 1996. Sequence stratigraphy and cyclic development of Basal Zechstein carbonate-evaporite deposits with emphasis on Zechstein 2 off-platform carbonates (Upper Permian, Northeast Germany). Sedimentary Geology 102, 33-54. 
Swift, D.J.P., 1975. Barrier-island genesis: evidence from the central Atlantic shelf, eastern U.S.A. Sedimentary Geology 14, 1-43.

Taylor, J.C.M., 1990. Upper Permian-Zechstein. In: Glennie, K.W. (Ed.), Introduction to the Petroleum Geology of the North Sea. Blackwell Science, Oxford, p. 153-190.

Thomas, R. G., Smith, D. G., Wood, J.M., Visser, J., Calverley-Range, E. A., Koster, E. H., 1987. Inclined heterolithic stratification - terminology, description, interpretation and significance. Sedimentary Geology 53, 123-179.

Tinker, S.W., 1998. Shelf-to-basin facies distributions and sequence stratigraphy of a steep-rimmed carbonate margin: Capitan depositional system, McKittrick Canyon, New Mexico and Texas. Journal of Sedimentary Research 68,6, 1146-1174.

Tucker, M.E., 1991. Sequence stratigraphy of carbonate evaporite basins, models and application to the Upper Permian (Zechstein of northeast England and adjoining North Sea. Journal of the Geological Society 148, 10191036.

Tucker, M.E., 2003. Mixed clastic carbonate successions: Quaternary of Egypt, Mid Carboniferous, NE England. Geologica Croatica 56, 19-37.

Tucker, M.E., Garland, J., 2010. High-frequency cycles and their sequence stratigraphic context: orbital forcing and tectonic controls on Devonian cyclicity, Belgium. Geologica Belgica 13/3, 213-240.

Tucker, M.E., Gallagher, J., Leng, M., 2009. Are beds millennial-scale cycles? An example from the Carboniferous of NE England. Sedimentary Geology 214, 19-34.

Vail, P.R., 1987. Seismic stratigraphy interpretation procedure. In: Bally, A. W. (Ed.), Atlas of Seismic Stratigraphy, vol.27. American Association of Petroleum Geologists Studies in Geology, p. 1-10.

Vail, P.R., Mitchum, R.M.Jr., Thompson, S., III, 1977. Seismic stratigraphy and global changes of sea level, part four: global cycles of relative changes of sea level. American Association of Petroleum Geologists Memoir 26, 83-98.

Vail, P.R., Audemard, F., Bowman, S.A., Eisner, P.N., Perez-Cruz, C., 1991. The stratigraphic signatures of tectonics, eustasy and sedimentology - an overview. In: Einsele, G., Ricken, W., Seilacher, A. (eds), Cycles and Events in Stratigraphy. Springer-Verlag, p. 617-659.

Van Buchem, F.S.P., Razin, P., Homewood, P.W., Oterdoom, W. H., Philip, J., 2002. Stratigraphic Organization of Carbonate Ramps and Organic-Rich Intrashelf Basins: Natih Formation (Middle Cretaceous) of Northern Oman. AAPG Bulletin 86,1, 21-53.

Van Buchem, F. S.P., Pittet, B., Hillgarten, H., Grötsch, J., AlMansouri, A., Billing, I.M., van Steenwinkel, M., Droste, H.H.J., Oterdoom, H., 2003. High-Resolution Sequence Stratigraphic Architecture of Barremian-Aptian Carbonate Systems in Northern Oman and the United Arab Emirates (Kharaib and Shu'aiba Formations). GeoArabia 7,3, 461500.

Van den Belt, F.J.G., de Boer, P.L., 2007. A shallow-basin model for 'saline giants' based on isostasy-driven subsi- dence. In: Nichols, G., Williams, E., Paola, C. (Eds.), Sedimentary Processes, Environments and Basins. International Association of Sedimentologists Special Publication 38, 241-252.

Vandenberghe, J., 1993. Changing fluvial processes under changing periglacial conditions. Z. Geomorph. N.F. 88, 17-28.

Vandenberghe, J., Kasse, C., Bohnke, S., Kozarski, S., 1994. Climate-related river activity at the Weichselian-Holocene transition: a comparative study of the Warta and Maas rivers. Terra Nova 6, 476-485.

Van der Merwe, W.C., Flint, S.S., Hodgson, D. M., 2010. Sequence stratigraphy of an argillaceous, deepwater basin-plain succession: Vischkuil Formation (Permian), Karoo Basin, South Africa. Marine and Petroleum Geology 27, 321-333.

Van Wagoner, J.C., 1995. Sequence Stratigraphy and Marine to Nonmarine Facies Architecture of Foreland Basin Strata, Book Cliffs, Utah, U.S.A. In: Van Wagoner, J.C., Bertram, G. T. (Eds.), Sequence Stratigraphy of Foreland Basin Deposits. American Association Petroleum Geologists Memoir 64, 137-223.

Van Wagoner, J.C., Mitchum, R.M., Posamentier, H. W., Vail, P.R., 1987. An overview of sequence stratigraphy and key definitions. In: Bally, A. W. (Ed.), Atlas of Seismic Stratigraphy, volume 1. AAPG Studies in Geology 27, 11-14.

Van Wagoner, J.C., Posamentier, H.W., Mitchum, R.M., Vail, P. R., Sarg, J.F., Loutit, T.S., Hardenbol, J., 1988. An overview of sequence stratigraphy and key definitions. In: Wilgus, C.K., Hastings, B.S., Kendall, C.G. St.C., Posamentier, H.W., Ross, C.A., Van Wagoner, J.C. (Eds.), Sea Level Changes - An Integrated ApproachSEPM Special Publication 42, 39-45.

Van Wagoner, J.C., Mitchum Jr., R.M., Campion, K.M., Rahmanian, V.D., 1990. Siliciclastic sequence stratigraphy in well logs, core, and outcrops: concepts for highresolution correlation of time and facies. American Association of Petroleum Geologists Methods in Exploration Series 7, $55 \mathrm{pp}$.

Warren, J., 2006. Evaporites: Sediments, Resources, Hydrocarbons. Springer-Verlag, Berlin.

Weimer, P., 1991. Seismic facies, characteristics, and variations in channel evolution, Mississippi Fan (Plio/Pleistocene), Gulf of Mexico. In: Weimer, P., Link, M.H. (eds.), Seismic facies and sedimentary processes of submarine fans and turbidite systems. Springer-Verlag, New York, p. 323-347.

Weimer, P., Slatt, R. M., 2007. Petroleum geology of deepwater settings. AAPG Studies in Geology, vol.57, American Association of Petroleum Geologists, Tulsa, 816 pp.

Weimer, R.J., 1966. Time-stratigraphic analysis and petroleum accumulations, Patrick Draw field, Sweetwater County, Wyoming. Bulletin of the American Association of Petroleum Geologists 50,10, 2150-2175.

Weissert, H., Mohr, H., 1996. Late Jurassic climate and its impact on carbon cycling. Palaeogeology, Palaeoclimatology, Palaeoecology 122, 27-43. 
Weissert, H., Joachimski, M., Sarnthein, M., 2008. Chemostratigraphy. Newsletters on Stratigraphy 42, 145-179.

Wildi, W., Funk, H., Loup, B., Amato, E., Huggenberger, P., 1989. Mesozoic subsidence history of the European marginal shelves of the Alpine Tethys (Helvetic realm, Swiss Plateau and Jura). Eclogae Geol. Helv. 82, 817-840.

Wilkinson, B.H., Merrill, G.K., Kivett, S.J., 2003. Stratal order in Pennsylvanian cyclothems. Bulletin Geological Society of America 115, 1068-1087.

Willis, A.J., 2000. Tectonic control of nested sequence architecture in the Sego Sandstone, Neslen Formation, and Upper Castlegate Sandstone (Upper Cretaceous), Sevier Foreland Basin, Utah, USA. Sedimentary Geology 136, 277-317.

Wilson, M.E. J., Lockier, S. W., 2002. Siliciclastic and volcaniclastic influences on equatorial carbonates: insights from the Neogene of Indonesia. Sedimentology 49, 583601.

Winker, C.D., Booth, J.R., 2000. Sedimentary dynamics of the salt-dominated continental slope, Gulf of Mexico: integration of observations from the sea floor, near-surface and deep subsurface. In: Weimer, P., Slatt, R. M., Coleman, J., Rosen, N.C., Nelson, H., Bouma, A. H., Styzen,
M. J., Lawrence, D.T. (Eds.), Deepwater Reservoirs of the World. Gulf Coast Society of the Society of Economic Paleontologists and Mineralogists Foundation, 20th Annual Research Conference, p. 1059-1086.

Wright, V.P., Marriott, S.B., 1993. The sequence stratigraphy of fluvial depositional systems: the role of floodplain sediment storage. Sedimentary Geology 86, 203-210.

Wright, V.P., Vanstone, S. D., 2001. Onset of late Palaeozoic glacio-eustasy and the evolving climates of low latitudes: a synthesis of current understanding. Journal Geological Society London 158, 579-582.

Yoshida, S., 2000. Sequence stratigraphy and facies architecture of the upper Blackhawk Formation and the Lower Castlegate Sandstone (Upper Cretaceous), Book Cliffs, Utah, USA. Sedimentary Geology 136, 239-276.

Yoshida, S., Willis, A., Miall, A.D., 1996. Tectonic control of nested sequence architecture in the Castlegate Sandstone (Upper Cretaceous), Book Cliffs, Utah. Journal of Sedimentary Research 66, 737-748. 